\title{
أثر ممارسة السرد القصصي لتحسين اللغة لدي أطفال الروضة الاضطربين لغوياً
}

\author{
! إعراد \\ د / سعد عبد المطلب عبد الغفار \\ مدرس علم النفس. كعليتشرياض الأطفال \\ جامعتَالمنصورة
}

المجلت العلميت لكليت رياض الأطفالـ جامعت المنصورة

المجلد الثالث ـالعدد الثالث

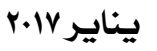




\section{أثر ممارسة السرد القصصي لتحسين اللغة لدي ألدال الروضة المضطربين لغوياً}

د / سعد عبد المطلب عبد الغفار **

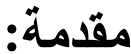

القصة من أقدر الأساليب الأدبية التي تعمل على تتمية الفضائل في النفس،

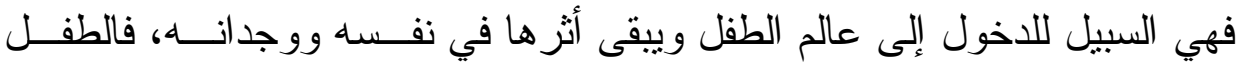

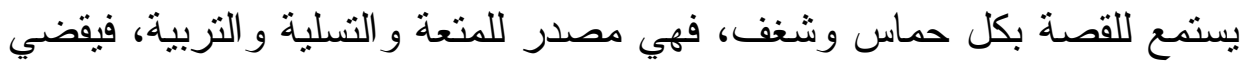
وقتاً ممتعاً في سماعها ومتابعة أحداثها؛ وبذلك تكون للقصنة أثر بالغ فــي حيــاة

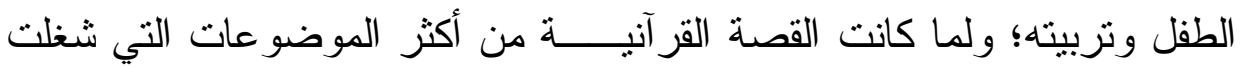

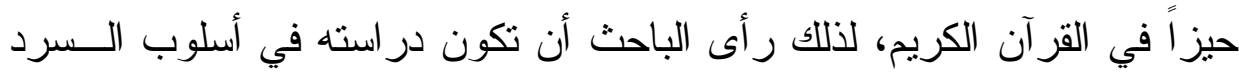

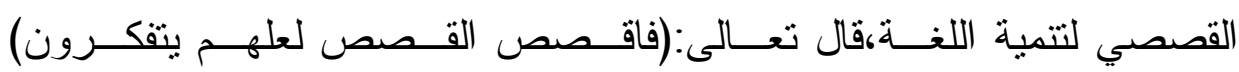
(الأعر اف: (IVT)

ويمكن توظيف القصة كأداة تدريسية تساعد فى بناء مهــارات الأطفــال،

وتعزز فهمهم، وتوضح نتائج التجارب الميدانية الأثر الإيجابي لفاعلية اســـتخدام

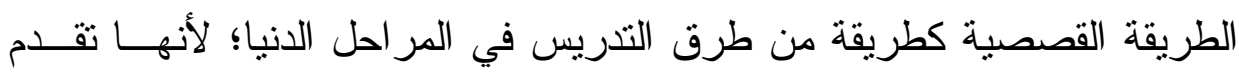

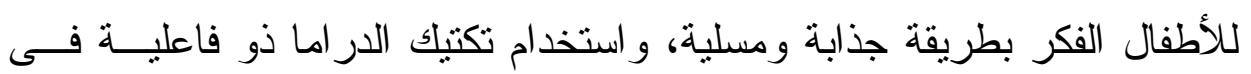

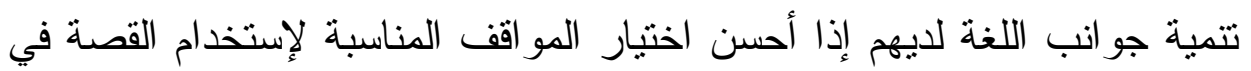

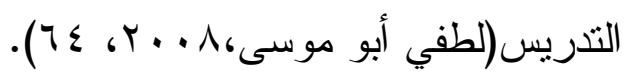

** مدرس علم النفسـ كليت رياض الأطفالـ جامعت المنصورة

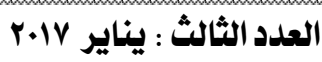

$|r|$

المجلد الثالث 
وتعد القصة من أحب الوان الادب بالنسبة للأطفال، لذلك فهي تعد عـاملا

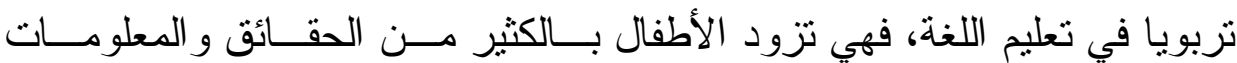

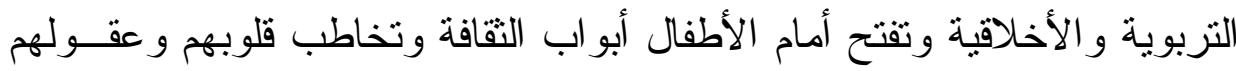

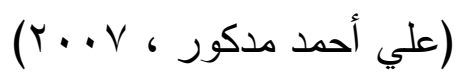

لذا؛ فإن الباحث اتجه إلى استخدام السرد القصصي مــع الأطفــال الـــين

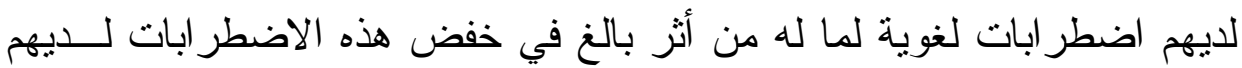

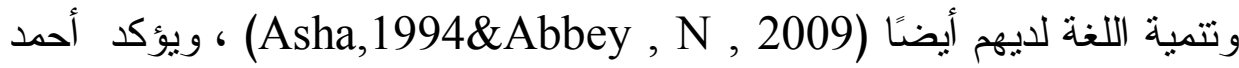

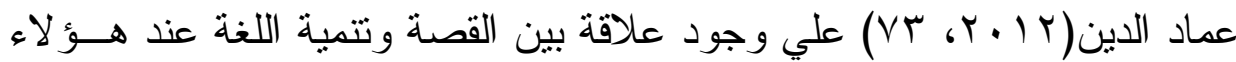

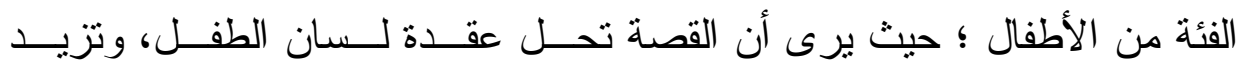

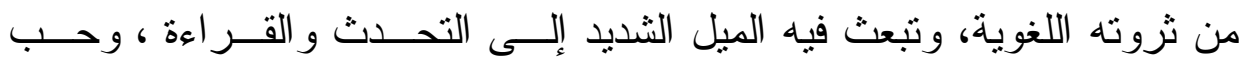

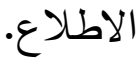

كما أن للقصة دورًا مهمًا في اكتساب الطفل للمفردات اللغويــة الـــليمة، وتصحيح النطق اللغوي؛ فيصبح أكثر تحكماً في مخارج الحروف و أكثر اتقانـاً

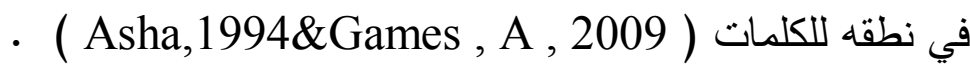

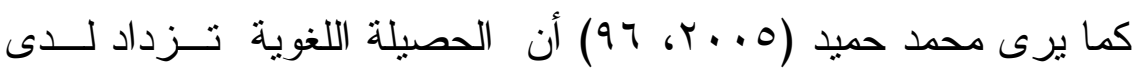
الطفل من خلال كلمات القصة وعبار ات اللغة العربية، وتعويده النطق الـسليم، فعندما يكتسب الطفل المفردات اللغوية يتكون لديه محصول لغوي مـن خلالـــهـ

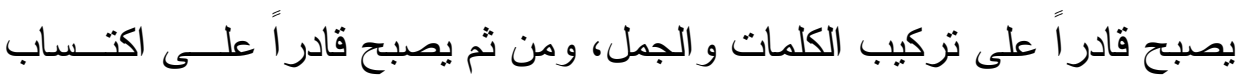

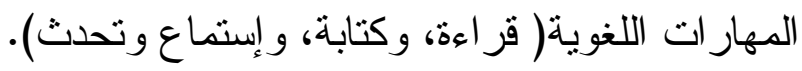

و الاهتمام بخفض اضطر ابات اللغة وتتميتها لدى الأطفال من أهم المناحي التي يجب التزكيز عليها في البحوث و الدراسات، فالطفل الذي لايستطيع التعبير 
عن نفسه و عما يدور بينه وبين الآخرين، و التو اصل معهم بسبب اضطر اب نطقه Demirel, m, ) قدؤدي به إلى العديد من المشكلات النفسية و السلوكية، ويرى (2010, 64 أن من نتائج اضطر ابات اللغة عامة وخاصة اضطر ابات النطــق الخجل و الإحباط، و الانطو اء، وتصرفات أخرى غيــر ســوية مثــلـ: الــسلوك العدو اني تجاه الآخرين، أو النشاط الز ائد، و السلوك الانسحابي وذللك لما يتعرض له من سخرية و استهز اء من الأطفال الآخرين. فإعاقة عملية التو اصــل يترتــبـ عليها مشكلات اجتماعية ونفسية للطفل تؤثر فى نموه اللغوي، ونمــوه النفـسي و الاجتماعي أيضًا منل الشعور بالرفض من الآخرين ، و الانطو اء ، و الانسحاب من المو اقف الاجتماعية ، و الإحباط ، و الثعور بالفشّل ، و النقص او الــذنب أو العدوانية نحو الذات أو نحو الآخرين ، و العمل علي حماية أنفسهم بطريقة مبالغ

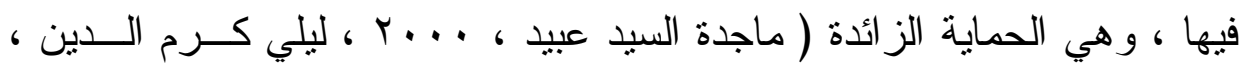
- (William\&Orlee,2003,Laura,M , 2007 ، r. . s و أثنار سميث(Smith,2004) إلى أن هناك إثشار ات و علامــات تـسـاعدنا على التعرف على وجود اضطر ابات لغوية لدى الأطفال، حيث بظهرون عـدم القدرة على اتباع التعليمات اللفظية، وعــدم القــدرة علــى مطابقــة الحــروف بالأصوات، وحصيلة من المفردات غير الو اضحة بالإضافة إلـى قـى قصور فــي تكوين المفاهيم اللفظية، وصعوبة في إيصال الرسائل للآخرين، وكذلك صـــوبة في التعبير عن الحاجات الثخصية، وهذه العلامات بمجملها تعكس اضــطر ابات مكونات اللغة.

وتظهر الاضطر ابات في المستوى الصوتي في عدم قدرة الطفـلـل علــى إدر الك الفروق بين الفونيمات المنتوعة، و إنتاجها فإن استخدام اللغة سوف يكــون فيه خلل و اضـح، أما اضطر ابات المستوى الصرفي تظهر في نهايــة الكلمـات 
و الكلمات المشددة و غيرها. أما المستوى النحوي فيظهر في قدرته على تكــوين

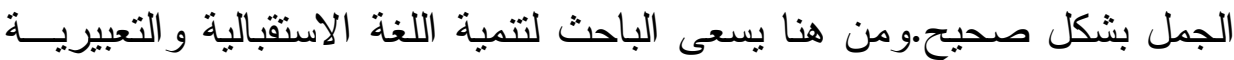

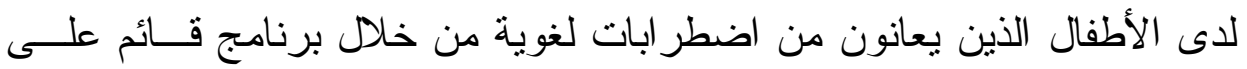
إستر اتيجية السرد القصصي.

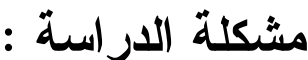

إن المشكلات اللغوية اذا تركــت دون معالجــة وتــصحيح تــؤدي الــي مضاعفات و أثار نفسية سلبية ، قد تعوق بدرجة كبيرة القدرة علي نمو شخـصية

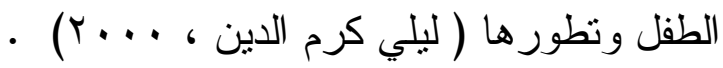

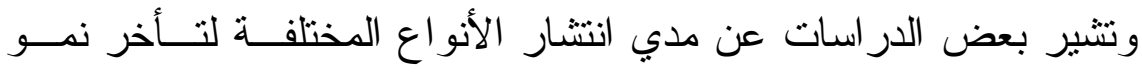

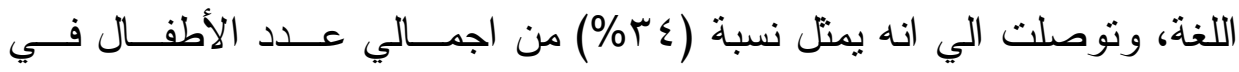

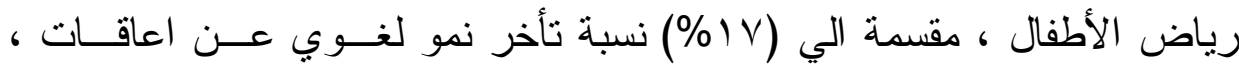

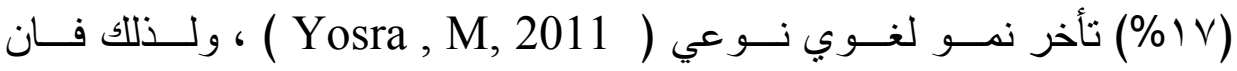
تأخر اللغة بالنسبة للأطفال في مرحلة الطفولة المبكرة مــن المـــكلات التــي

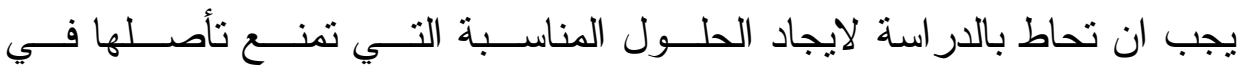

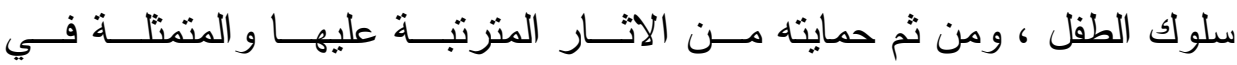

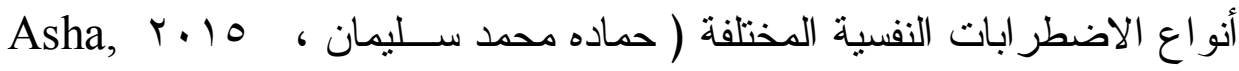
. (1994,

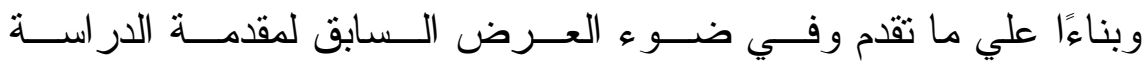

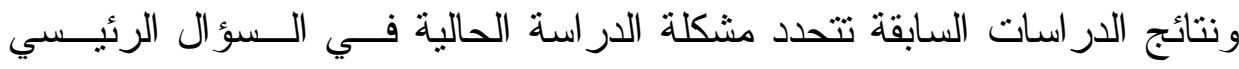

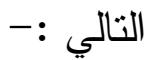


ما أثز برنامج قائم على استر اتيجية السرد القصصي لتتمية اللغــة لــدى عينة من الأطفال المضطربين لغوياً؟ لرئ وينبثق من هذا السؤال الرئيسي الأسئلة التالية :هل توجد فروق دالة إحصائيا في متوسط درجات الاضــــر اب اللغـــوي

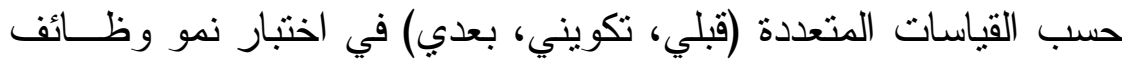
اللغة لاى الأطفال المضطربين لغويًا؟

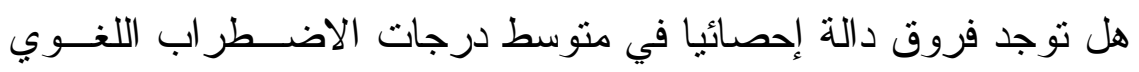

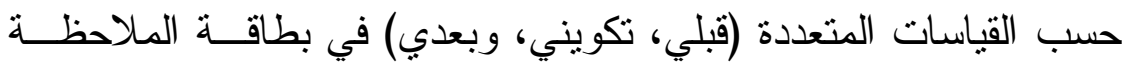

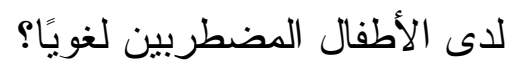

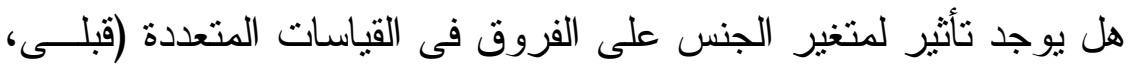

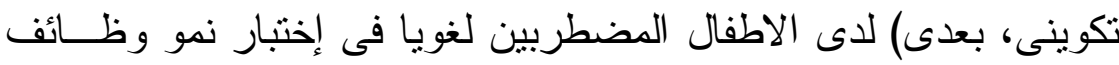
اللغه؟ هل نوجد مجموعة من العوامل الدينامية المسئولة عن الاستفادة أو عـدم

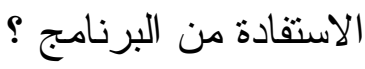

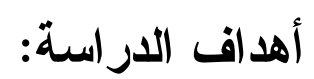

تهدف الدراسه الحاليه الي التعرف علي ظاهرة الاضطر اب اللغوي و القاء

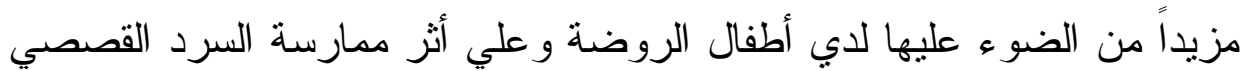

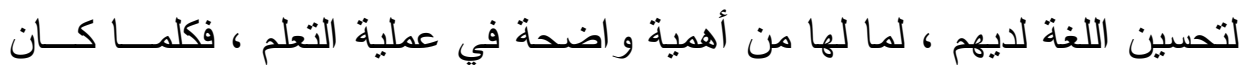

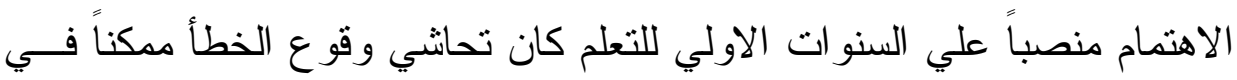

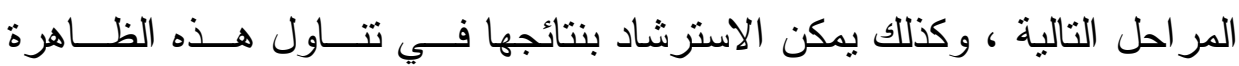

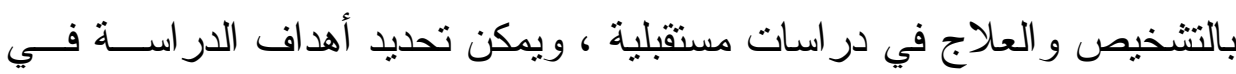

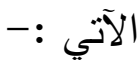


1. التحقق من أثر برنامج قائم على السرد القصصي لتنمية اللغة الاسـتنقبالية

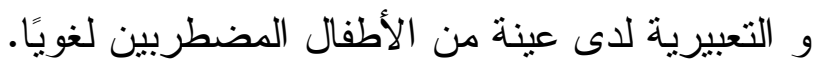

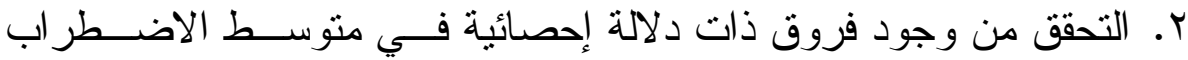
اللغوي حسب القياسات المتعددة (قبلي_تكويني_بعدي) فى اختبار نــــ وظائف اللغة لدى الأطفال المضطربين لغويًا.

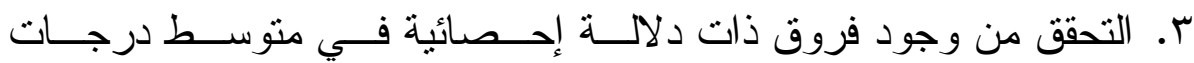
الاضطر اب اللغوي حسب القياسات المتعددة (قبلي_تكويني_بعدي) فــي بطاقة الملاحظة لاى الأطفال المضطربين لغويًا.

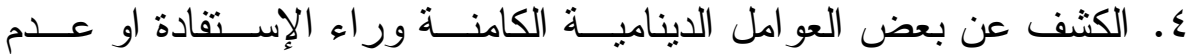

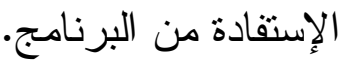

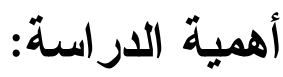

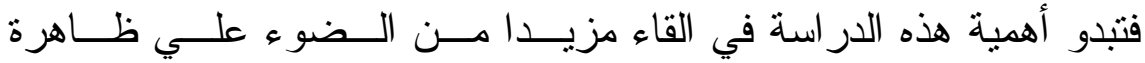

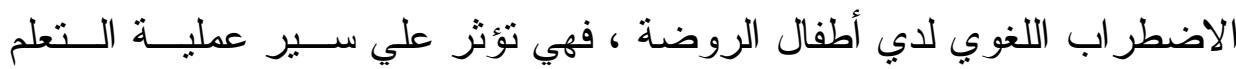

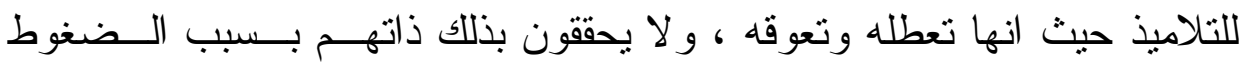
الانفعالية الناتجة عن الإحساس بالعجز و عدم القدرة علي المتابعة وغيرها مسن

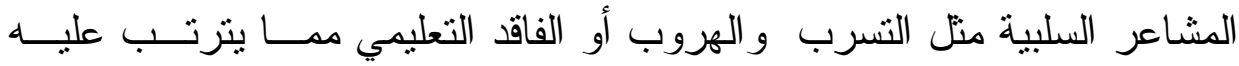
الكثير من ضعف المهار ات التعليمية و الحياتية و اليدوية البسيطة وأيضا الــضياع

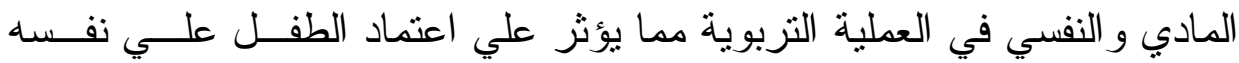

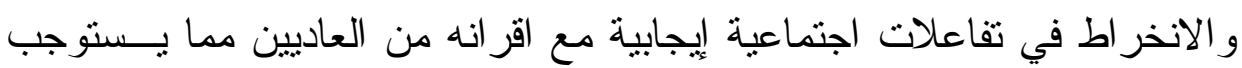
الاهتمام المبكر لهذه الظاهرة الخطيرة و التصدي لها للقضـاء عليها أو الحد مـن لهن

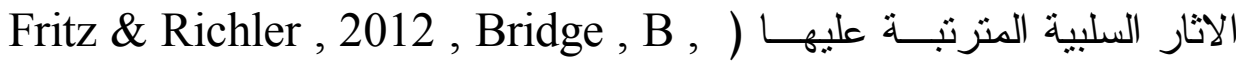

( 2010 , Laura , M , 2007 
ويمكن تحديد أهمية الار اسة النظرية والتطبيقية على التحو التالي:

أولاً: الأهمية النظرية:

ا. توجيه الاهتمام لهذه الفئة من الأطفال المضطربين لغويًا، وتقديم التأصــيل

النظري لمشكلة الاضطر اب اللغوي، و التي من شأنها أن تؤدي إلى معاناة الطفل من بعض المشكلات الناتجة عن سوء التو اصل بينه وبين المحيطين

بـ

r. تكمن أهمية الدر اسة الحالية في أهمية الجانب الذى تتصدي لدر استه؛ حيث

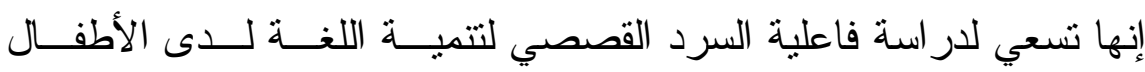
المضطربين لغوياً؛ حيث تؤدي منل هذه البر امج بالنـسبة للأطفــال دوراً بارزاً في بناء حصيلة لغوية كبيرة من أجل إنتاج وفهم اللغة، وهو جانــبـ

$$
\text { يبدو على قدر كبير من الأهمية. }
$$

r. إنها تدرس مرحلة مهمة من مر احل النمو الإنساني، وهي مرحلة الطفولـــة

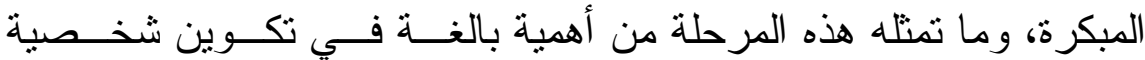

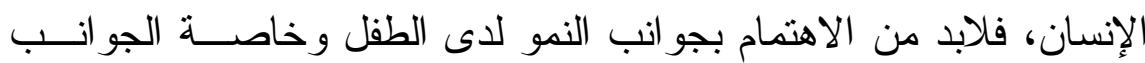
المعرفية و اللغوية لديه و التى تمكنه من التو اصل مع بيئته وتكوين مفهــوم إيجابي عن نفسه و الارتقاء بها و النهوض بالأطفال؛ لأنهم شباب المسـتقبل

$$
\text { وحاملي لو اء التقدم و الازدهار . }
$$

ـ. تسهم هذه الدر اسة في إلقــاء المزيــد مــن الــضوء علــى موضــوع الاضطر اب اللغوي من خلال الإطار النظري و الدر اسات السابقة ونتــائج

$$
\text { الدر اسة. }
$$




\section{ثانيًا : الأهمية التطبيقية:}

1. التصدي لمشكلة الاضطر اب اللغوي لدى الأطفال في عمر مبكر قد يساعد

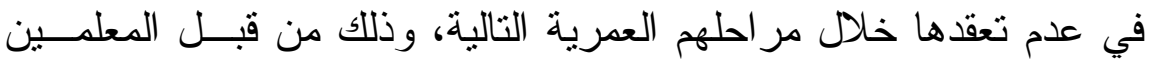
و القائمين على أمر نربية ور عاية هؤ لاء الأطفال.

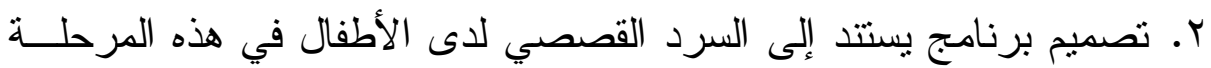

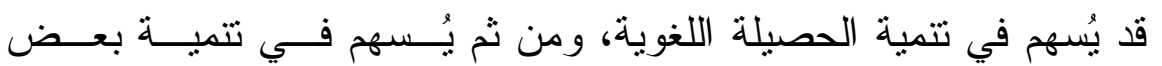

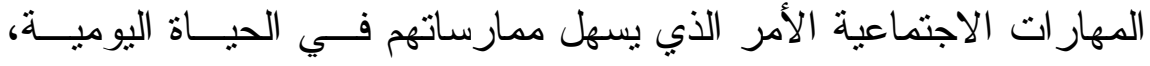
ويزيد من تفاعلهم في المجتمع ومع الآخرين. r. تقديم التوصيات و المقترحات و الإرشادات للو الــدين و المهتهـين بــشئون

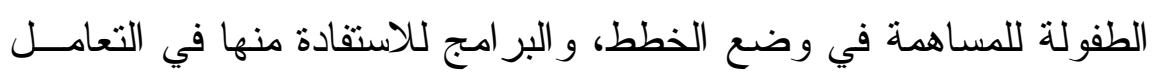
مع الأطفال المضطربين لغويًا، و التىى تعتمد على السرد القصصي. مفاهيم الار اسة:

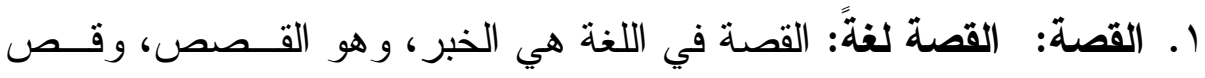

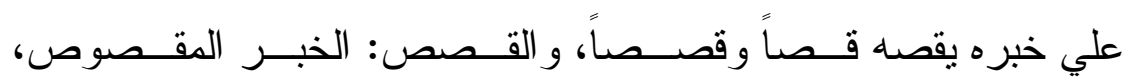
و القصص: جمع القصة التي تكتب.

أما القصة اصطلاحاً فتعرف بأنها: عمل فنــي يمـنح الـشعور بالمتعــة

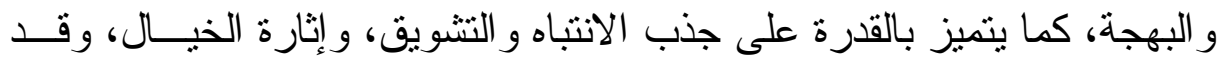

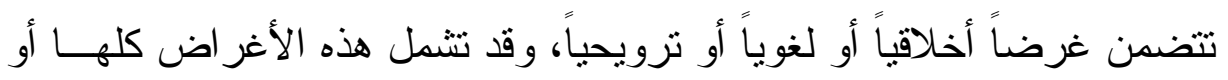
بعضها. 
وتهدف القصة الي تدريب الطفل علــي مهــار ات التو اصــلـ و الحــديث

و الانصات ، وتتمية الطفل لغويا من خلال تدريبه علي التعبير عن ذاته وتتميــة قاموسه اللغوي ، وتتمية الطفل معرفيا بإثز اء معلوماته حــول العــالم الــو اقعي و المتخيل ، و اكسابه كثير ا من القيم الذاتية ، و الآداب و السلوك الإيجابي ، و اثز اء وزيادة رصيد الطفل اللغوي ، وتعلمه وتعوده حسن الاسنماع و التلقى والاصغاء

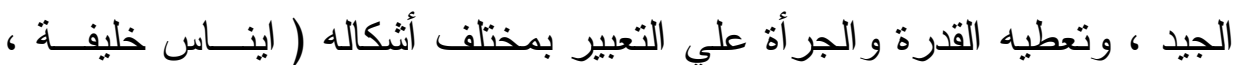
$\cdot(r \cdot r$

\section{التعريف الإجرائي للإة:}

عرفت القصة إجر ائياً في هذه الدر اسة بأنها: كل ما يكتب ويقال للأطفــال لتسليتهم، وتوجيههم، وتتمية قدر اتهم، و إكسابهم قيم مرغوب فيها، وشغل أوقـات فر اغهم بما هو مفيد وممتع بالنسبة لهم.

Y. السرد القصصي: وتعرفه أماني أبو شمالة(9 . . Y، 0) بأنه: "حكاية أحداث

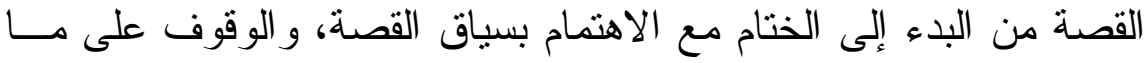
ورد فيها من شخصيات، و أحداث، ومواقف، وتحليل مــا تـضمنته مــن دلالات نفسية، و اجتماعية، وتربوية، وسياسية." التعريف الإجر ائي للسرد القصصي: هو منهج من مناهج التــأليف فــــي

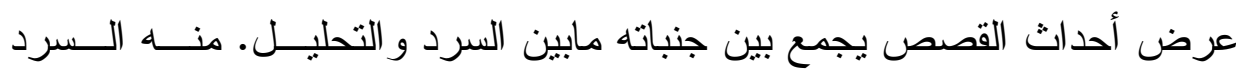
التحليلي للقصة الذي يعرض مجموعة من الأحداث المتر ابطة للقصة من البــدء

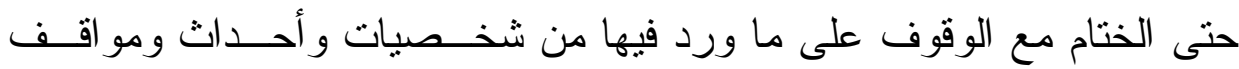
وتحليل لما تضمنته من دلالات. 
r. تنمية اللغة: تعرف على أنها تحسين مستوى الأداء اللغوي للأطفال كاتباع

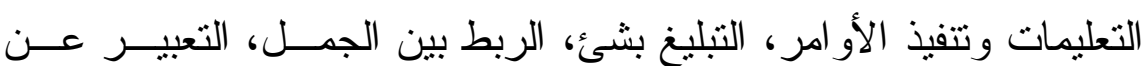

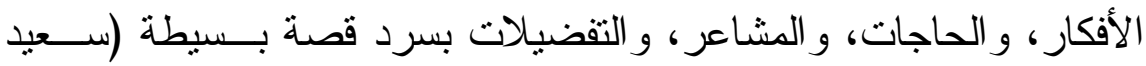

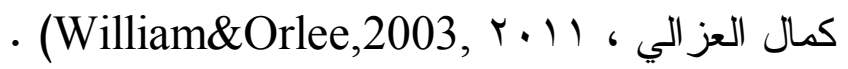

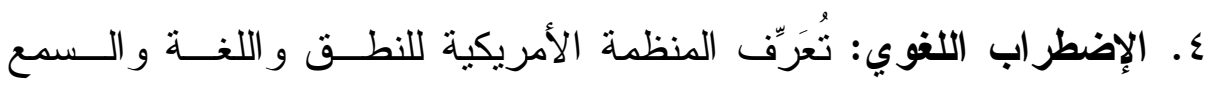
(ASHA) الاضطر ابات اللغوية (Language Disorders) بأنها " إعاقة

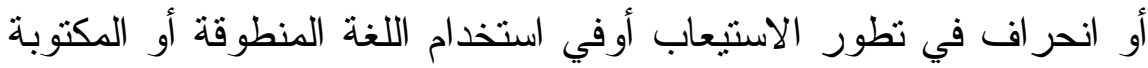

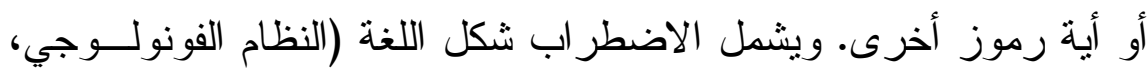

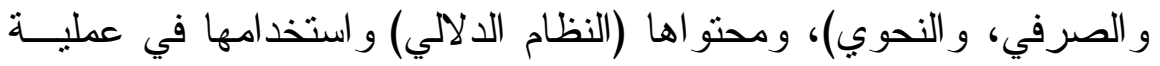

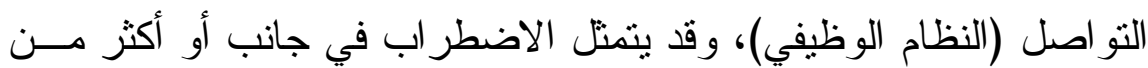
هذه الجو انب الثلاثة للغة (Yosra , M , 2011 ) حدود الار اسة : تتحدد نتائج الدر اسة بالحــدود الزمانيــة و المكانيـــة و البـشرية و الأدوات

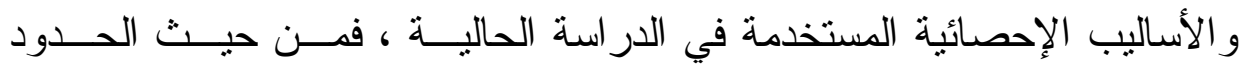

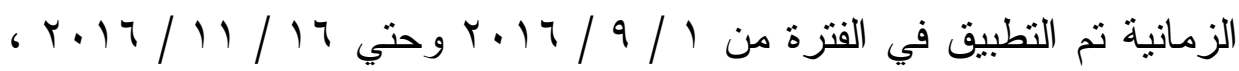
و المكانية نم إجر اء الدراسة في روضة هابي كيدز - بمدينة المنصورة (دقهلية)،

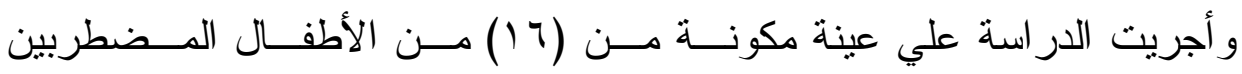

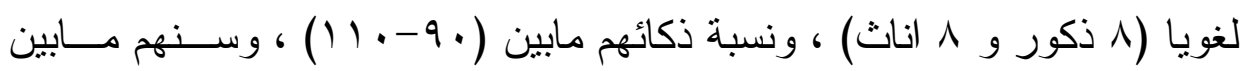

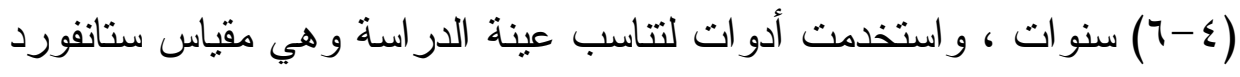

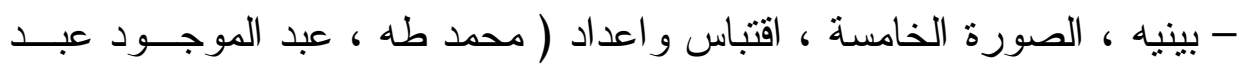

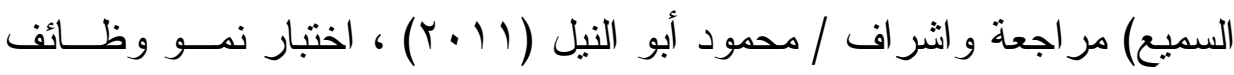

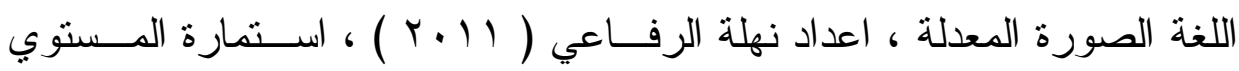




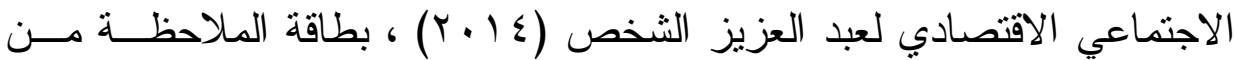

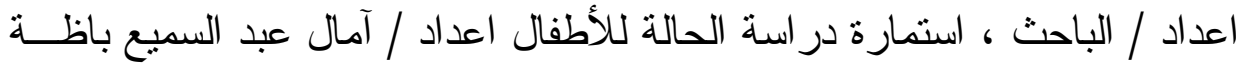

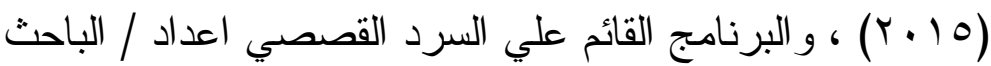

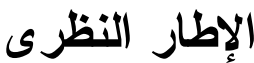

خلق الله سبحانه وتعالى الإنسان فى أحسن تقويم، وفى الوقت نفسه تثناء

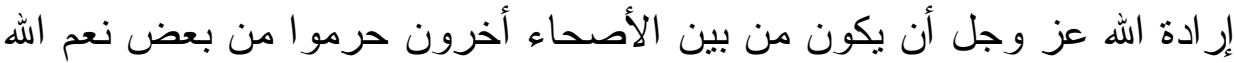
التى تفضل بها على عبادة، فظهرت فئات ذوى الإحتياجات الخاصة، مهما كانت صغيرة أو كبيرة، متعلمة أو غير متعلمة، فالطفل ذوى الإحتباجات الخاصة هو

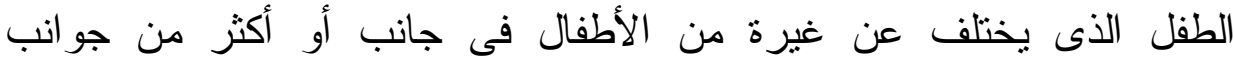
شخصيتة، بحيث يبلغ هذا الإختلاف من الدرجة التى تشعر عندها الجماعة التى التى يعيش معها ذلك الطفل أنه بحاجة إلى خدمات معينة تختلف عن تلك الخدمات النى تقدم للأطفال العاديين، وهذا الإختلاف قد يكون فى أى جانب من جوانب النمو المختلفة (العقلى - الجسمى - النفسى - الإجتماعى) وقد يجمع بين عدد الإنداف من هذه الجو انب فى وقت و احد.

ويهتم علماء النفس إهتماما كبير ا بدر اسة اللغه الناتجة عن العقل البـشرى وبصفه خاصة الكيفية التى تكتسب بها اللغه عند الطفل الصغير، ويرجع الـسبب الهنب

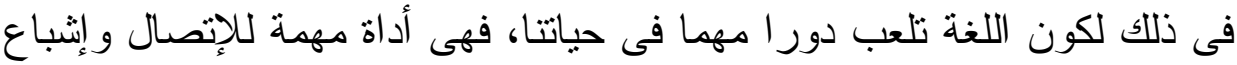

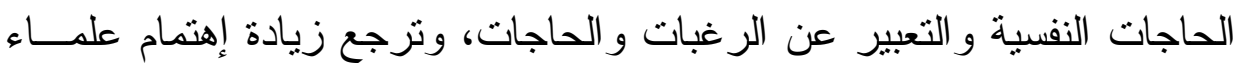

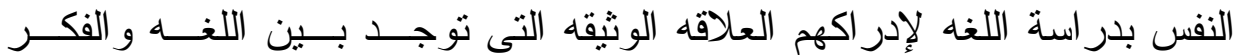

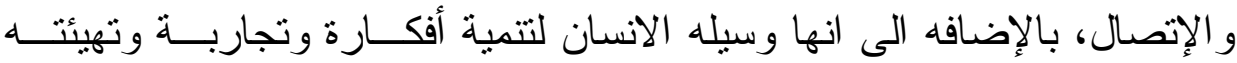
للعطاء و المشاركة فى تحقيق حياة متحضرة، فبو اسطتها يكتسب خبر اته ويندسى 
قدر اته ومهار اته اللازمة لتطوير حياته ويزداد إكتسابه لهذه الخبرات و المهارات

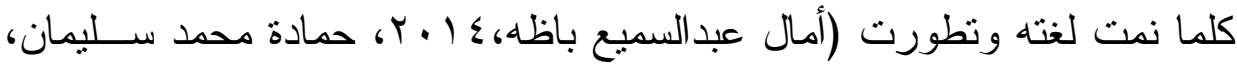

ويرتبط الاضطر اب اللغوى بييئة الطفل النى تعتبر أحد العو امل المــؤثرة

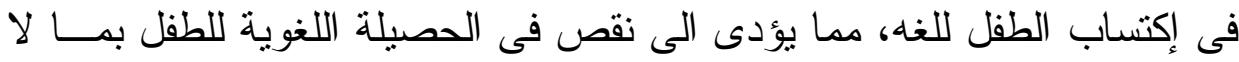

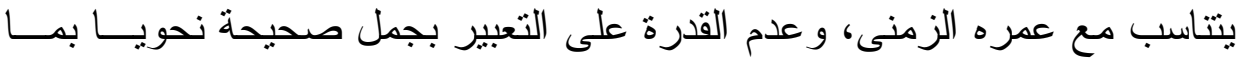
يناسب مر احل نمو اللغه لدى الطفل ( Bridge,2010)

و العلاقه بين الشكلات اللغوية و التو افق النفـسى و الاجتمـــى علاقـــه متبادلة وتفاعلية وليس من السهل الفصل فيها بين السبب و النتيجة، وأن كلا مسن المشكلات اللغوية ومشكلات التو افق قد يكونان نتائج ومؤثرات لعو امــل بيئ.ـــة أخرى تؤدى إلى ظهور كلا منهما (ليلى كرم الدين، ع . . ب)

ويتسم الأطفال الذين يعانون من الإضطر اب اللغوى بالعدو انيـــة البدنيــة

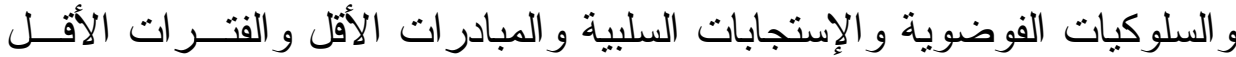

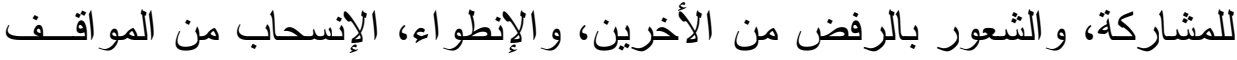

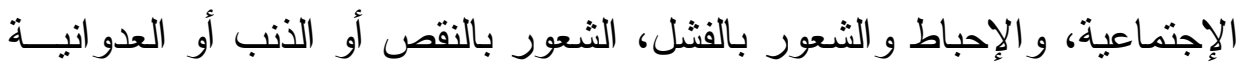

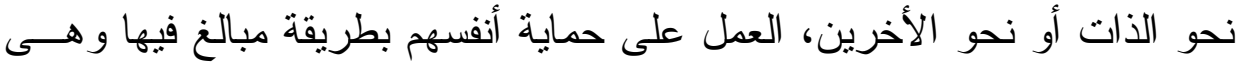

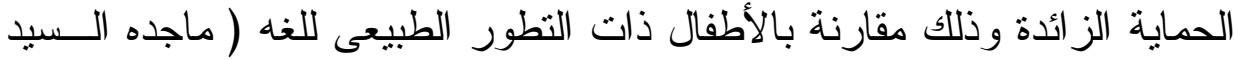

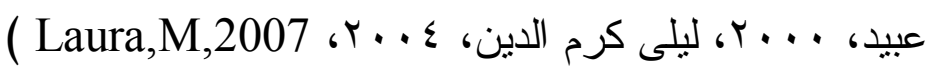
ومما لا شك فيه بأن تحقيق الإهتمام و الرعاية لهؤلاء الأطفال يعود بالنفع

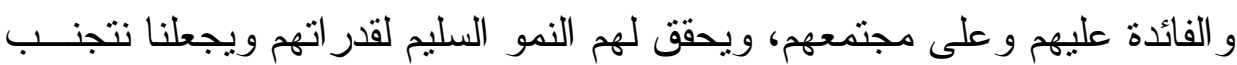


اية مضاعفات قد تترتب على إنظظار الطفل حتى ينقدم فى عمره، إعتمادا علـى

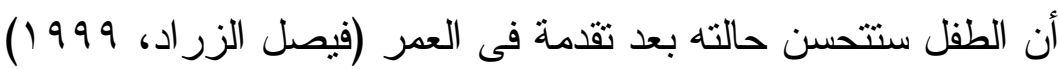
ولذلك فإن تأخر اللغه بالنسبة للأطفال فى مرحلة الطفولة المبكــرة مـن

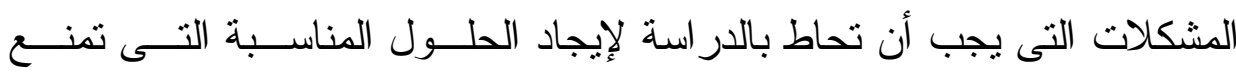

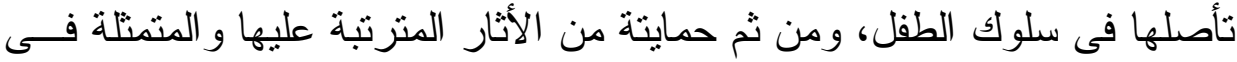

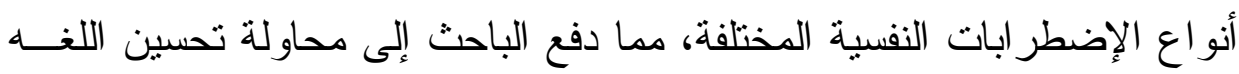

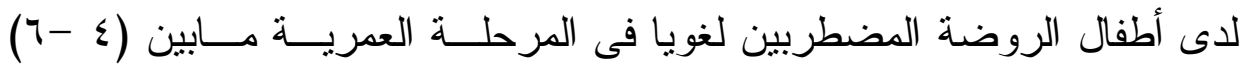

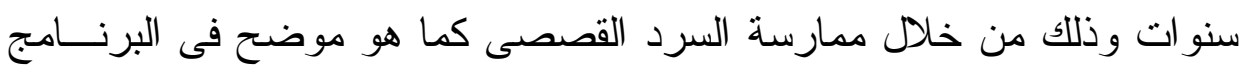
المقدم فى هذه الدر اسة.

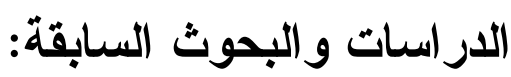

ويصنف الباحث البحوث و الدر اسات السابقة وفقـــا للتســــل الزمنـــي ،

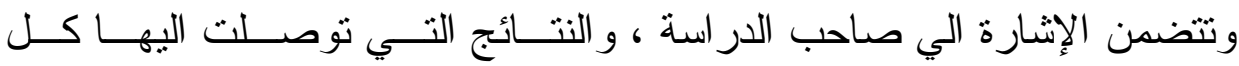
در اسة .

در اسة ريبان (Rubin,EF,2005): هدفت هذه الدر اسة إلــى اســتخدام القصة فى معالجة اضطر ابات النطق لاى الأطفال ذوي الاضطر ابات النطقيــة، النها

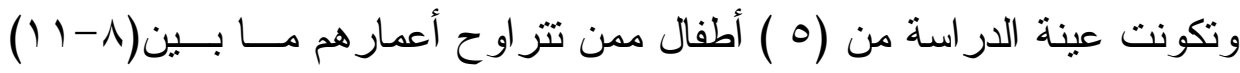
عامًا، حيث تم الاستعانة بأدوات عدة في الدراسة منها اختبار التييز بين النطق

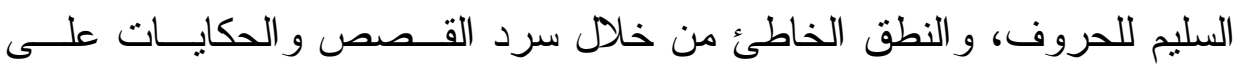

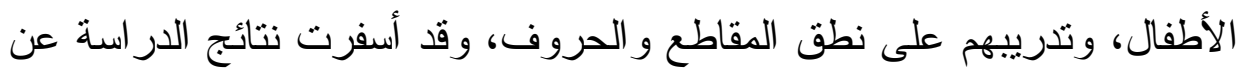

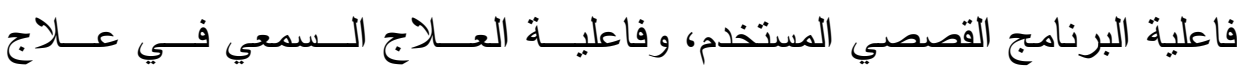
اضطر ابات النطق لدى الأطفال. 


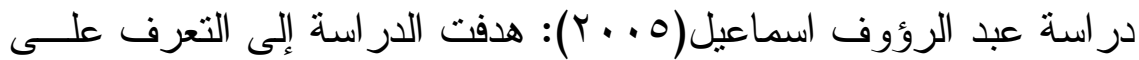

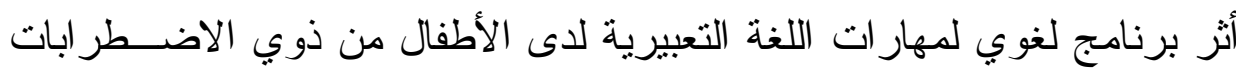

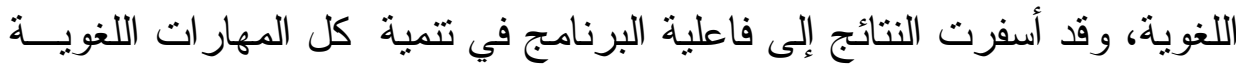

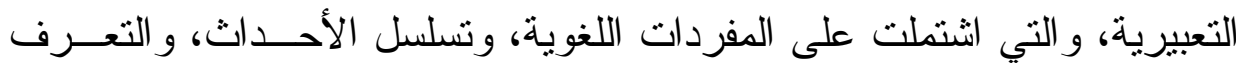

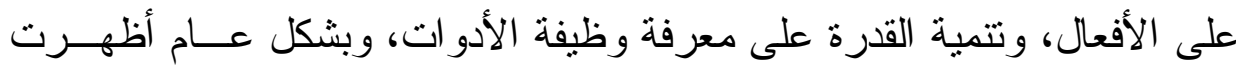

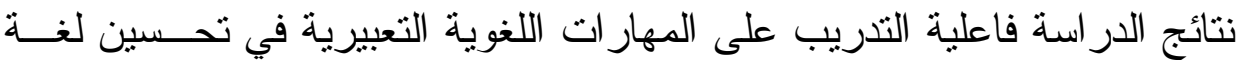
الأطفال ذوي الاضطر ابات اللغوية التعبيرية.

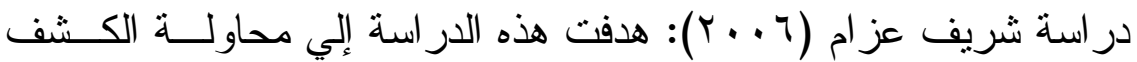

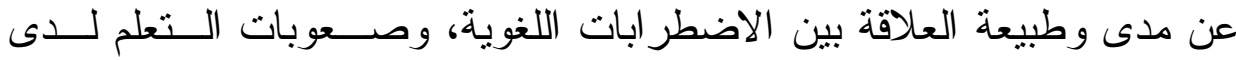

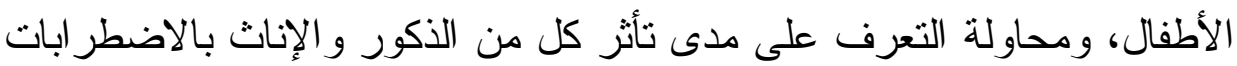

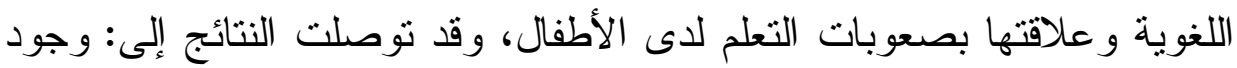

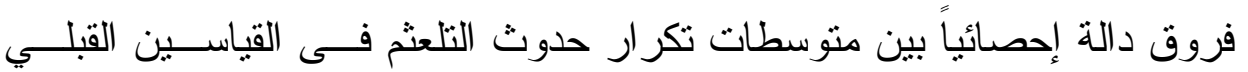

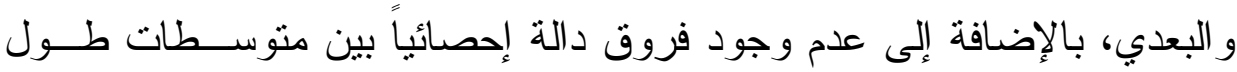
فترة التلعثم في القباسين القبلي و البعدي. وكذلك وجود فروق دالة إحصائيًا بــين

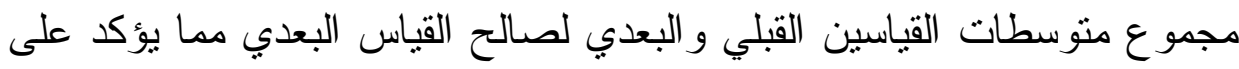

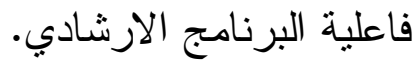

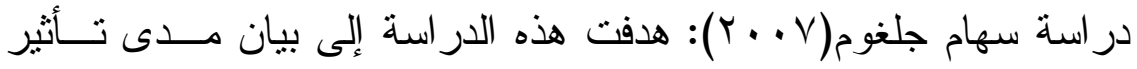

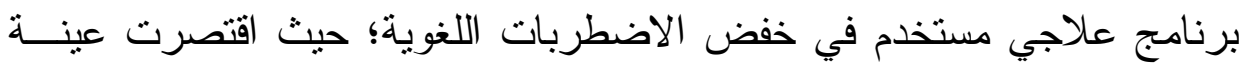
الدر اسة على طالب واحد(در اسة حالة)، وهو طالب في الصف الثاني الابتدائي،

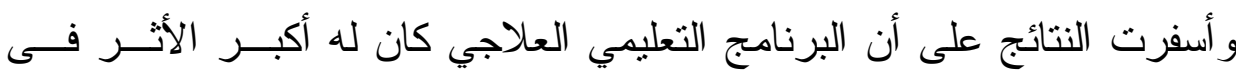

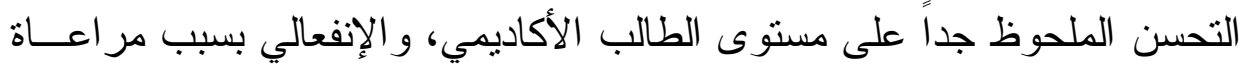
البرنامج المتكامل للمهار ات الأساسية اللغوية عند الطفل. 


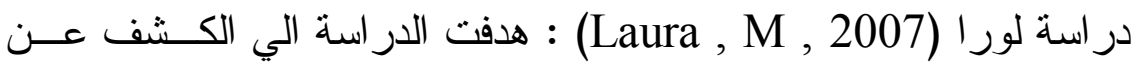

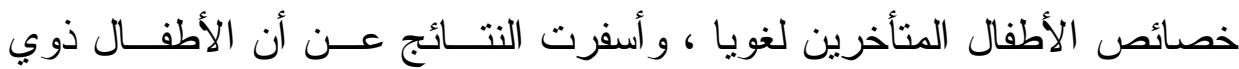

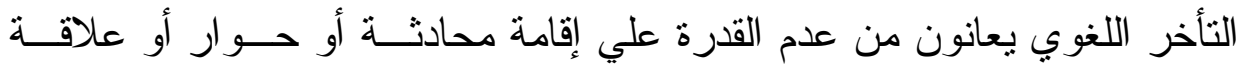
اجتماعية وضعف في القدرة علي الإنتباه و الذاكرة السمعية و الوعي ويميلون الي الي الي

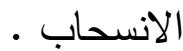

در اسة ويس (Weiss , M , 2007) : هـــفت الدر اســـة الــي تتميــة

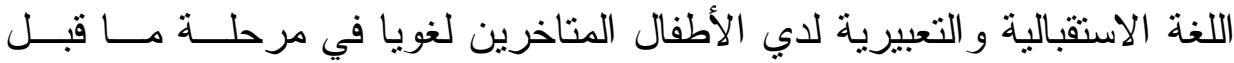

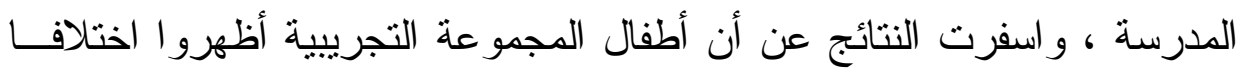

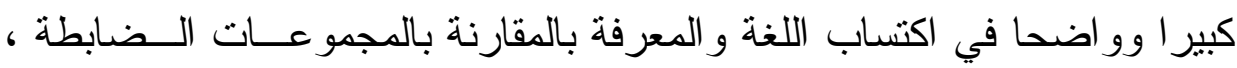

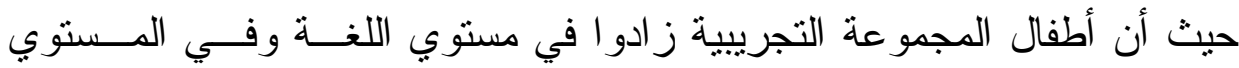

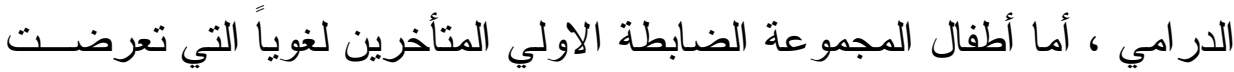

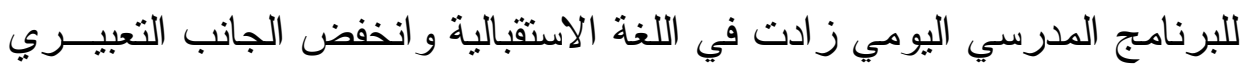

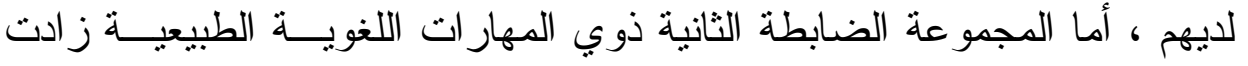
لليهم اللغة الاستقبالية وكل المهارات اللغوية ، ولكن إنخفض الجانب التعبيــري

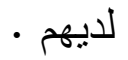

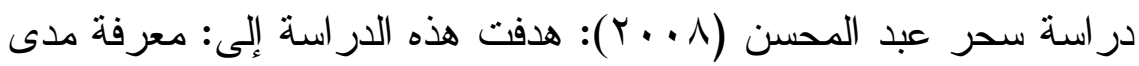

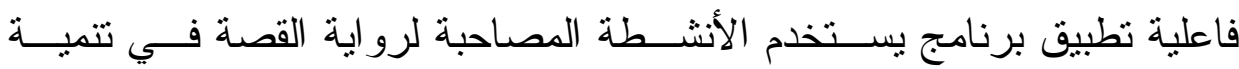

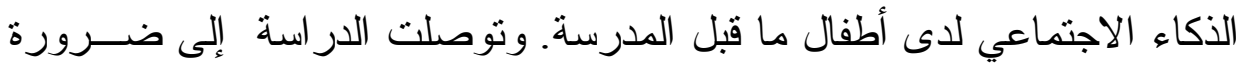

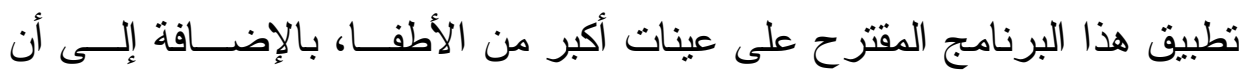

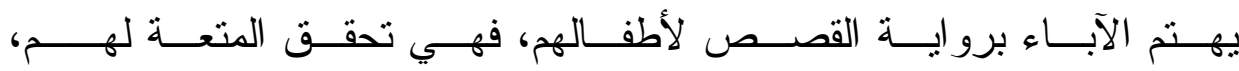

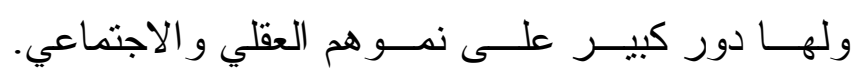




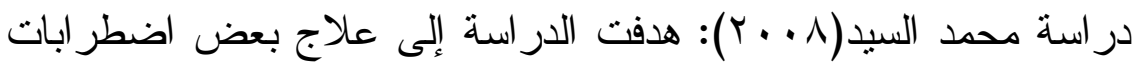

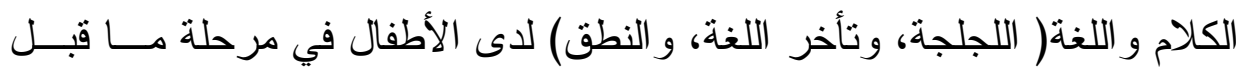

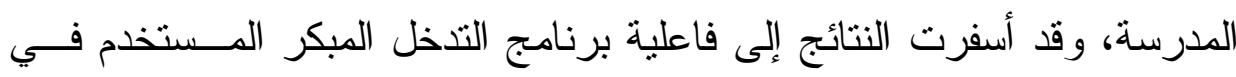
الدر اسة في علاج بعض اضطربات الكلام و اللغة لدى هؤ لاء الأطفال.

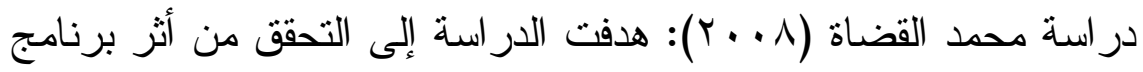
تدريبي قائم على استر اتيجيتي لعب الدور، و القصة في تتمية الاستعداد للقــر اءة

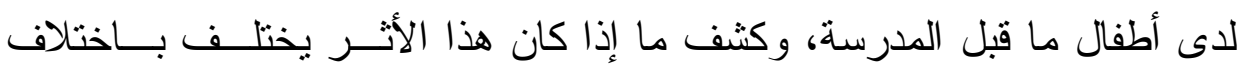

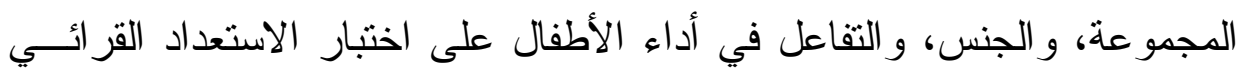

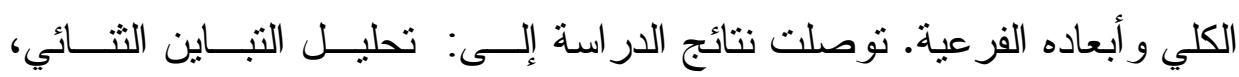

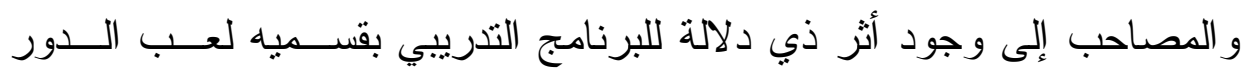

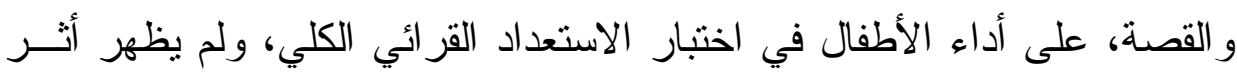

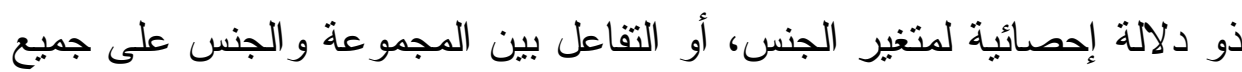

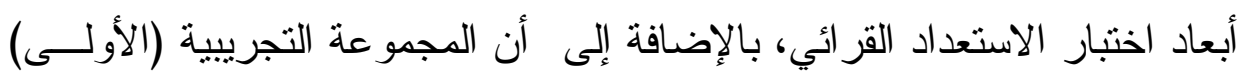

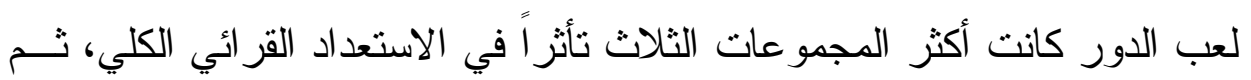

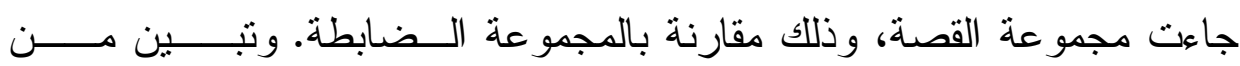

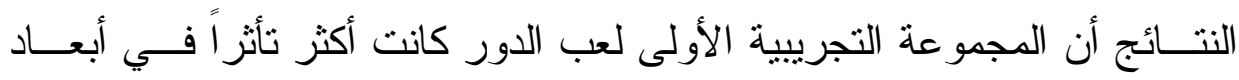

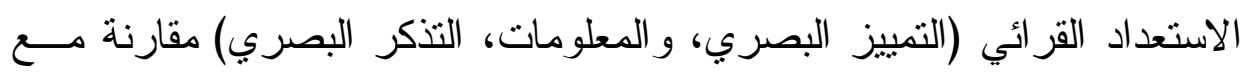

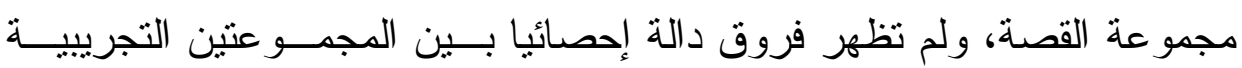
و الضابطة على بقية الأبعاد

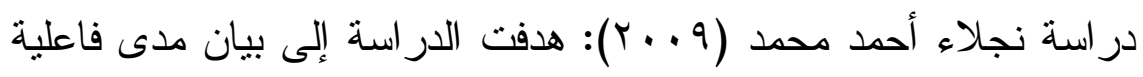

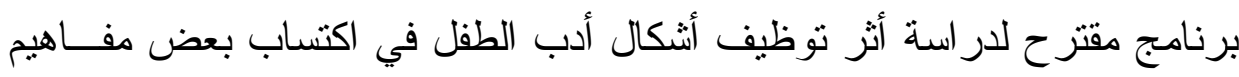

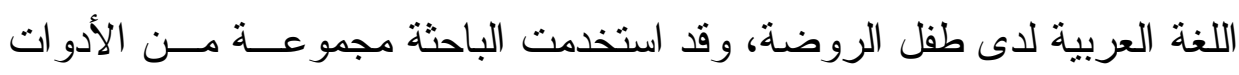


منها اختبار التز اكيب النحوية، واختبار مهار ات التذوق الأدبي، واختبــار ذكــاء

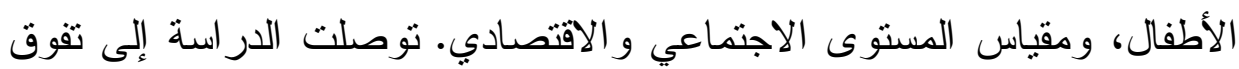

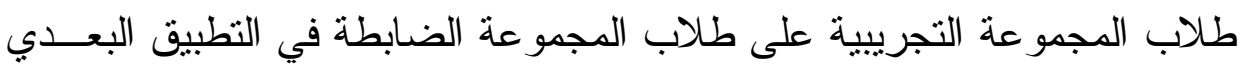

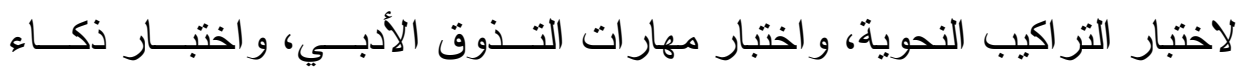

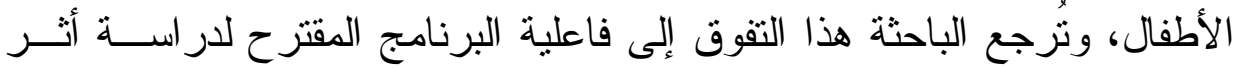

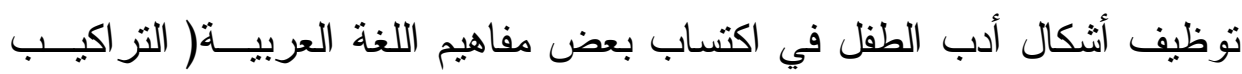
النحوية، و التذوق الأدبي) لدى طفل الروضة.

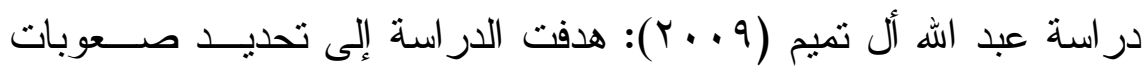

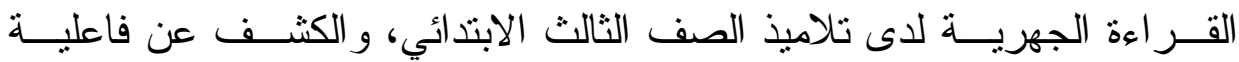
القصص المسجلة على الأقر اص المدمجة في علاج صعوبات القر اءة لدى تلاميذ الصف الثالث الابتدائي على مستوى تعرف المقروء و النطــق بها، توصلت نتائج

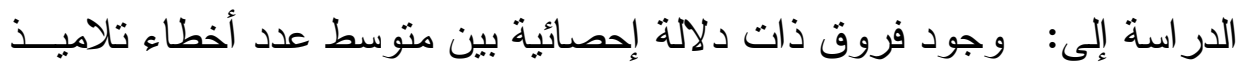
المجموعة التجريبية، و المجموعة الــضابطة فـي صـــوبة الإضـــافة لــصالح المجموعة التجريبية في الاختبار البعدي، بالإضـافه الى وجود فروق ذات دلالـــة

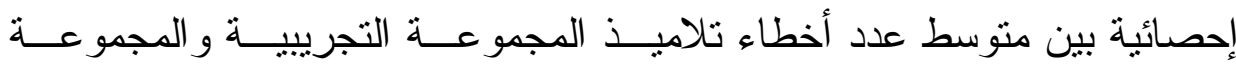
الضابطة فى صعوبة القر اعة المتقطعة لصالح المجموعة التجريبية فى الاختبـار

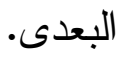

در اسة نايل عبد الله و عبد الر ازق يوسف (9 . . ץ): معالجة خمس قصص

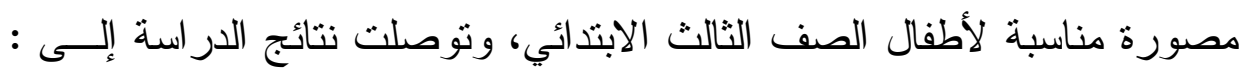

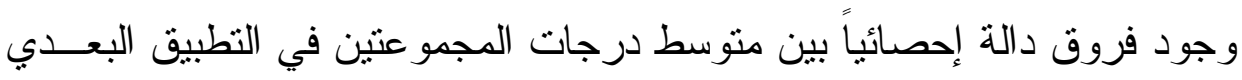

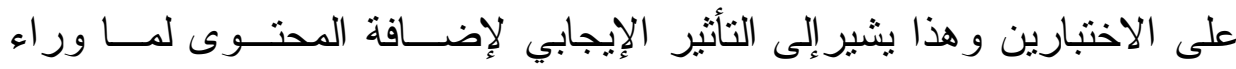

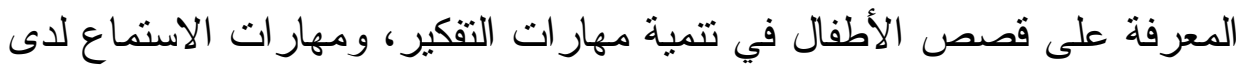


أطفال الصف الثالث ـ من خلال معالجة خمس قصص باســتخدام اســتر اتيجيات

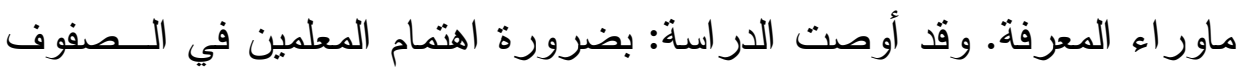

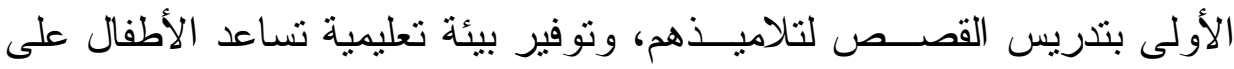

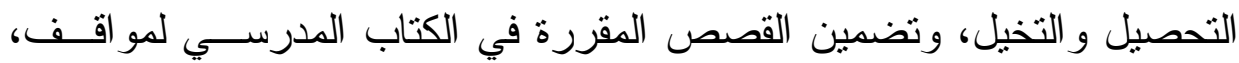
و ألفاظ، وجمل تدل على التفكير لما ور اء معرفي.

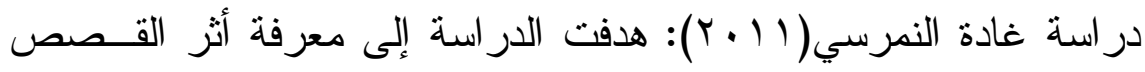

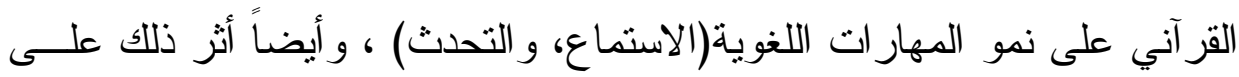

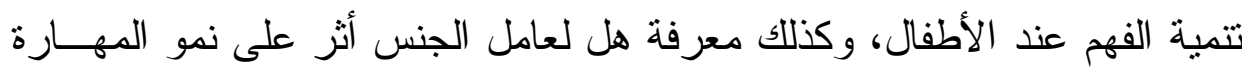
اللغوية بعد تطبيق البرنامج، وقد توصلت الدراسة إلى فاعلية البرنــامج القـائم على القصص القر آني في تتمية الفهم عند الأطفال و المهار ات اللغوية لديهم.

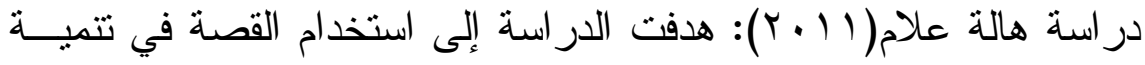

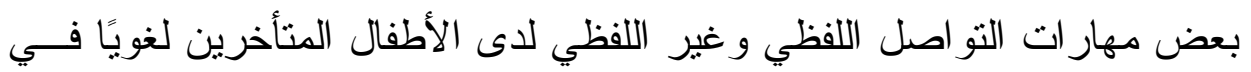

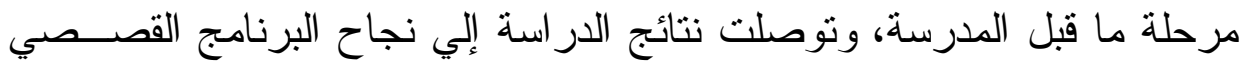
في تتمية بعض مهار ات التو اصل اللفظي وغير اللفظي لدى الأطفال المتــأخرين لغويًا في مرحلة ما قبل المدرسة.

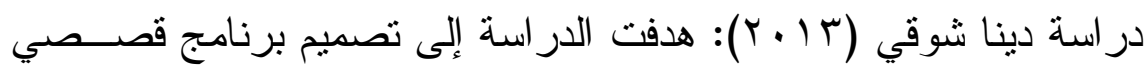

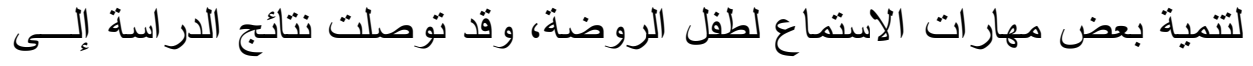
أن البرنامج القصصي له أثنر إيجابي في تتمية بعض مهار ات الاستماع للاطفــال

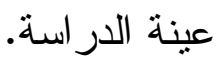
در اسة سلوي عز الدين محمد (ع ا ب Y) : هدفت الدراسة الي التعرف علي

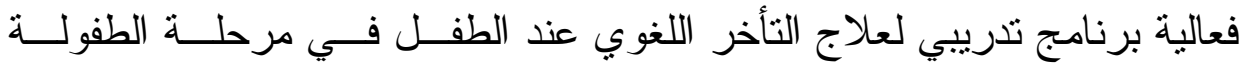


المبكرة ، وتوصلت الدر اسة الي وجود فروق ذات دلالة إحصائية بــين أطفــال المجمو عة التجرييية و المجموعة الضابطة لصالح المجموعة التجرييية مما يشير

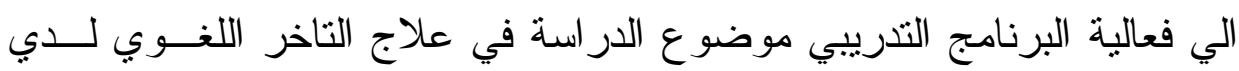
الأطفال في مرحلة الطفولة المبكرة .

\section{التعقيب على الار اسات و البحوث السابقة:}

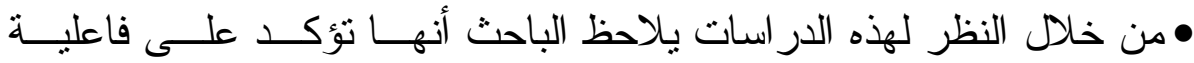

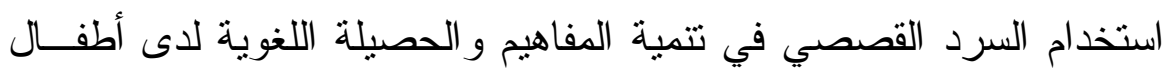

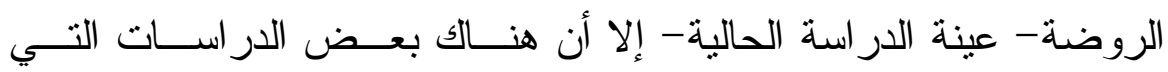

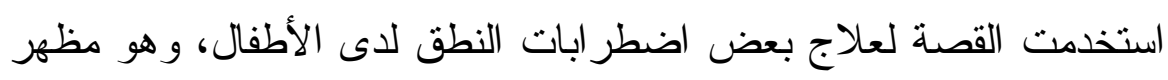
من مظاهر الاضطر ابات اللغوية.

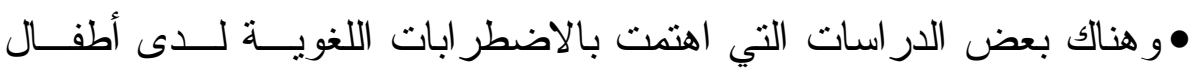

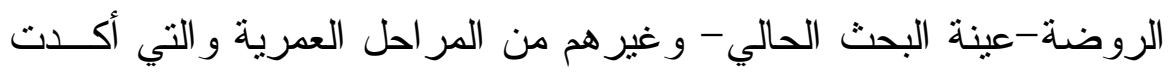

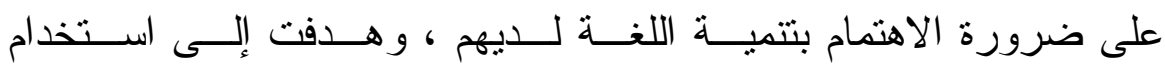

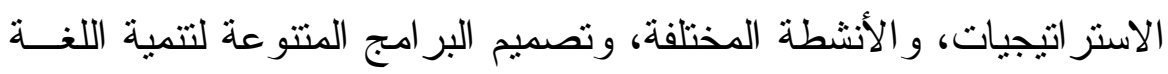
لديهم وعلاج الاضطر ابات للديهم. مما دفع الباحث إلى الاهتمام بهذه الفئـــة

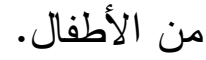
•ونجد أن الدراسة الحالية اختلفت عن الدراسات السابقة فى تصميم برنــامج

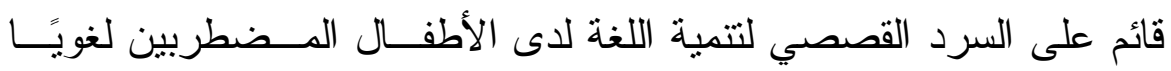

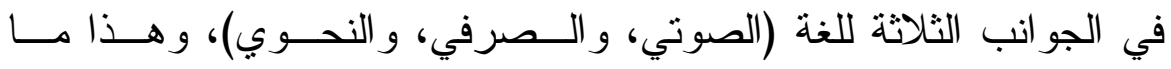

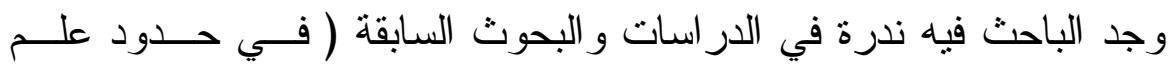


أوجه الاستفادة من الاراسات و البحوث السابقة:

يمكن تحديد أوجه الاستفادة من نتائج الدراسات السابقة في النقاط التالية:

• الاستفادة من الأطر النظرية في معرفة أكثر عن خـصائص اللغــة لــدى

الأطفال في هذه المرحلة.

•معرفة أثز إستر اتيجية السرد القصصي علي عينــة الدر اســـة للاســتفادة

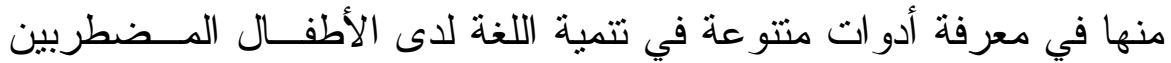
لغويًا.

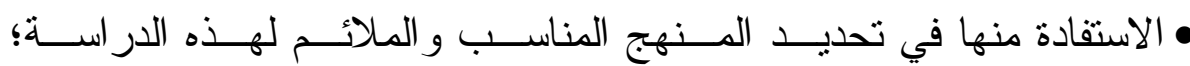

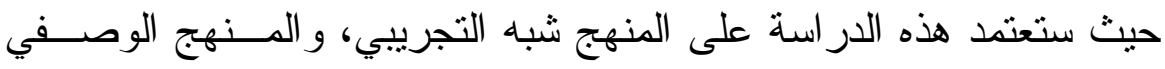
التحليلي.

• الاستفادة من نتائجها في تفسير النتائج الإحصائية، التي يستخلصها الباحـث

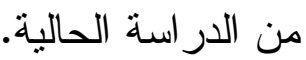

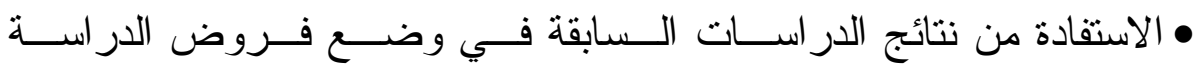

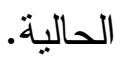

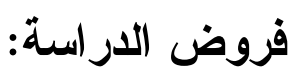

ا. توجد فروق ذات دلالة إحصائية في منوسط درجات الاضطر اب اللغوي حسب القياسات المتعددة(قبلي، تكويني، بعدي) في اختبار نـــو وظــائف اللغة لاى الأطفال المضطربين لغويًا. r. توجد فروق ذات دلالة إحصائية في متوسط درجات الاضطر اب اللغــوي

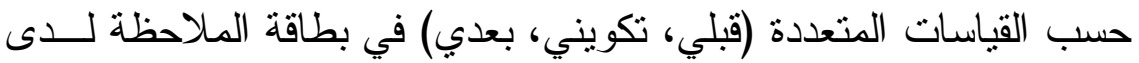
الأطفال المضطربين لغوياً. 
r. يوجد تأثير لمتغير الجنس على الفروق في القياســات المتعـددة (قبلــي، تكويني، بعدي) لدى الأطفال المضطربين لغويًا فى اختبار نمو وظــائف اللغة. ـ. توجد مجموعة من العو امل الدينامية المسئولة عـن الاســتفادة أو عــدم

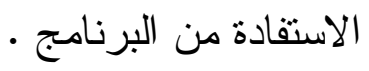

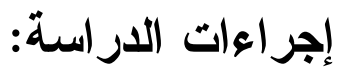

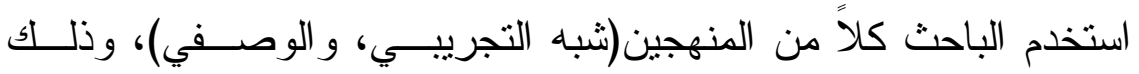
لتحقيق أهداف الدر اسة.

ا ـ التصميم شبه التجريبي: و اعتمد الباحث في هذه الدر اســـة علــى نظــام المجمو عة الو احدة، لمعرفة مدى فاعلية برنامج قـائم علــى إســـز اتيجية السرد القصصي في نتمية اللغة لدى الأطفال المضطربين لغوياً. r. المنهج الوصفي التحليلي :قـام الباحث بالاســتعانة بهــذا المــنهج فـي ضوء الأدبيات التربــوية، ومر اجعــة البحــوث و الدر اســات الــسابقة ، وجمع المعلومات و البيانات حول طريقة السرد القصــصي، ثـــ إعــداد البرنامج، ودليــلـ المعلـــم بطريقــة السرد القصصي؛ ليتم تعليم أطفــال

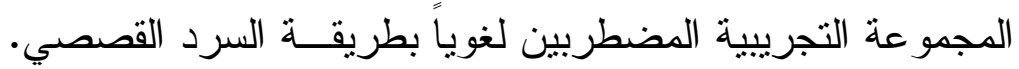
عينة الدراسة: شملت عينة الدر اسـة على (7 ا ) طفل ممن يعانون من اضــطر اب اللغـــة

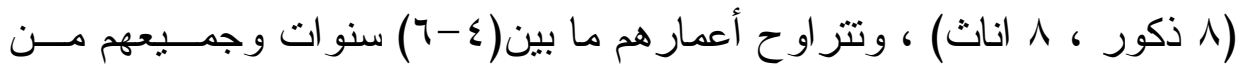
روضة هابي كيدز - المنصورة - دقهلية ، وتم تشخيصهم من قبل أخـصـئيات التخاطب في مركز التخاطب بكلية التربية جامعة المنصورة، و التـي اختيـرت 
بالطريقة القصدية، وقام الباحث بالتأكد من التكافؤ بين الأطفال من حيث العهـر

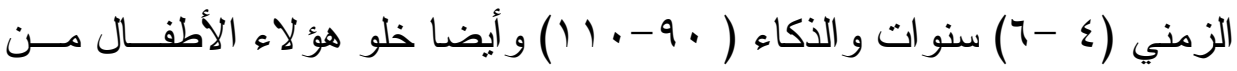

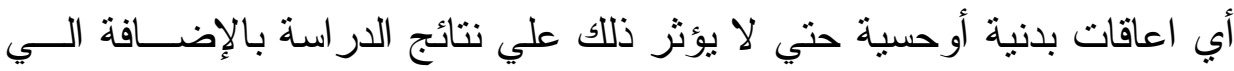

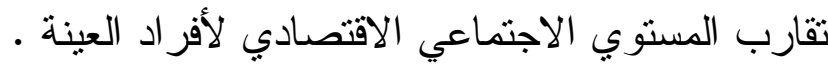
أدوات الدراسة :

أو لا : مقياس ستانفورد - بينيه ، الصورة الخامسسة ، اقتبـساس واعـداد

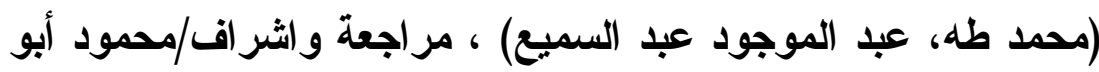

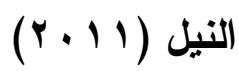

ويعد مقياس ستانفورد - بينيه بصوره المتعددة من أهــــ أدوات القيـــاس

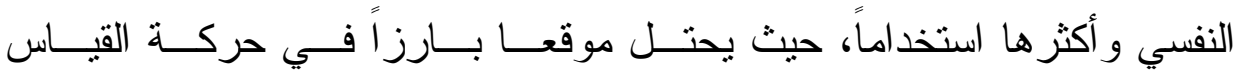

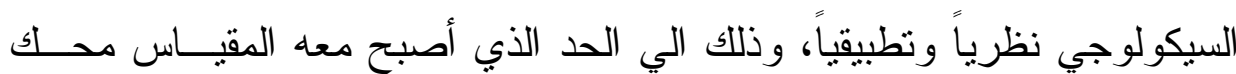

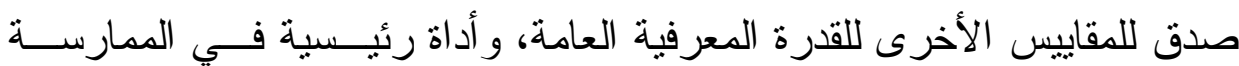

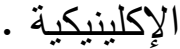

وقد بدأ الاعداد للصورة الخامسة من مقيــاس ســانفورد - بينيــهـ عـام

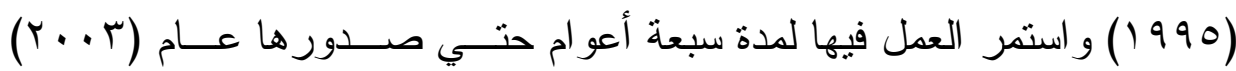
وذللك علي يد فريق عمل يقوده البروفيسور (جال رويد) Gale Roid رئسيس وليس قسم القياس النفسي و التربوي و استاذ التربية الخاصة بجامعة فاندربيلت بمدينــة ناثنفيل بو لاية تتسي الأمريكية .

وتمتاز الصورة الخامسة لمقياس ستانفورد - بينيه بإتساع نطــاق القيــاس بحيث إحتوي علي العديد من الفقرات المخصصة لقياس أعلي مستويات القـدرة العقلية من ناحية ، ولقياس المستويات العقلية الدنيا من ناحية أخري ، وبعبـارة 
أخري، فان الصورة الخامسة تمتاز بزيادة مستوي كـلـ مــن سـقف القيــاس

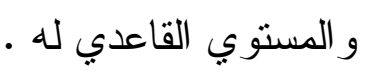

ومن مميزات مقياس ستانفورد - بينيه ، الصورة الخامسة :

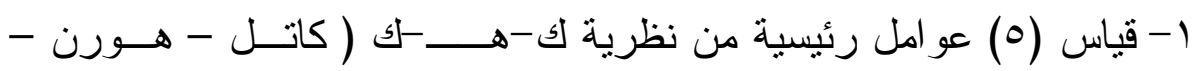

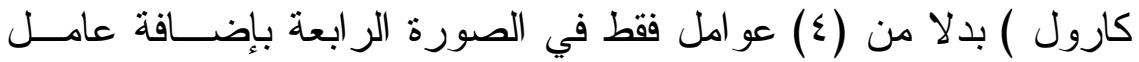

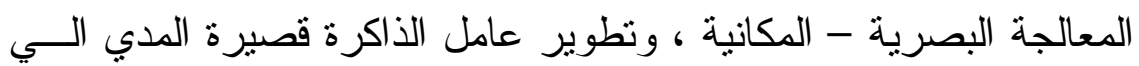

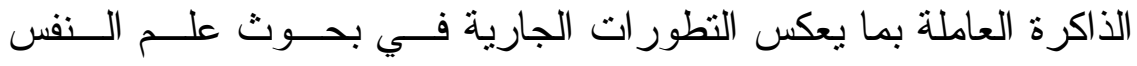

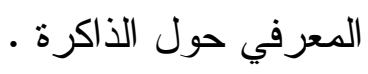

r- إعداد الدقياس بحيث يكون متوسط الذكاء (.. (1) و الانحر اف المعيــاري

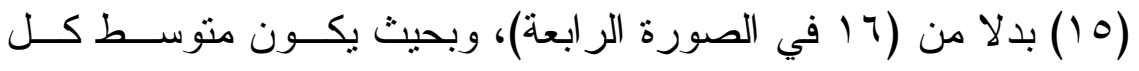

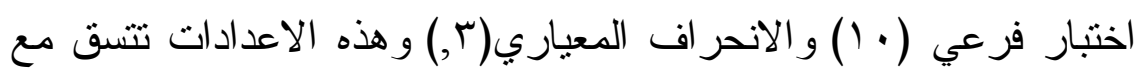

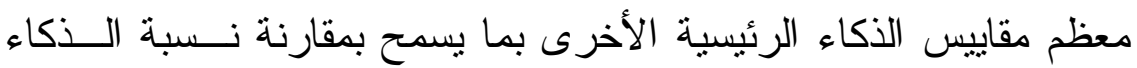

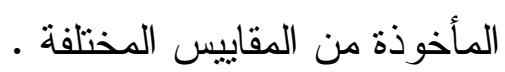

r-وجود أكبر للعوامل غير اللفظية، وتتمنل في وجود عدد متسـساوي مــن

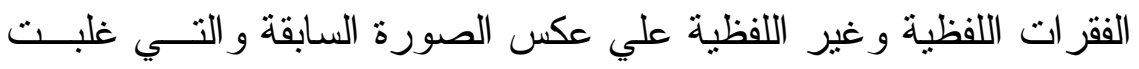

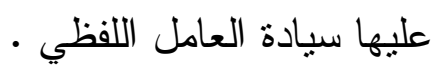
ع- توسيع نطاق الذكاء المقاس بإستخدام نسب الذكاء الممتدة EXIQ و التــي

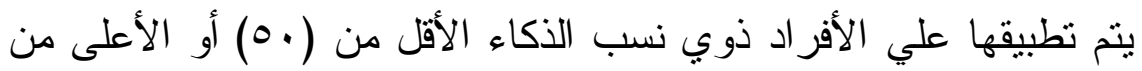

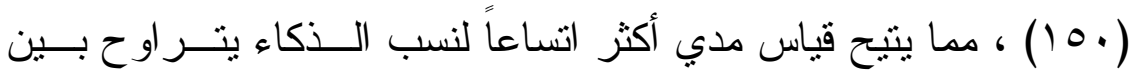

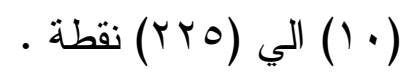
0- استخدام مو اد أكثر جاذبية للأطفال في مرحلة ماقبل المدرسة مما يـسكل

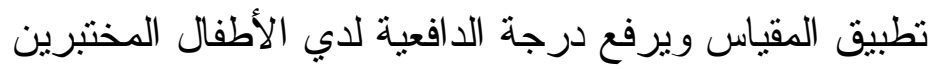




\section{وصف المقياس :}

يطبق مقياس ستانفورد - بينيه : الصورة الخامسة بشكل فــردي لتقيـــيم

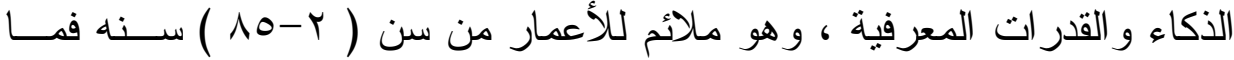

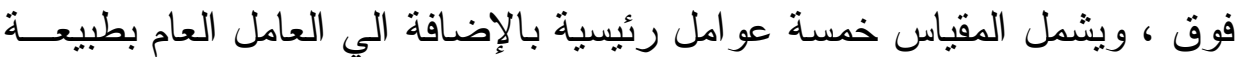

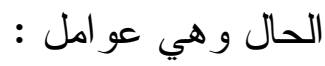

1 : Fluid Reasoning : الإستدلال السائل

يشير الاستدلال السائل الي قــدرة الــشخص علــي اكتـشـاف العلاقــات و الربط بين المعلومات ـ ويتضمن الاستخلال السائل استخدام كل من الاســتلال

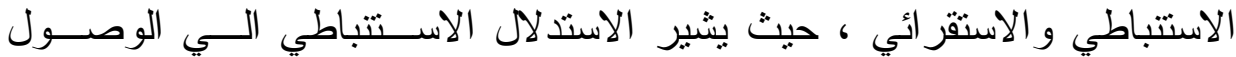

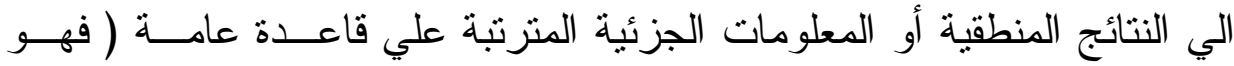

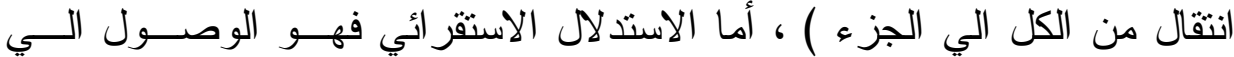

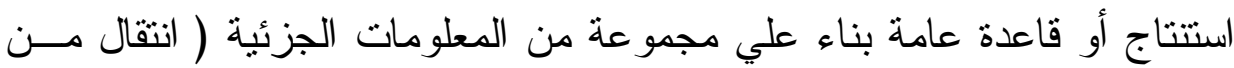

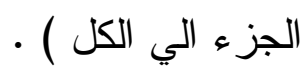

: Knowledge : المعرفة

المعرفة هنا تثبر الي كمية المعلومات العامة لدي الثخص ، و المختزنــة

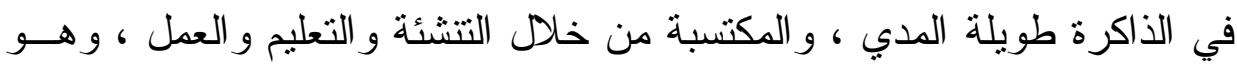

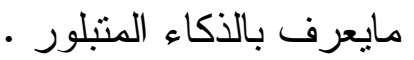

\section{: Reasoning Quantitive : الإستتلال الكمي}

يثير الاستدلال الكمي الي قدرة الثخص ومهارته في اســتخدام الأرقــام

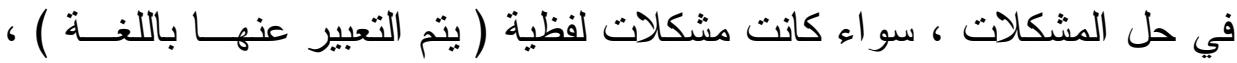


أو مشكلات مصورة ( يتم التعبير عنها بالصور ) ـ و الاستدلال الكمي هنا يركز

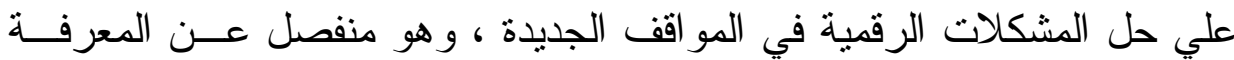

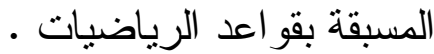

ع - الذاكرة العاملة : Working Memory

تتشير الذاكرة العاملة الي القدرة علي التعامل مع المعلومات المخزونة في

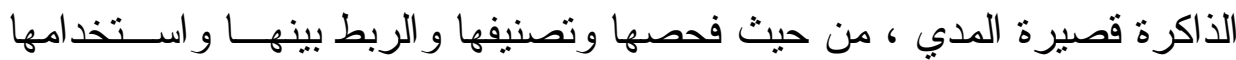
حسب منطلبات المو اقف المختلفة .

ه - Visual - Spatial Processing : المعالجة البصرية - المكانية

تشير المعالجة البصرية - المكانية الــي القــدرة علــي ادر الك الأنمــاط

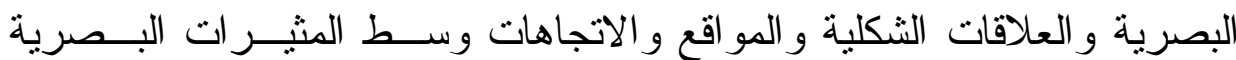

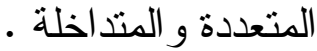

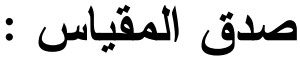

بلغ العدد الإجمالي لعينة التقنين الرئيسية (•VVV) فرداً مــوزعين علـي

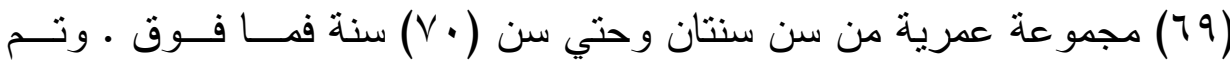
تقسيم عينة البحث لثلاث مناطق رئيسية ، (1) المنطقة المركزية وشملت القاهرة الكبرى و المحافظات المجاورة لها ( القاهرة ، الجيزة ، القليوبيــة ، المنوفيـــة ،

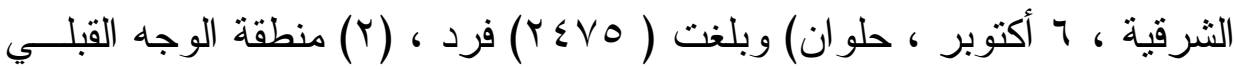

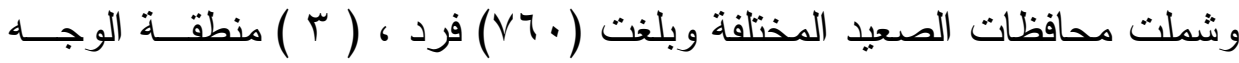
البحري وشملت مدن القناة و الإسكندرية و الدقهلية و الغربية و البحيرة وكفر الثنيخ

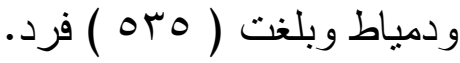




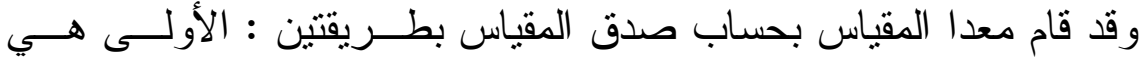

صدق التمبيز العمري حيث تم قياس قدرة الاختبار ات الفرعية المختلفــة علــي

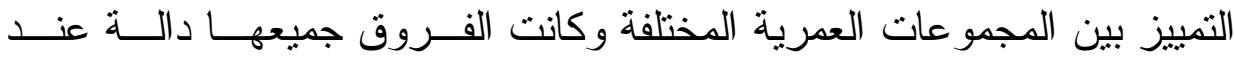
مستوي ( ( +, · ) ، و الثانية هي حساب معامل ارنباط نـسب ذكــاء المقيــاس

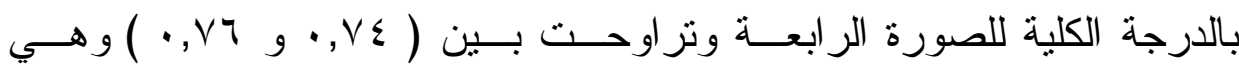
معاملات صدق مقبولة بوجه عام، وتشير الي إرتفاع مستوي صدق المقياس • ثبات المقياس :

قام معدا المقياس بحساب الثبات للاختبار ات الفر عية المختلفــة بطريقتــي إعادة التطبيق و التجزئة النصفية ، وتتشير النتائج الي معاملات الثبات بإســتخدام

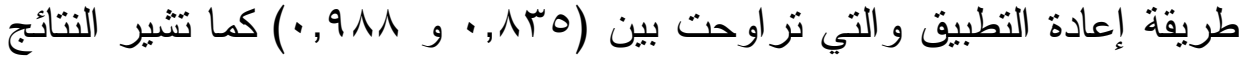

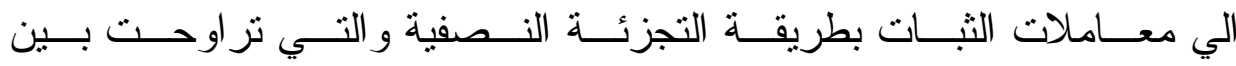

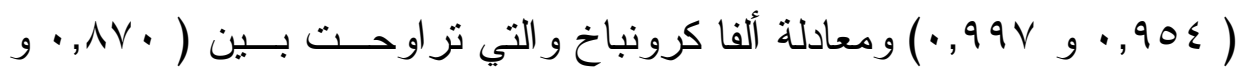
(99, · ·) ، وتثنير النتائج الي أن المقياس يتسم بثبات مرتقع سو اء عـن طريـق إعادة الاختبار أو التجزئة النصفية أو باستخدام معادلة كيودر - ريتشارد سون ، فقد نز اوحت معاملات الثبات علي كل اختبار ات المقياس ونسب الذكاء و العو امل من ( rی, • الي 9^, · ) وبالتالي يتمتع المقياس بدرجة مقبولة من الثبات ، مما يثير الي إمكانية استخدامه في الدر اسة الحالية و الوثوق بالنتائج التـي سيـسـفر

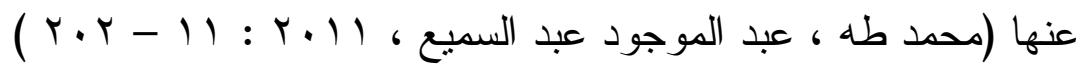
ثبات مقياس ستانفورد - بينيه فى الار اسة الحالية:-

قام الباحث بحساب ثبات مقياس ستانفورد - بينيه فى الدر اســـة الحاليــة بطريقة ألفا كرونباخ، وذلك لحساب معامل ثبات البطاقة فى حالة حذف العبارة،

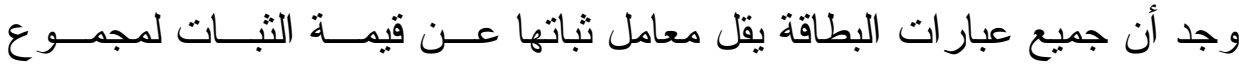


عبار ات الإختبار ككل، إذ تتز اوح قيم معاملات الثبات بطريقة ألفا كرونباخ مــا

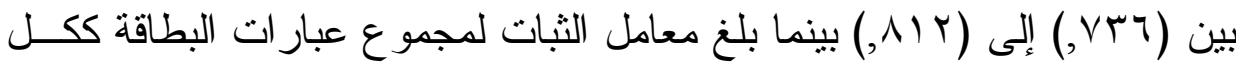

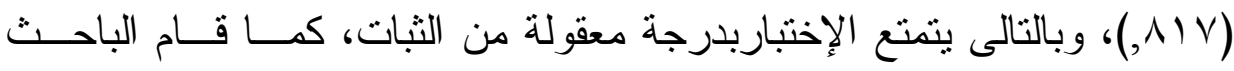

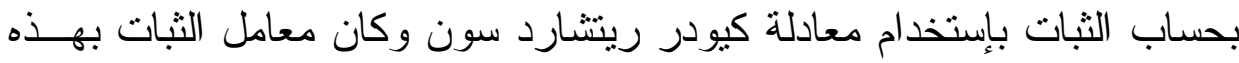

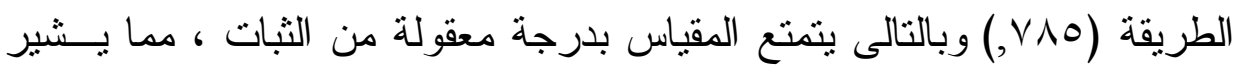

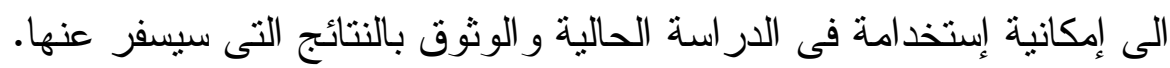
ثانيا : اختبار نمو وظائف اللغة الصورة المعدلة ـ اعداد ـ نهـــة الرفــاعي

$$
:(r \cdot 11)
$$

يعد هذا الاختبار الأول الفريد من نوعه في العالم العربي حيث يقــدم أول

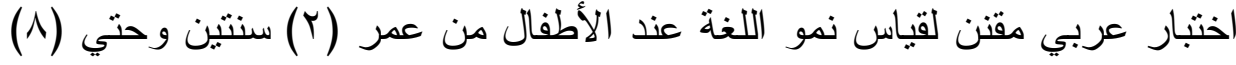

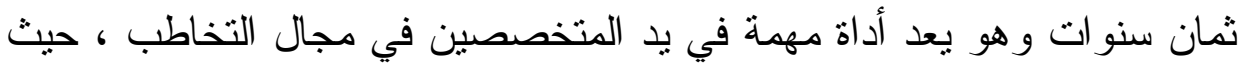

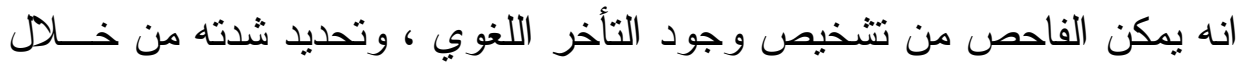

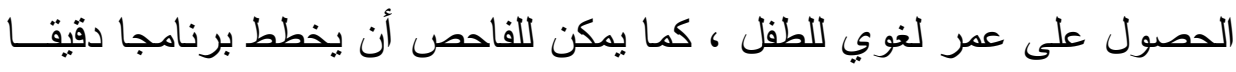
للطفل المتأخر لغوياً بعد تطبيق هذا الاختبار ، ثم متابعة الحالة بعد ذلك بإعــادة

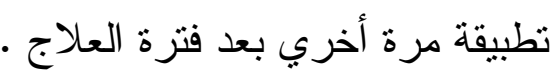
الهذف من الاختبار : يهاف الاختبار الي مايلي :

1- تحديد المشكلة اللغوية ، أسبابها ، وطبيعتها ، وحجمها .

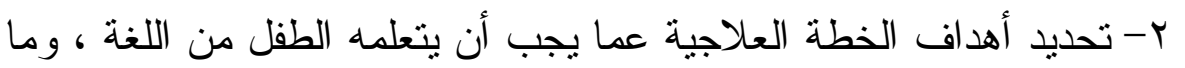

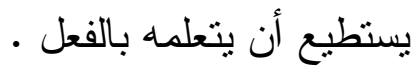

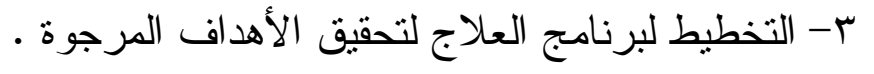

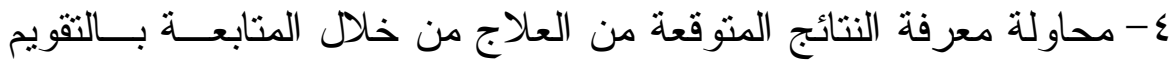

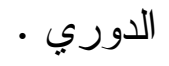


وصف الاختبار :

تتكون صفحات الاختبار المعدل من ستة أجزاء ، كل جزء يمثـل عهـر

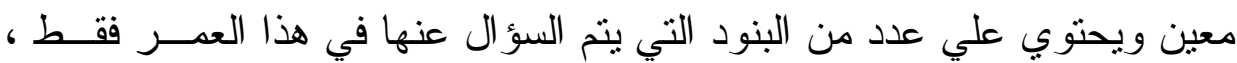
وقد تم ترتيب البنود على حسب الصعوبة من السهل الي الصعب ، وقد تم فصل الصفحات التي بها طريقة إلقاء البنود لكل الأعمار في مجموعــات ، وحــددها

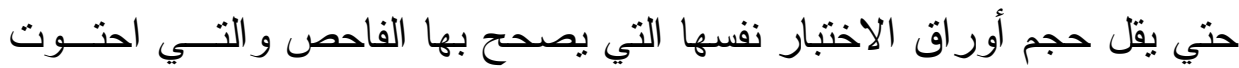

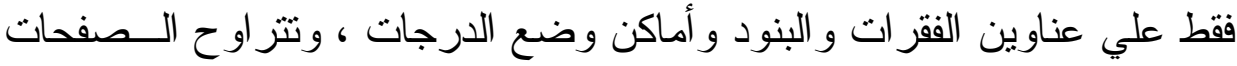

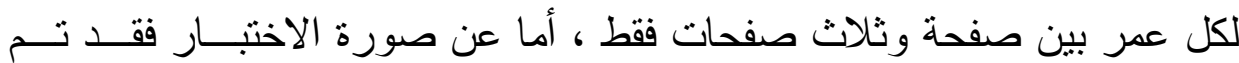
ترتيبها في سته مجمو عات مختلفة بحسب العمر ، بالإضافة الي مجموعة ســابعة تحتوي علي المجموعات المضمونية كلها . ويقيس الاختبار الجواتب اللغوية التالية :

1- إختبار اللغة الإستقبالية Receptive Language ( أي فهم السياق ) . r- إختبار اللغة التعبيريــة Expressive Language ( أبي التعبيــر عـن الإنس

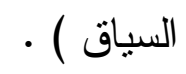

r- إختبار مضمون اللغة Semantics ( أي النواحي الدلالية للغة ) .

ع - إختبار البر اجماتيقا Pragmatics ( أب الاستخدام اللغوي ) .

0- إختبار المستوي القطعي : ويشمل اختبـار النطـق واختبـار الاطـــار اللحني. ومن خلال هذه الجو انب اللغوية للاختبار يمكن إستخر اج معدلات العهـر اللغوي الاستقبالي و التعبيري و المشترك ( المختلط ) ويكون كما يلي : معدل العمر الاستقبالي= العمر الاستقبالي/العمر الزمنى × ... 
معدل العمر التعبيري = العمر التعبيري/العمر الزمني××...

معدل العدر اللغوي المشترك = العمر اللغوي المشترك/العدر الزمني×× . . العدر اللغوي المشنزك = العدر الاستقبالي + العدر التعبيري / العدر الزمني

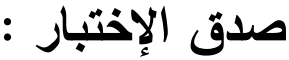

قامت معدة الاختبار بحساب صدق إختبار نمو وظائف اللغـــة الـصصورة

المعدلة بتطبيق معامل بيرسون بتحقيق معاملات ارتباطات عالية الدلالــــة بـين استجابات الأطفال في الاعمار المختلفة لعينــة الاختبــار المعـدل و اســتجابات الأطفال في العينة الاصلية للتقنين ، و النتائج يوضحها جدول( (1).

\section{جدول (1)}

معاملات صدق اختبار نمو وظائف اللغة الصورة المعدلة

\begin{tabular}{|c|c|c|}
\hline \multicolumn{3}{|c|}{ باستخدام معامل بيرسون } \\
\hline مستوي الدلالة & معامل بيرسون & العمر بالسنوات \\
\hline$\cdot, \cdot 1$ & $\cdot, 917$ & $r-r$ \\
\hline$\cdot, \cdot 1$ & $\cdot, \vee \vee 9$ & $\varepsilon-r$ \\
\hline$\cdot, \cdot 1$ & $\cdot, 9 r V$ & $0-\varepsilon$ \\
\hline$\cdot, \cdot 1$ & $\cdot, 9 \cdot 7$ & $7-0$ \\
\hline$\cdot, \cdot 1$ & $\cdot,(\vee)$ & $V-7$ \\
\hline$\cdot, \cdot 1$ & $\cdot, \times)$. & $\wedge-\vee$ \\
\hline
\end{tabular}

يتضح من الجدول السابق أن اختبــار نمــو وظــائف اللغـــة الــصورة

المعدلة صادق لقياس اللغة الاستقبالية و التعبيرية ( نهلة الرفاعي ، 11 (1 ، ، 1- 


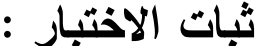

قامت معدة الاختبار بتطبيق الاختبار المعدل علي عينـــة مــن الأطفــال

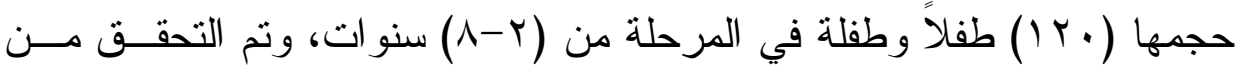

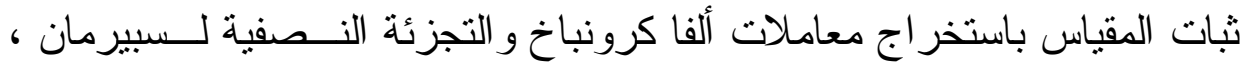

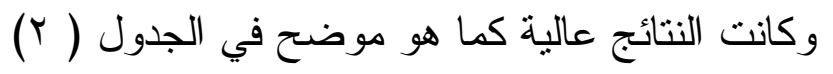

جدول (r)

معاملات ثبات اختبار نمو وظائف اللغة الصورة المعللة بطريقتي ألفا كرونباخ والتجزئة النصفية

\begin{tabular}{|c|c|c|}
\hline التجزئة النصفية & معامل ألفا كرونباخ & العمر بالسنوات \\
\hline$\cdot, \Lambda \vee \leqslant$ & $\cdot, \wedge \leqslant \vee$ & $r-r$ \\
\hline$\cdot, T \vee V$ & $\cdot, \vee \vee \vee$ & $\varepsilon-\mu$ \\
\hline •, $\vee 99$ & $\cdot, \wedge 71$ & $0-\varepsilon$ \\
\hline$\cdot, 7.9$ & $\cdot, \vee \backslash \wedge$ & $7-0$ \\
\hline$\cdot, 0 . \Gamma$ & •, OYY & $v-7$ \\
\hline$\cdot, 0 . r$ & •, OYY & $\Lambda-v$ \\
\hline
\end{tabular}

يتضح من الجدول السابق أن قيم معاملات ثبات إختبار نمو وظائف اللغة بطريقتي ألفا كرونباخ و التجزئة النصفية مقبولة ، مما يثير الي ثبات الاختبار ـ ثبات اختبار نمو وظائف اللغة الصورة المعدلة في الدراسة الحالية : قام الباحث بحساب ثبات اختبار نمو وظائف اللغة الصورة المعدلـــة فــي

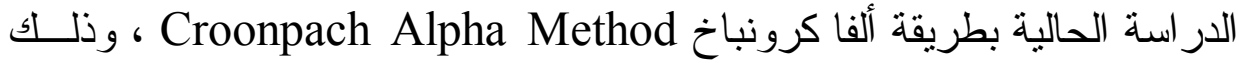

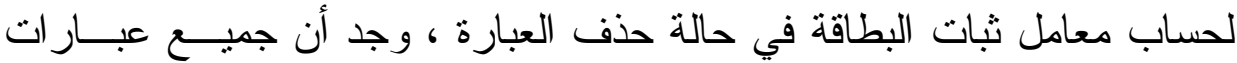

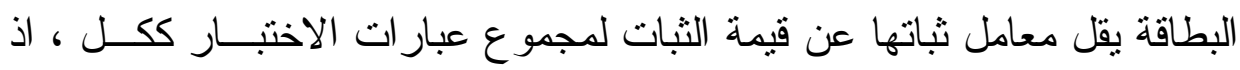




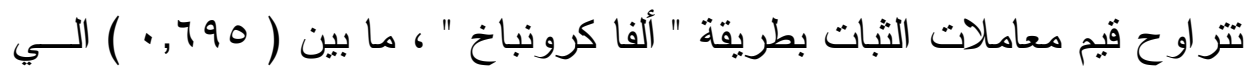

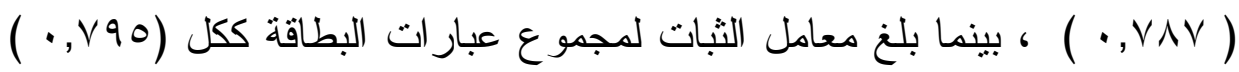

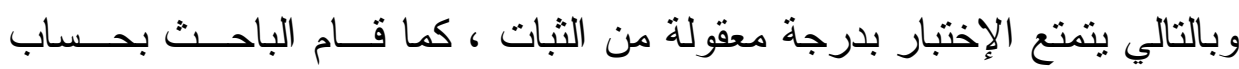

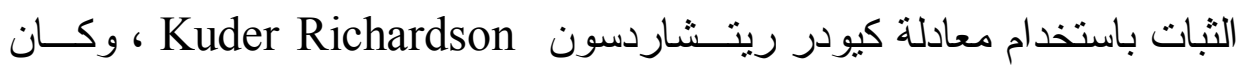

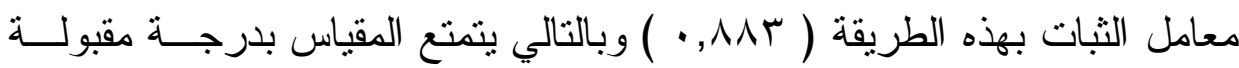

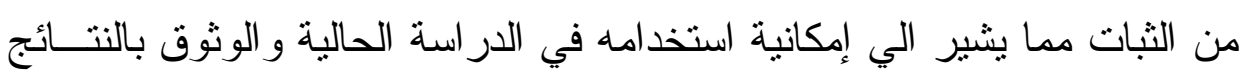

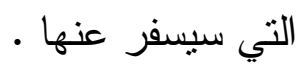

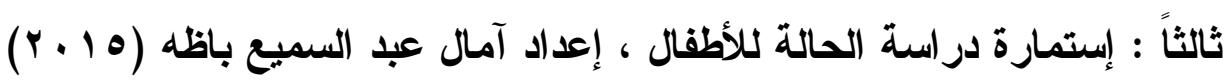
تهدف دراسة الحالة الي النركيز علي الطفل وبيئته وعلاقاته داخل وخارج الأسرة في صورة تطورية ( ماضي - حاضر - مستقبل ) وتعتبر دراسة الحالة

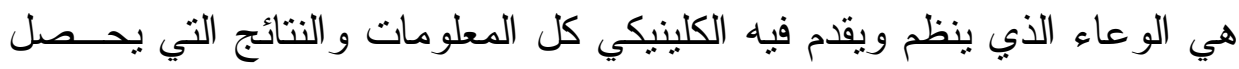

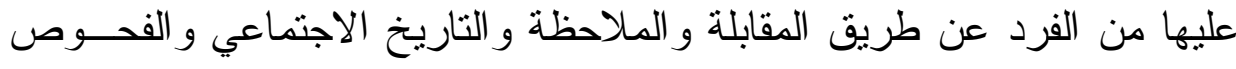

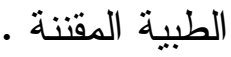

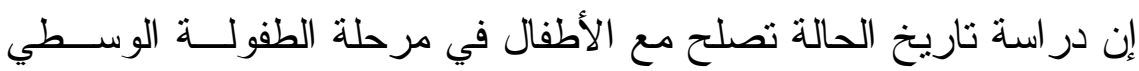

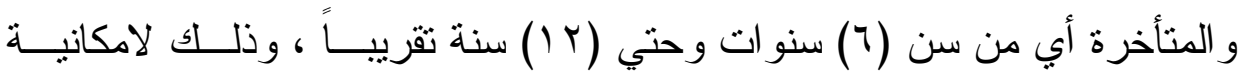

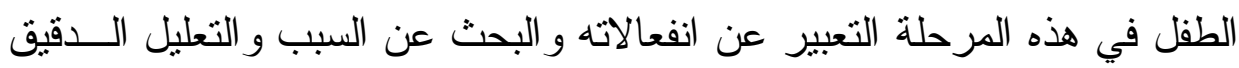

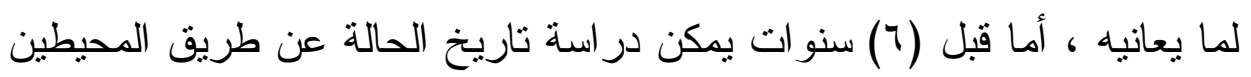

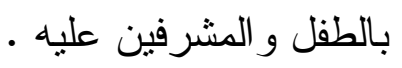
وتتكون إستمارة دراسة الحالة من الأجزاء التالية : أ- جزء خاص بييانات حول الأسرة : جزء خاص بييانات عن الأب وتو اجده وحالته الصحية و النفسية و السمات

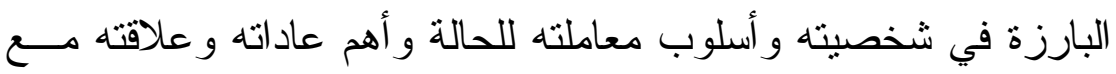


الطفل وفي هذا الجزء تاريخ شامل لحالة الأب و الأم إن وجــــ أو مـن

$$
\text { يشرف علي تربية الطفل . }
$$

• بيانات عن الأم وحالتها الصحية و السمات النفسية السائدة و البارزة لهـــا ،

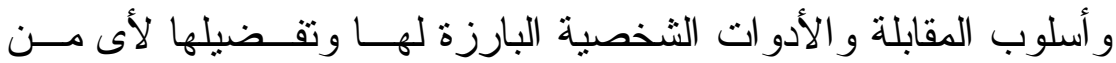

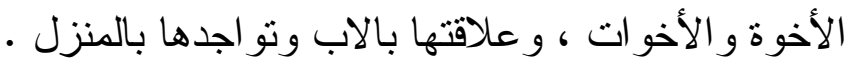

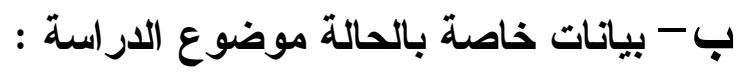
ج- الأخوة والأخوات : وتتشل بيانات خاصة عن عددهم وجنسهم وحالتهم

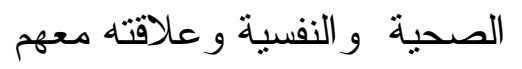
رابعاً : بطاقة الملاحظة : وقد قام الباحث ببناء هذه الأداة بناءًا علي الخطوات التالية :تحديد الهذف من البطاقة

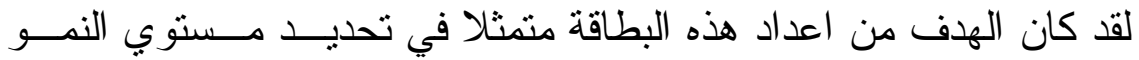

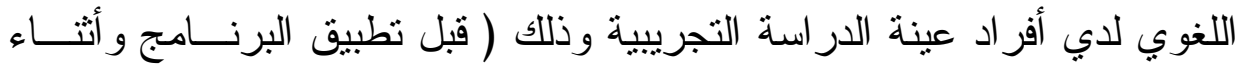

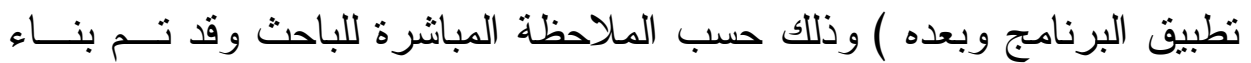

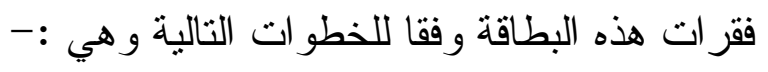
• الاطلاع علي المر اجع التي تتاولت الموضوع و الدراسات و البحوث السابقة

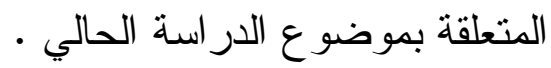
• الاستعانة بآر اء ذوي الاختصاص في مجال علم النفس التربوي و الــصحة

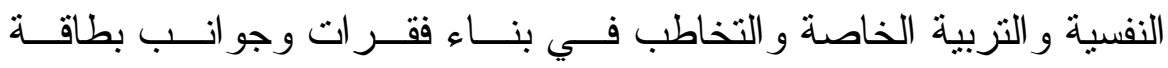
الملاحظة . 
• تحديد المهار ات الرئيسية التي شملتها بطاقة الملاحظة حيث شملت البطاقــة

علي جو انب ثثلاثة هامة وهي ( المستوي الصوتي - المستوي النحــوي -

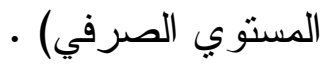

•صياغة الفقر ات التي تقع تحت كل مهارة . • اعداد البطاقة في صورتها الأولية و التي شملت (1 ( ) فقرة . • العمل علي اختبار الخصائص السيكومترية للأداه .

الخصائص السيكومترية لبطاقة الملاحظة :

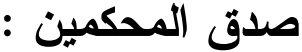

تم عرض بطاقة الملاحظة علي عدد من المحكمين المختصين في مجــال

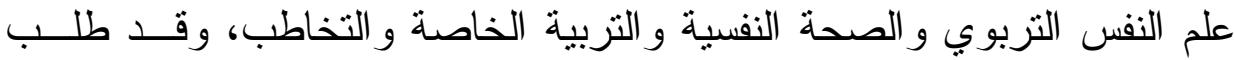
الباحث من المحكمين إبداء وجهة نظر هم حول الأمور التالية :

O مدي ملائمة الفقر ات لمهار ات النمو اللغوي المختلفة .

O مدي تغطية الفقر ات للمهار ات اللغوية المر اد تتميتها ـ O مدي سلامة الصياغة اللغوية للفقر ات . O حذف أو تعديل أو إضافة فقر ات حسب ما يرونه مناسبا . بعد اجر اء التعديلات التي أوصي بها المحكمون تــم حـذف عـدد مــن الفقر ات من بطاقة الملاحظة ، كذلك تم تعديل وصياغة بعض الفقر ات وقد بلـــغ عدد فقر ات بطاقة الملاحظة بعد صياغتها النهائية (0 1) فقرة موزعة علي ثناث مهار ات ، حيث أعطي لكل فقرة وزن مدرج وفق سلم متدرج خماسي ( ممتاز ،

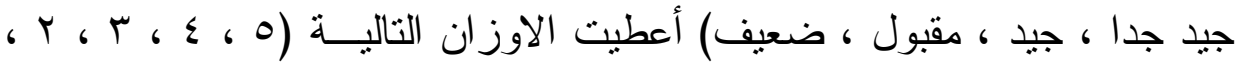
( ) لتقويم مهار ات النمو اللغوي لدي الأطفال المضطربين لغويا 
وقد أجري الباحث في ضوء آر اء المحكمين التعديلات اللازمة ، كما تــم

انتقاء الفقرات التي اتفق المحكمون علي صلاحيتها ،وقد إستبعدت الفقر ات التي أثنار اليها المحكمون ليصبح عدد فقرات بطاقة الملاحظة (0 10) فقرة ، موزعــة علي ثلاث مهار ات عامة هم ( الصوتي ، النحوي ، الصرفي ) ويبين الجــدول (r) توزيع فقر ات بطاقة الماحظة علي مهار ات جو انب اللغة.

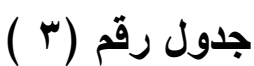

\begin{tabular}{|c|c|c|}
\hline عدد الفقرات بعد الصدق & عدد الفقر ات قبل & المهار ات(الجواتب) \\
\hline 0 & 7 & المستوى الصوتي \\
\hline$\varepsilon$ & 0 & المستوي النحوي \\
\hline 7 & v & المستوي الصرفي \\
\hline 10 & 11 & المجموع \\
\hline
\end{tabular}

خامساً : استمارة المستوي الاجتماعي الاقتصادي للأسرة :-

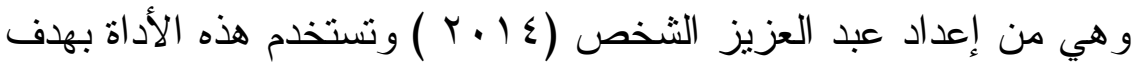

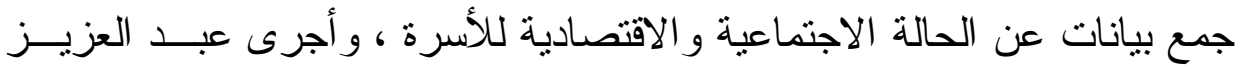
الثخص (9^^1 (1) در اسة استطلاعية و اعد استمارة جمع البيانات عـن الحالــة الإجتماعية / الاقتصادية لبعض الأسر فى ضوء الأبعاد المتضمنة فى الدراسه ، وبلغ عدد الأسر فى العينة (ovo.ov ) أسرة من القاهرة الكبرى ، وتــم اختيــار

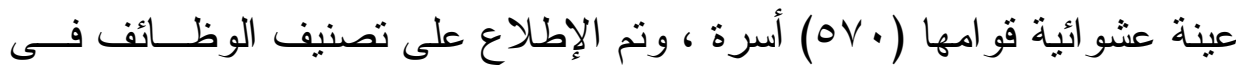
بعض المصالح الحكومية و الجهاز المركزى للتنظيم و الإدارة وحسـساب متوســط دخل الأسرة بالنسبة للعينة العشو ائية المختارة ويمتد من · 1 جنيهات إلى ... . . 
جنية كحد أقصى ، و اتبع فى المقياس تصنيف مستويات الأبعاد المستخدمة فـى تحديد المستوى الإجتماعى / و الاقتصادي على أساس : - بعد الوظيفة أو المهنة (للجنسين) نسعة مستويات - بعد مستوى التعليم (للجنسين) ثمانية مستويات

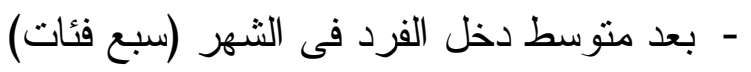
- م المعالجة الاحصائية للمقياس و هكذا يمكن تقدير المستوى الإجتماعى / الإقتصادى للأسرة إستتاداً الـى الـى

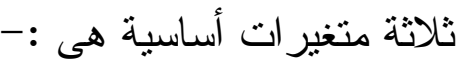

$$
\begin{aligned}
& \text { 1- منوسط دخل الفرد (فى الأسرة) فى الثهر } \\
& \text { r- مستوى تعليم رب الأسرة } \\
& \text { r- ب- بطيفة رب الأسرة }
\end{aligned}
$$

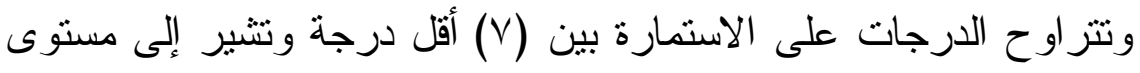

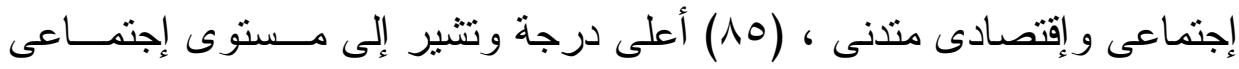

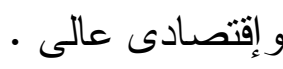

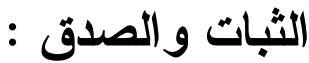

تم تحويل البيانات الخاصة بالمؤشر ات المستخدمة فى تقـدير المسـتوى الإجتماعى / الإقتصادى إلى تقدير ات رقمية وذلك بإعطائها درجات تساوى رقم

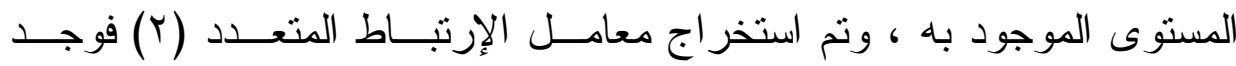

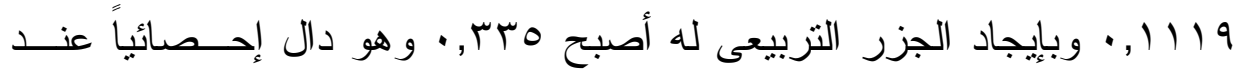

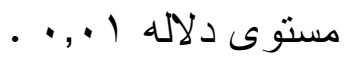


وتم استخر اج قيمة الثابت (أ) وكــذلك معــاملات المتغيــر ات المكونــة

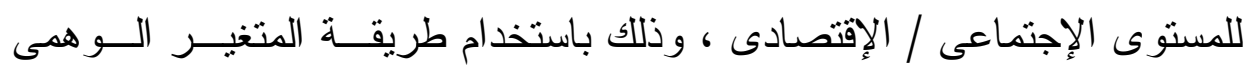
Dummy Variable حساب المعادلة التتبؤية . سادساً : البرنامج القائم على السرد القصصي: بعد الاطلاع على العديد من الدر اسات السابقة التى اهتمت ببناء البــر امج

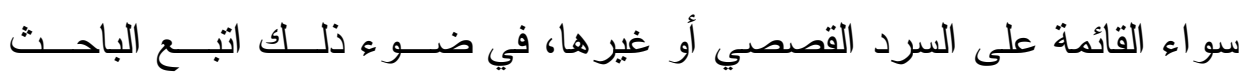
الخطوات التالية في بناء البرنامج: ا ـ المنطلقات الفكرية لإعداد البرنامج.

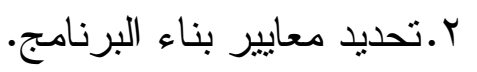
r.تحديد أهداف البرنامج. ع.تحديد الطر ائق و الوسائل التطبيقية لتتفيذ البرنامج. ه. اختيار الوسائل المناسبة في تتفيذ البرنامج. 7 ا الخطة الزمنية المتوقع فيها تتفيذ البرنامج كاملا. V التقويم البرنامج. المنطلقات الفكرية لإعداد البرنامج: استتد الباحث إلى عدة منطلقات فكرية و أسس فلسفية وعمليــة لتـصميم البرنامج ومن أهمها: ا. استخدام إستر اتيجية السرد القصصي لتتمية اللغـــة لــى المــضطربين لغويًا. 
r. التركيز على السرد القصصي و أهيته في حياة الطفل بشتى الدجـالات،

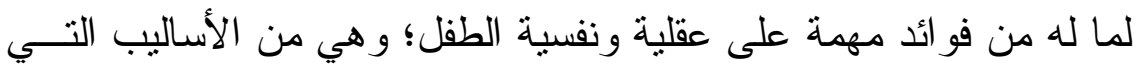
تجذب اهتمام الطفل ، وتثير إنتباهه.

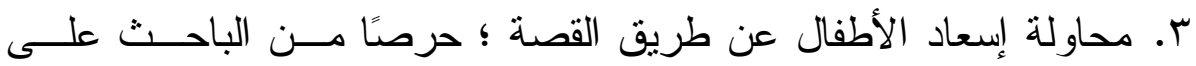

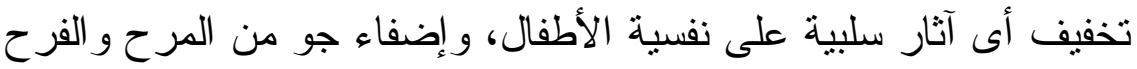

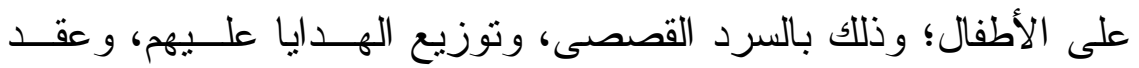
الاحتفالات المميزة، ومشاركتهم بها. ع. استخدام الدمي و المسرح من أجل إثر اء الدفردات اللغوية لاى الطفل مسنـ خلال سرد القصص، و المسرحيات الهادفة. 0. الاهتمام بالنشيد و الأغاني في القصص المختارة. T. وصف الصور الثابتة و المتحركة من خلال القصص. معايير بناء البرنامج الإرشادي:

في ضوء منطلقات بناء البرنامج تم الاستتاد على عدة معايير فــي بنـــاء

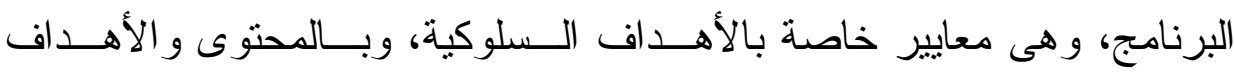
النطبيقية و التقويمية.

أ- المعايير الخاصة بالأهداف السلوكية: عند صياغة الأهداف السلوكية للبرنامج الارشادي راعى الباحث مايلي: ا أن يكون الهدف محددًا تحديدًا دقيقًا.

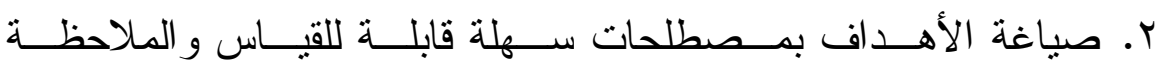

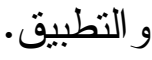


ب- المعايير الخاصة بالمحتوى القصصي : عند بناء البرنامج الارشادي تم مر اعاة مايلي: ا ـ يشمل المحتوى على أنشطة متتوعة و ألعاب لغوية مختلفة وملائمة لفهر الأطفال ومسايرة لأطو ار نموهم • لإن r • ير اعي المحتوي القصصي التـدر ج ليناســب مـسـتوي الأطفــال ذوي الاضطر اب اللغوي وأن يكون متسلسل للأحداث متماسك الأجز اء. r. لغة المحتوى القصصي سهلة وو اضــحة، ونتاســب مـستوى أطفــال المرحلة وفي نطاق المحصول اللغوي للطفل ولها هدف تربوي وتـسهم في تتمية قدر ات الطفل اللغوية .

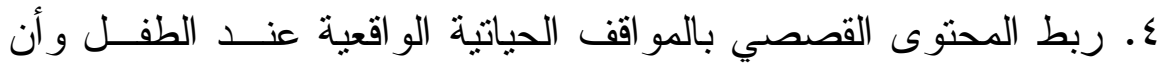
تكون شخصيات المحتوي مألوفة لعالم الطفل ، قليلـــة قــدر الإمكــــان و اضحة في معالمها . ه. تتضمن الثخصيات أبطال يشبهون الطفل في العمر و القــوة ، ليتوحــــ

$$
7 \text {. } 1 \text {. يكون الحوار جذاب وسلس }
$$

V. تتتهي القصة نهاية سعيدة عادلة "تكافئ الخير وتعاقب الثر" . ^. الحلول التي تقدمها القصة حلول بناءة ومقبولة و عملية . 9. تشجيع الطفل على التعبير و المـشـاركة فـي الأنـشطة ، فــالمحتوي يحتوي علي أنشطة تجذب اتتباه الطفل، وتثير القدرة التعبيريـــة لــدى الطفل. 
ج- - المعاييز الخاصة بإستر اتيجيات التطبيق:

عند إعداد البرنامج الارشادي تم مر اعاة ما يلي من جانب المعلم: ا ـ التعرف على خبر ات الأطفال السابقة. r. تعريف الأطفال بالهدف من القصه، و المهار ات التي يجب أن يكتـسبها في نهاية القصة. r. الربط بين معرفة الأطفال السابقة بمفاهيم القصه وبالمعرفة الجديدة. ء. مناقتشة صور القصه و التعبير عنها بجمل مفيدة ه. عرض القصه على الأطفال بأسلوب السرد القصصي. 7. قر اعة القصه قر اعة جهرية ممثلة للمعنى. V. قر اعة القصه على هيئة فقر ات موزعة على الأطفال حسب المستويات

$$
\text { (التحصيلية و العقلية) }
$$

^. مناقتشة القصه شكلاً ومضموناً بهدف التعرف على مدى إتقان الأطفال لمهار ات اللغة. 9. توفير البيئة المناسبة لسرد القصة ومحاكاتها مع الأطفال، وذلك بتتـوع المكان في كل جلسة ، و ان ثتو افر فـي الأنسشطة المــصاحبة للـسرد القصصي عامل الأمن و السلامة . • 1. تقديم تغذية راجعة فورية ومستمرة ، وذلــلك بــابر از نقــاط القــوة و الضعف أثناء الأداء مع تثبيت وتدعيم الأنماط السلوكية الــصحيحة وتصحيح الأنماط السلوكية الخاطئة وتعــديلها حتـي يتحقـق الأداء المطلوب مما يثتبه ويدفعه الي تكر ار نفس السلوك أو الموقف 1ا. تشجيع الأطفال على التعبير دون الثعور بالخوف أو الارتباك. 
r ا. التدرج من السهل إلى الصعب في تطبيق جلسات السرد القصصي.

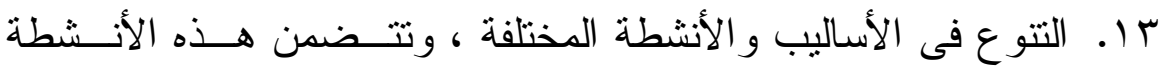
قصص تدور حول الإر ادة و الصبر و المثابرة ومساوئ افتقاد الطفــلـل للغة و التعاطف مع الآخرين و الحرص علي العلاقــة بهــم ، و القبــام

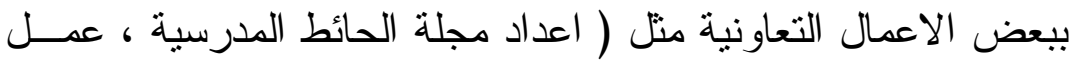
اللوحات، تزيين الفصل بالإضافة الي الأناثشيد و الاغاني الجماعيــة )

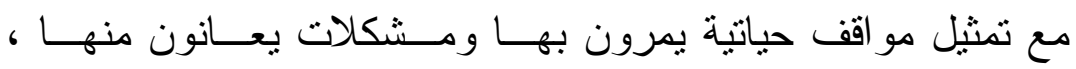
و المو اقف التي سيو اجهونها في المستقبل وكيفية التصرف حيال هــــه

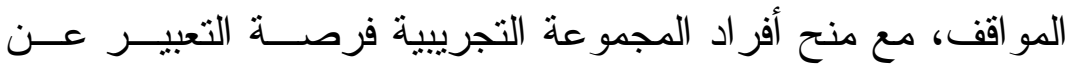

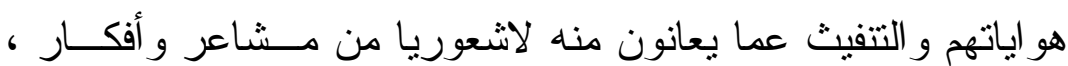

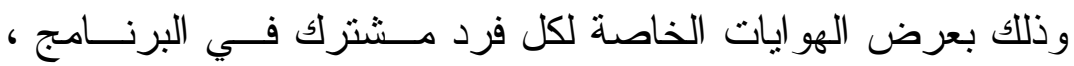

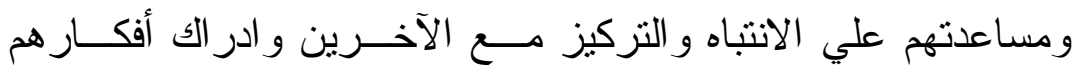

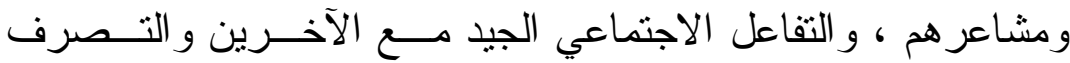

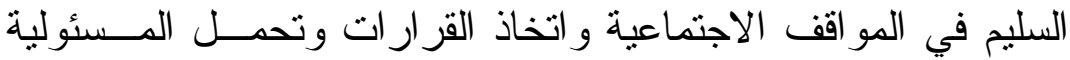

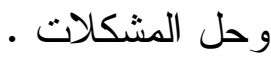

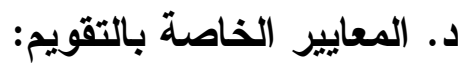

تأكد الباحث من مدى تحقيق الهذف من كل جلسة فى النهاية، كمـــا قـام

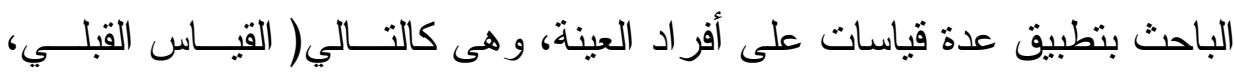

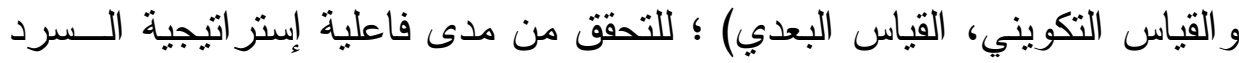
القصصى في تتمية اللغة لاى الأطفال المضطربين لغويًا. 


\section{+ تعديد أهداف البرنامج :

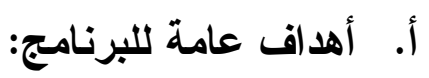

ا.تتمية المستوى الصوتي للغة لاى الأطفال المضطربين لغوياً.

r.تتمية المستوى النحوي للغة لدى الأطفال المضطربين لغوياً.

r.تتمية المستوى الصرفي للغة لدى الأطفال المضطربين لغوياً.

\section{وتتحقق هذه الأهداف من خلا:}

ب. الأهداف الخاصة الآتية:

• خفض الاضطر ابات اللغوية المصاحبة للأطفال فـي مرحلـــة الطفولـــة

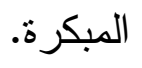

• الوصول بمستوى الأداء اللغوي لدى الأطفال إلى أفضل وضع ممكن.

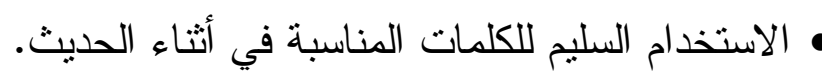

• تصحيح الأخطاء اللغوية الثفوية و الكتابية لدى الأطفال.

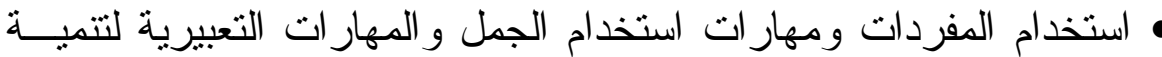

اللغة لدى الأطفال المضطربين لغويًا.

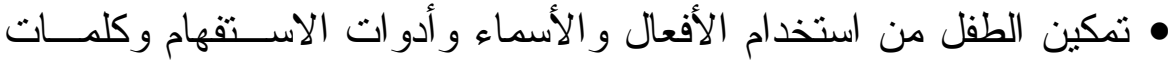

الرفض و الثلك و اليقين و التذكر و الوصف و التمييز ، مما بسهم في تتميــة

اللغة سو اء الاستقبالية أو التعبيرية ويكسبه القدرة علي التعبيــر و الحــــوار

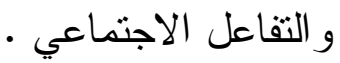

• تتمية القدرة التعبيرية لدى الطفل من خلال عرض القصص و الحكايـات

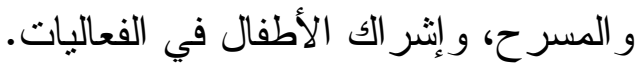


إمتاع وتسلية الطفل من خلال تتـوع الأنـشطة و التعزيــز ات المقدمــة للأطفال المصاحبة للإستر اتيجية ، مما يسهم في رعايتهم نفسيا من خلال مشاركة مشاعر هم في الأنثطة التي يحبونها ، وتقبلهم في جميع حسالاتهم النفسية و انثباع حاجاتهم و التفاعل و التو اصل معهم لتحقيق النمو النفسي لنسي • السليم

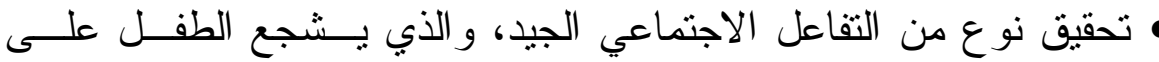
التحدث بطلاقة مع الآخرين ، من خلال تدعيم العلاقات و التفاعلات بـين الأطفال عينة الدراسة خلال الجلسات ، مما يدفعهم الي توظيف طاقـاتهر وتتمية هو اياتهم ومو اهبهم ، وتتجيعهم علي ابــراز قـــرتهم الإبداعيــة

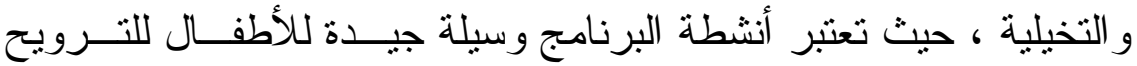
و التتفيث عن رغباتهم • الوسائل المادية المستخدمة في تنفيذ البرنامج: الأدوات المستخدمة في تطبيق البرنامج متنوعة منها: ا. صور ملونة لمناظر طبيعية، ومواقف حياتية و أدو ات وأجهـزة مختلفــة متتو عة و عدد من الصور المتطابقة و المختلفة. r. أقلام ملونة ولوحات ورقية وسبورة. r. أدو ات منزلية ومكتبية متتو عة. ؛. جهاز الكمبيوتر، و الاسطو انات المتعلقة بالقصص التعليمية.

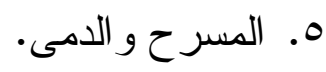
1. . مجسمات للفو اكه و الأثكال و غير هم. 


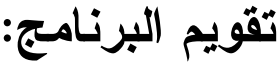

في ضوء أهداف البرنامج استخدم الباحث أساليب التقويم التالية:

ا ـ التقويم القبلي: وذلك من خلال تطبيق كلاً من اختبار نمو وظائف اللغة،

و بطاقة الملاحظة قبل البدء في تتفيذ البرنامج.

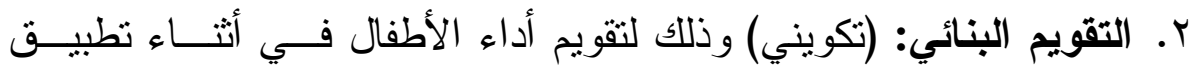

البرنامج، ومعرفة ددى تفاعلهم، ومدى الإستفادة، و التغير الطارئ عليهم؛

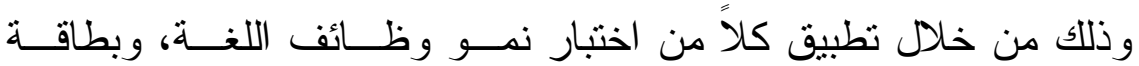

الملاحظة في أثناء عقد الجلسات الإرشادية.

r. التقويم البعدي : حيث نم تطبيق كلاً من اختبار نمو وظائف اللغة وبطاقة

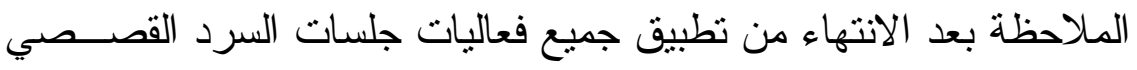

لبيان مدى فاعلية البرنامج وثباته.

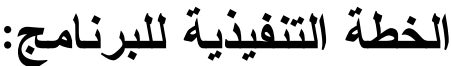

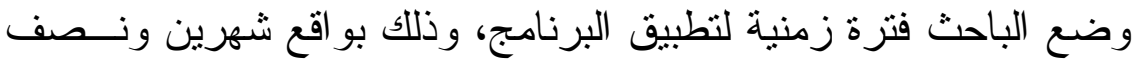

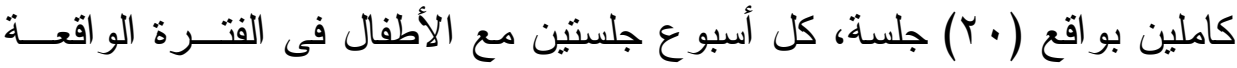

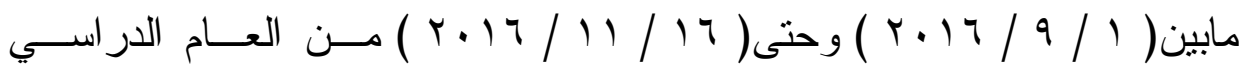

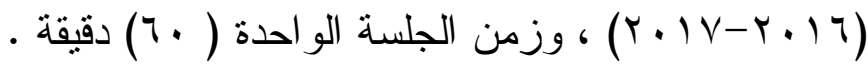

تحديد مراحل إعداد وبناء البرنامج:

قام الباحث بتصميم و إنتاج برنامج بهدف تتميـــة اللغـــة لــدى الأطفــال

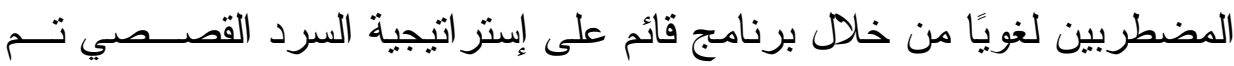

$$
\text { بناؤه بناء على خطو ات ومر احل منها: }
$$

ا ب. صياغة الأهداف العامة و الخاصة للبرنامج المستخدم:

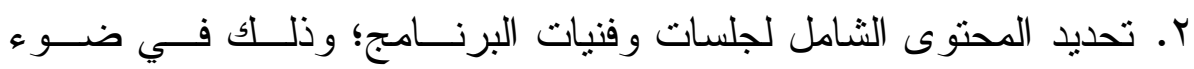

الأهداف المصاغة حيث شمل البرنامج على ما يلي: 
جدول (๕)

\begin{tabular}{|c|c|c|}
\hline الجلسات & المهارات التي ستنميها القصة & القصة \\
\hline$\varepsilon$ & 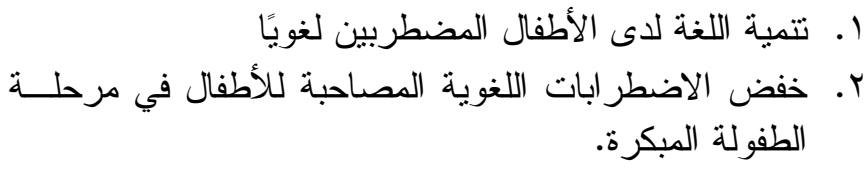 & الأولى \\
\hline$\varepsilon$ & 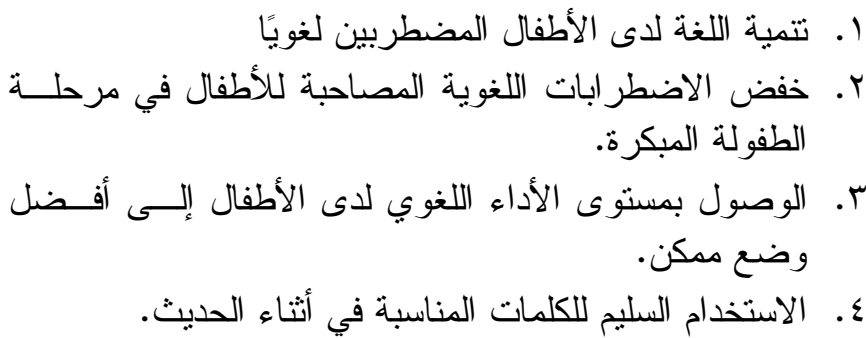 & الثانية \\
\hline$\varepsilon$ & 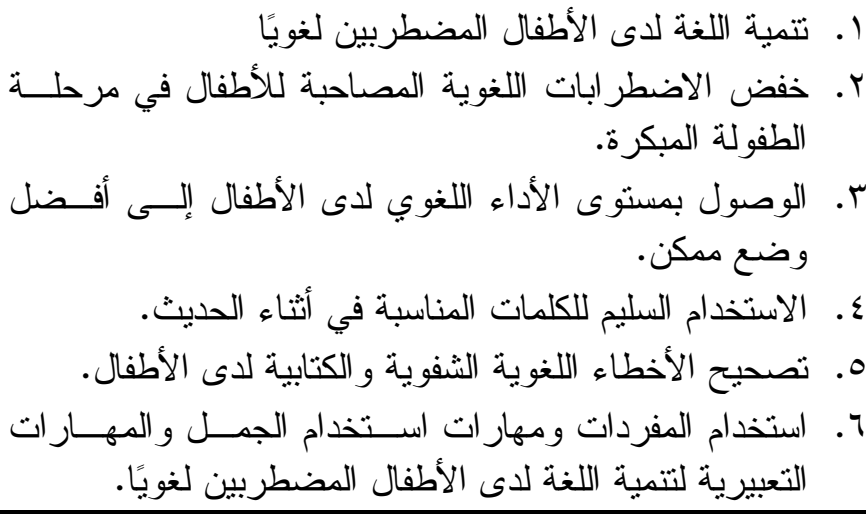 & الثالثة \\
\hline$\varepsilon$ & 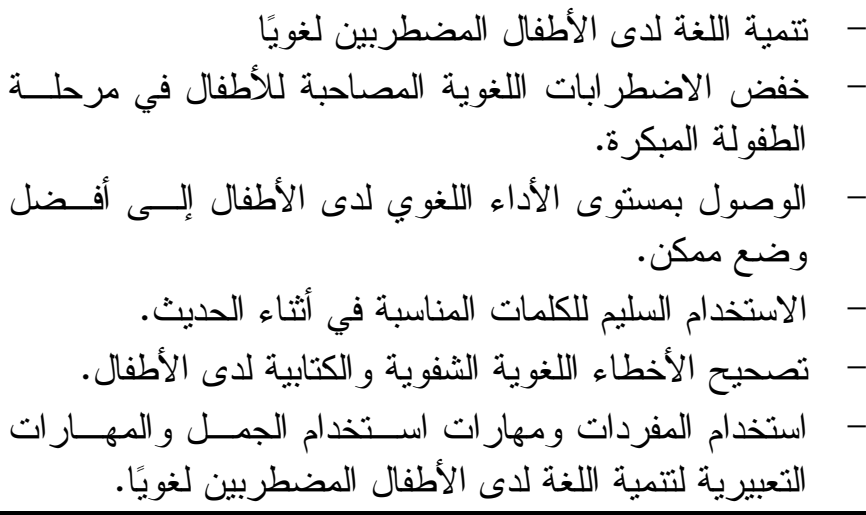 & (1) \\
\hline
\end{tabular}




\begin{tabular}{|c|c|c|c|}
\hline \multirow[t]{2}{*}{ الجلسات } & \multicolumn{2}{|l|}{ المهارات التي ستتميها القصة } & القصة \\
\hline & 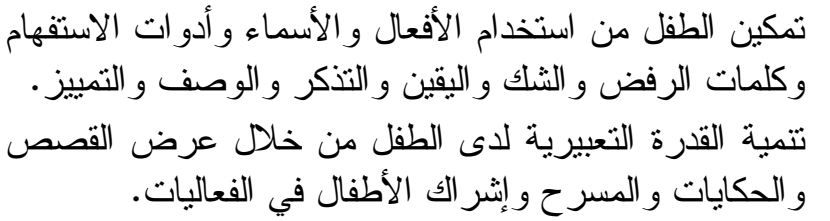 & - & \\
\hline$\varepsilon$ & 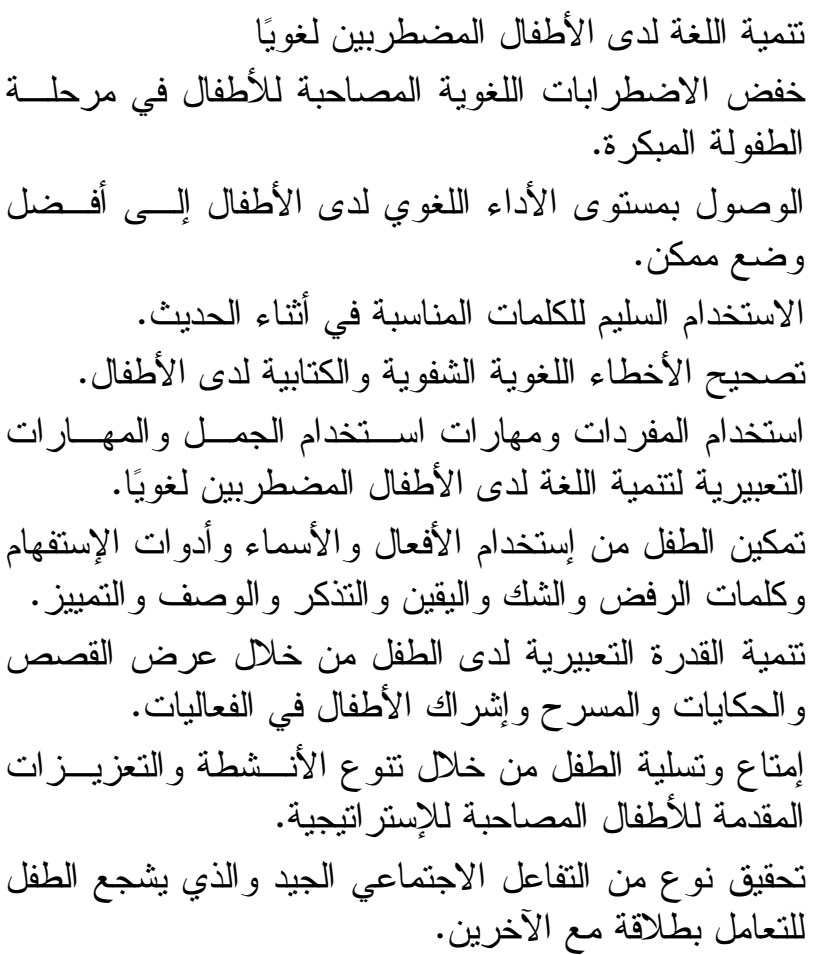 & - & الخامسة \\
\hline
\end{tabular}

r. تحديد الوسائل التعليمية: التى ينبخي أن بتضمنها البرنامج و المتمثلة فـى

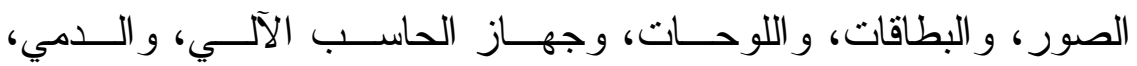

$$
\text { و المجسمات، و المسر ح: }
$$

ع. تحديد وسائل التعزيز و أنماطه المختلفة.

○. تحديد أساليب التقويم المناسبة لتحديد مواطن الضعف والقوة وتتمية اللغة

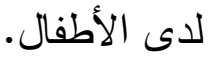


صدق البرنامج:

بعد أن تم بناء البرنامج ووضعه في صورته الأولية، ومن أجـلـ التأكــــ من سلامته، وصلاحيته للتطبيق؛ وتم عرضه علي (V) مسـن المحكمـين مـن أعضاء هيئة التدريس في مجال علم النفس التزبوي و الصحة النفـــية و التزبيـــة الخاصة ، وذلك للتحقق من مدي ملائمة البرنامج للهدف الذي وضع من أجله ، وخصائص و احتباجات ومطالب الأطفال المضطربين لغويا في هذه المرحلة من

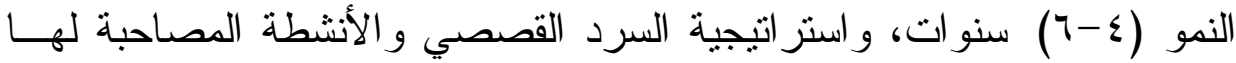

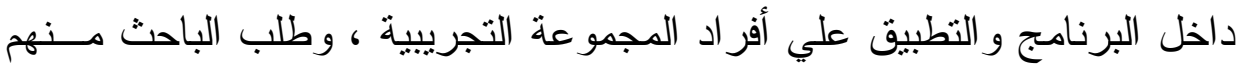

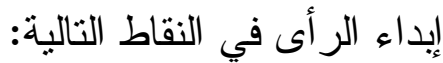

مدى ملائمة البرنامج للأهداف العامة، و الخاصة. مدى سلامة الصياغة اللغوية، و الأنشطة اللغوية من الأخطاء.

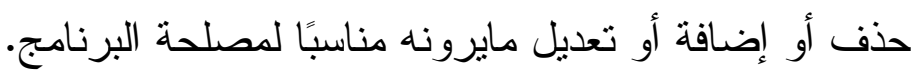

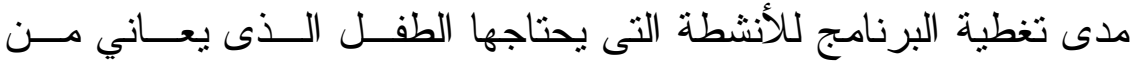
الاضطر اب اللغوي.

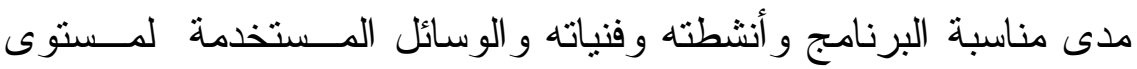

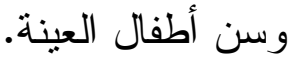
وقد قام الباحث بالتعديلات المطلوبة، وبذلك أصبح البرنامج يتتمع بصدق

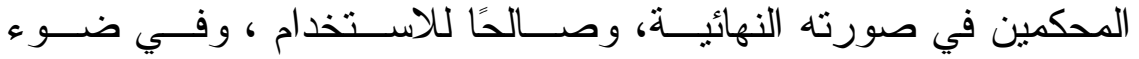

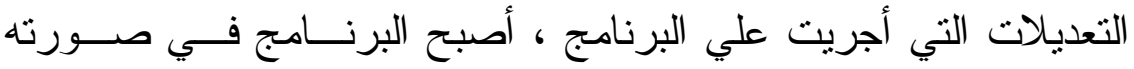

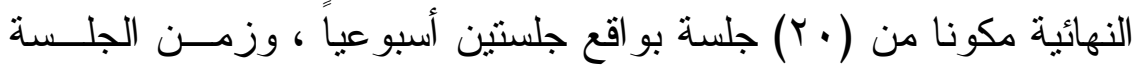

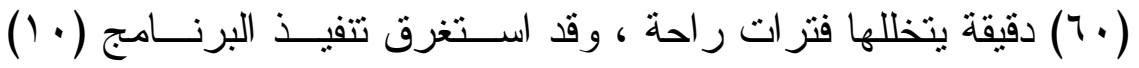

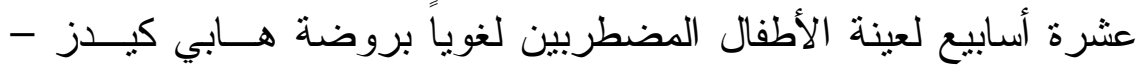

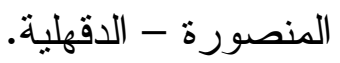




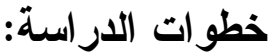

•تم الاتفاق مع مديرة روضة هابي كيدز علــى تطبيـق البرنــامج ومدتــه، وضرورة توفير مكان مخصص لتطبيق البرنامج.

•تم اختيار عينة الدراسة من الأطفال الذين يعانون من الاضطر الابات اللغوية،

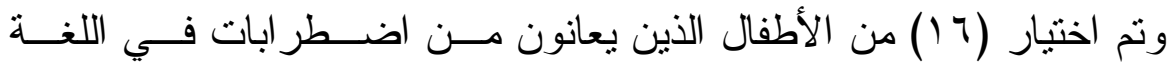

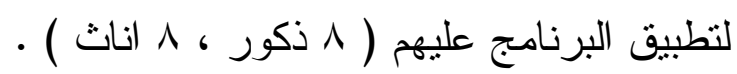

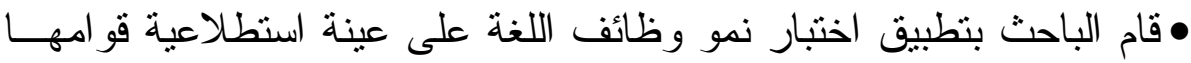
(10 ) طفل للنأكد من صدق وثبات الأداة المستخدمة.

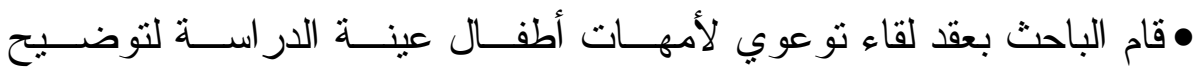

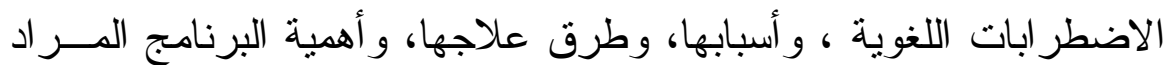

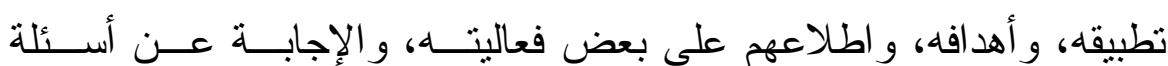

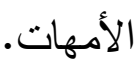

• قام الباحث بتطبيق اختبار نمو وظائف اللغة القبلى، وبطاقة الملاحظة على الى عينة الدر اسة قبل تطبيق البرنامج.

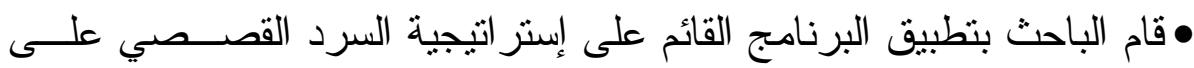

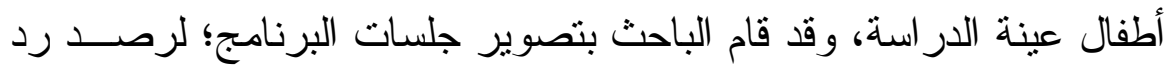

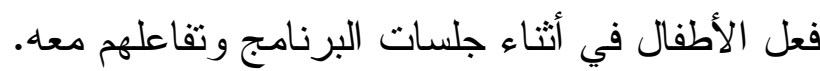

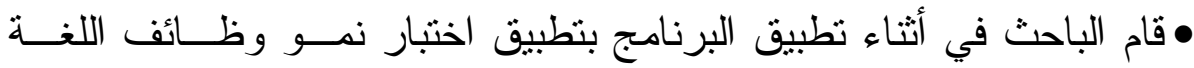
التكويني، وبطاقة الملاحظة على عينة الدراسة.

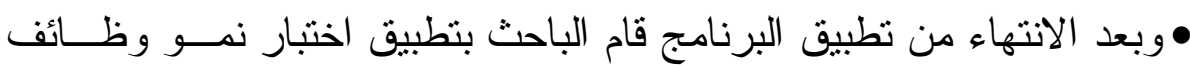
اللغة البعدي ، وبطاقة الملاحظة على أطفال عينة الدراسة. • قام الباحث في نهاية الدر اسة بتحليل النتائج ومناقتشتها.

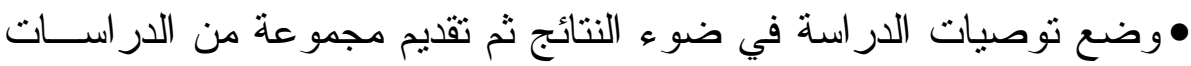

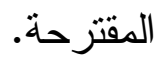


الأساليب الإحصائية المستخدمة:

اعتمد الباحث في دراسته على المعالجات الإحصائية الآتية: • النسب المئوية و التكر ار ات.

• المتوسطات الحسابية و الانحر اف المعياري. • تحليل التباين للقياسات المتعددة

• معامل الثبات ألفا كرونباخ و التجزئة النصفية.

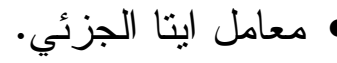

نتائج الدر اسة ومناقثتها:

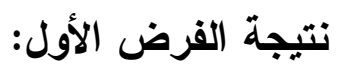

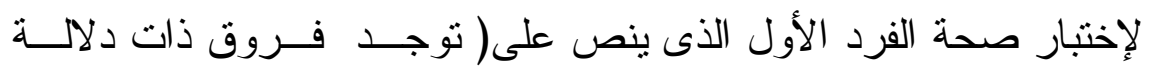
إحصائية في متوسط درجات الاضطر اب اللغوي حسب القياسات المتعددة(قبلى، تكويني، بعدي) فى اختبار نمو وظائف اللغة لدى الأطفال المضطربين لغويَّا)،

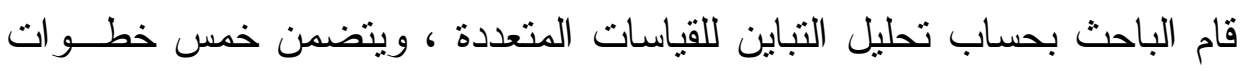
متسلسلة هي:

ا ـ المساب المعالم الإحصائية للمتغير ات. r. التأكد العام من وجود فروق. r.حساب شرط الدورية. ع. حساب التباين المتعدد. هـ اختبار المقارنات البعدية لمعرفة اتجاهات الفروق. فجاءت النتائج على النحو التالي: 
جدول (0)

يوضح المعالم الاحصائية للقياسات المتعددة على

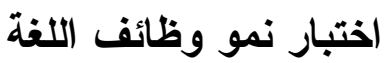

\begin{tabular}{|c|c|c|c|}
\hline عدد الحالات & الانحر افت المعياري & المتوسط الحسابي & القياسات \\
\hline 17 & $\varepsilon, .0 \mathrm{~V}$ & $r_{0,9} \leq$ & القياس القبلي \\
\hline 17 & $7,9) \vee T V$ & $\varepsilon r, 1$ Y O. & القياس النكويني \\
\hline 17 & $0, A Y q 0 \mathrm{r}$ & $\varepsilon q, r \vee O$. & القياس البعدي \\
\hline
\end{tabular}

وللتأكد من وجود فروق دالة إحصائيًا بين القياسات المتعددة فـي اختبــار

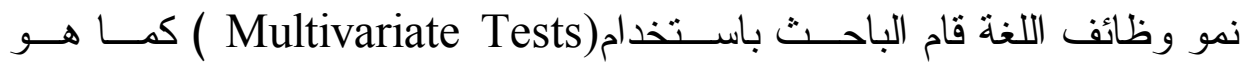

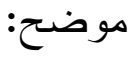

جدول(7) (7)

يوضح الدلالة العامة للفروق بين القياسات المتعددة لاختبار نمو وظائف اللغة

\begin{tabular}{|c|c|c|c|c|c|}
\hline الاحتمالية & نسبة الخطأ & الحرجية & قيمة f & قيمة sig & التأثير \\
\hline$\ldots$ & $1 \varepsilon, \ldots$ & $r, \cdots$ & 19,TY & אדי, & اختبار و الكس لمبادا \\
\hline
\end{tabular}

يتضح من الجدول السابق مستوى الدلالة لمعامـل (F) حسب اختبـار

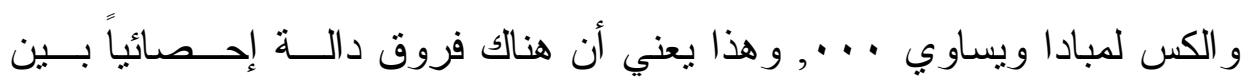
القياسات المتعددة الثلاثة في اختبار نمو وظائف اللغة، الأمر الذي يتيح استكمال باقي إجر اءات التحليل. 
جدول (v)

يوضح نتائج اختبار شرط الدورية (Mauchlys Test of Sphericity)

\begin{tabular}{|c|c|c|c|}
\hline مستوى الدلالة & درجة الحرية & 2k معامل & معامل الدورية \\
\hline, $0 \leqslant r$ & r & $1, Y Y T$ & ,917 \\
\hline
\end{tabular}

وبناءً على ماورد في الجدول السابق يتضح لنا أن مستوى الدلالة لمعامـل

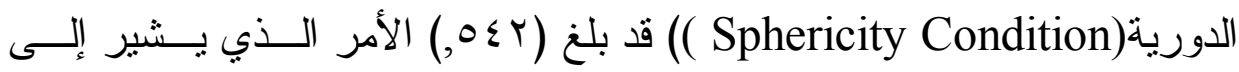

تحقق شرط الدورية، وعليه فإن الباحث سيعتمد علـي معامـل Sphericity) عند اختبار الفروق بين القياسات المتعددة، وقد جـــاءت النتيجـــة Assumed)

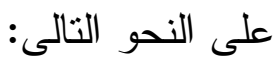

جدول) (^)

يوضح النتائج التفصيلية للفروق في القياسات المتعددة لاختبار نمو وظائف اللغة

\begin{tabular}{|c|c|c|c|c|c|c|}
\hline مربيع معامل الجزئي & الاحتمالية & معامل F & المربعات & الاححراف & المتوسط & القياس \\
\hline \multirow{3}{*}{ וT } & \multirow{3}{*}{,$\cdots$} & \multirow{3}{*}{$T \varepsilon, 00 \mathrm{~V}$} & \multirow{3}{*}{$1 \leqslant \varepsilon\rceil, \wedge \vee 0$} & $\varepsilon, .0 V$ & $r_{0,9} \leq$ & القياس القبلي \\
\hline & & & & $7,91 \mathrm{~V}$ & $\varepsilon r, 1$ Y O. & التكويني \\
\hline & & & & $0, \wedge r q$ & $\varepsilon q$, r $\vee$. & القياس البعدي \\
\hline
\end{tabular}

وبناءً على ما ورد في الجدول السابق اتضح وجود فروق بين القياسـات

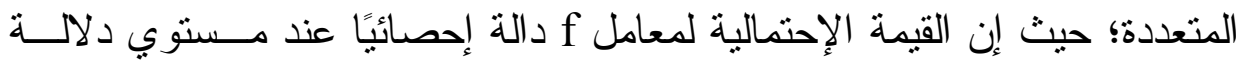
( · , ) ) ، للتأكد من اتجاه الفروق قام الباحث بإجر اء حساب المقارنات المتعددة فجاءت النتائج على النحو التالي: النياه 


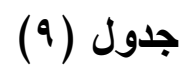

\begin{tabular}{|c|c|c|c|}
\hline القيمة الاحتمالية & الخطأ المعياري & متوسط الفروق & العو امل \\
\hline,$\cdots \wedge$ & 1,997 & $\vee, \backslash \wedge \Lambda-$ & القياس القبلي- التكويني \\
\hline,$\cdots$ & $r, 1 \cdot r$ & $\mid r, \varepsilon r \wedge-$ & القياس القبلي_ البعدي \\
\hline,$\cdots$ & r,TrV & Yo., T- & القياس التكويني-البعدي \\
\hline
\end{tabular}

ويوضتح الجدول السابق وجود فروق دالة إحصائيًا بــين القبـــس القبلــي

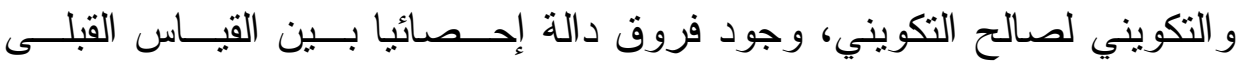

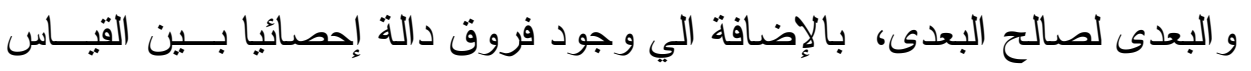

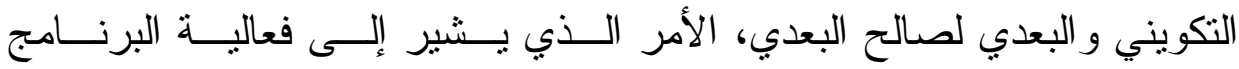

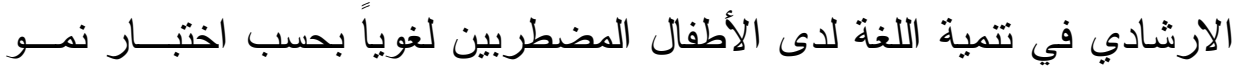
وظائف اللغة.

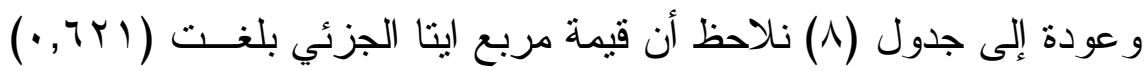

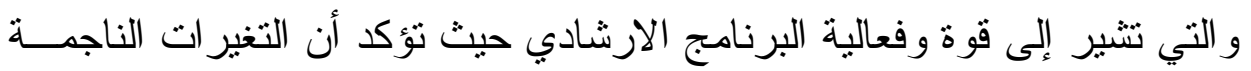
عن البرنامج جوهرية، وليست ظاهرية.

ويرجع الباحث أن هذا التحسن يرجع الي اثتر الك و انتظام أفراد المجموعة

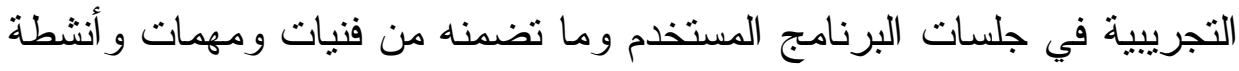

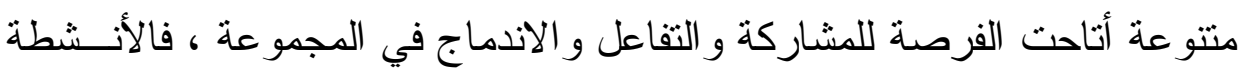

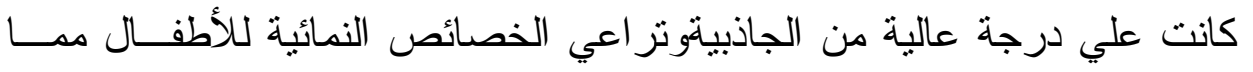

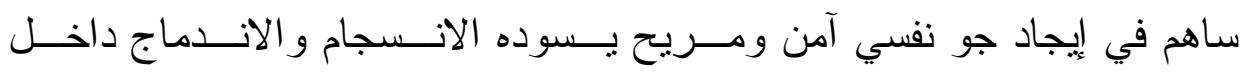
المجموعة ، حيث أن الثفاعل الاجتماعي أي الاخذ و العطاء و التأثنير المنبادل بين

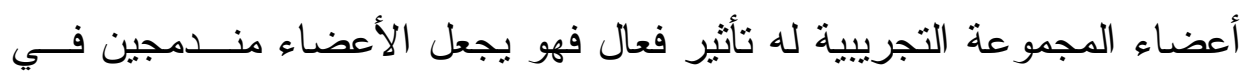


أنشطة البرنامج ويصبح للارسال و الاستقبال الاجتماعي تأثثر ارشادي ملهـوس

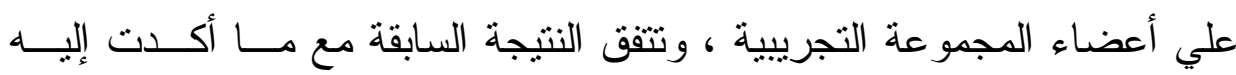
الدر اسات النفسية و التزبوية الي ضرورة الاهتمام ورعاية هذه الفئة من الأطفــال المضطربين لغويًا بالنسبة لأقر انهم العاديين ، ومما لاثكك فيه بأن تحقيق الاهتمام

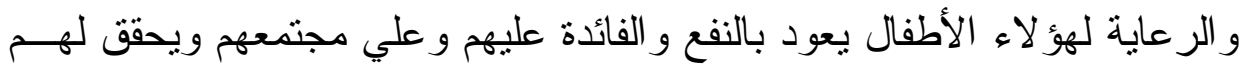

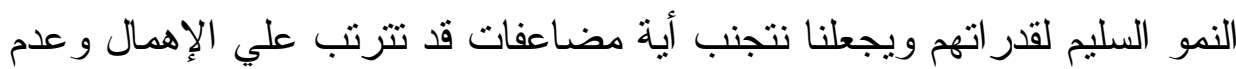
Weiss , N , 2007 , Laura , M , 2007 , Rubin, M , 2005 , ) الرعاية

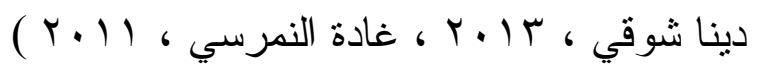

فالعلاقة بين المشكلات اللغوية و النو افق النفسي و الاجتماعي علاقة منبادلة

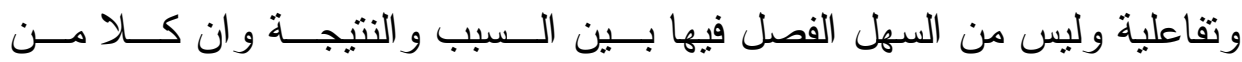
المشكلات اللغوية ومشكلات التو افق قد يكونان نتائج ومؤثرات لعو امــل بيئيـــة

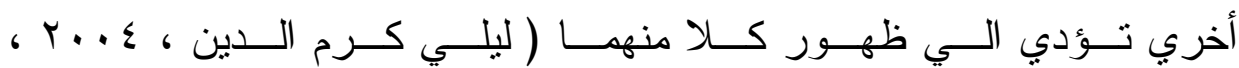
• ( Bridge , B , 2010 ، Fritz\&Richler , 2012

فإعاقة عملية التو اصل بين الطفل المضطرب لغويًا وبين الآخرين ينرتــب

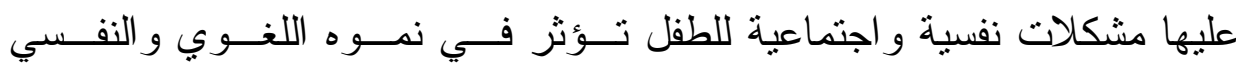

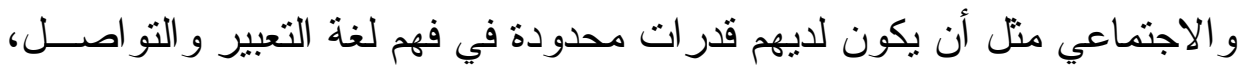
ولديهم تتوع محدود في التعبيرات اللفظية التلقائية، وقصور في اللغة التعبيريــة،

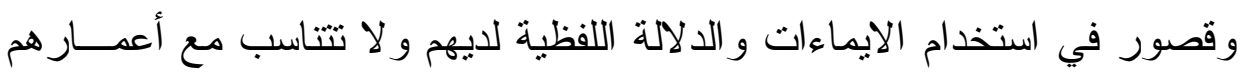

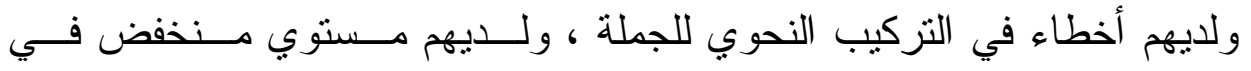

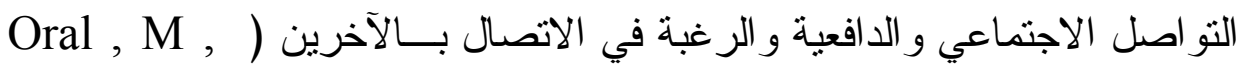
• (2012 , Paul , M , etal , 2011 , Abbey , N , 2009 
عرض نتيجة الفرض الثاني:

لاختبار صحة الفرض الثاني الذي ينص على (توجد فــروق ذات دلالــــة

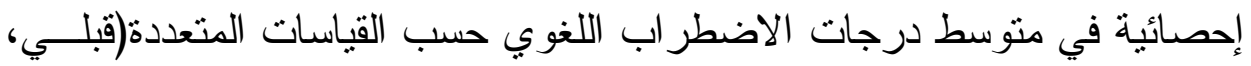

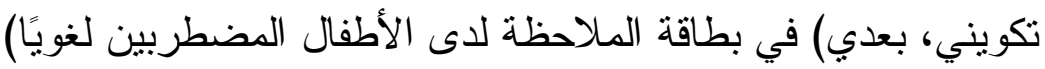

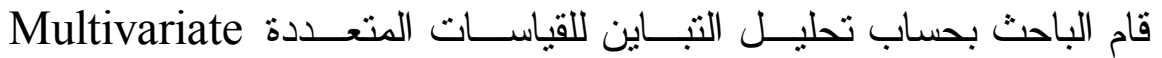

ف فاءت النتائج على النحو التالي: (Repeated Meagers)

$$
\text { جلول (1.) }
$$

يوضح الدلالة العامة للفروق بين القياسات المتعددة على بطاقة الملاحظة

\begin{tabular}{|c|c|c|c|c|c|}
\hline الاحتمالية & نالخطأ & لدرجة & قيمة" & قيمة sig & التأثير \\
\hline,$\cdots$ & $1 \leqslant, \ldots$ & $r, \ldots$ & $11, r r \varepsilon$ &, .09 & اختبار و الكس لبعبادا \\
\hline
\end{tabular}

يتضح من الجدول الـسابق مسستوى دلالــة قيهـة (f) و التـــي تـساوي

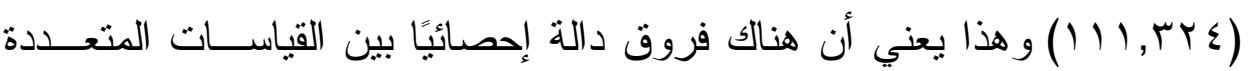

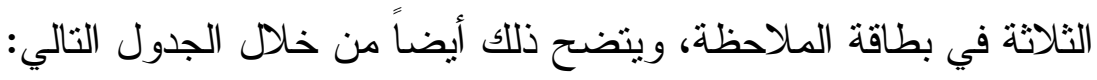

جدول(1)

يوضح نتائج اختبار شرط الدورية(Mauchlys Test of Sphericity) دعائة

\begin{tabular}{|c|c|c|c|}
\hline مستوي الدلالة & درجة الحرية & معامل2K & معامل الدورية \\
\hline, 910 & $r$ & •r. &, 991 \\
\hline
\end{tabular}

وبناءً علي ماورد في الجدول السابق يتضح لنا أن مستوى الدلالة لمعامل

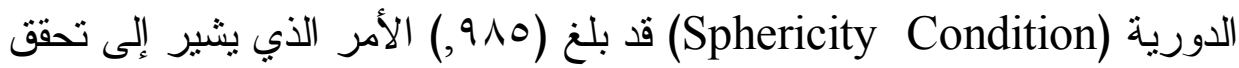

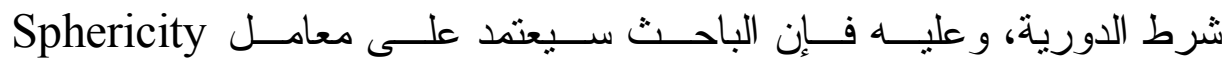

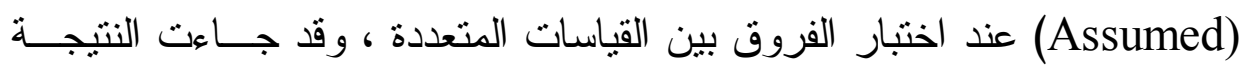
على النحو التالي: - (A) 


\section{جلول (r ا )}

يوضتح النتائج التفصيلية للفروق في القياسات المتعددة لبطاقة الملاحظة

\begin{tabular}{|c|c|c|c|c|c|c|}
\hline مربتا الجزئي معامل & الاحتمالية & معاملf & المربعات & الانحر اف & المتوسط & القياس \\
\hline \multirow{3}{*}{, А९r } & \multirow{3}{*}{,$\cdots$} & \multirow{3}{*}{$1 Y r, 011$} & \multirow{3}{*}{ I } & $11,7 \leqslant \leqslant \vee \leqslant$ & $r r, \ldots$ & القباس \\
\hline & & & & 11, & $\leqslant \Psi, \wedge \mid Y_{0}$ & التكويني القياس \\
\hline & & & & $\Lambda, I Y \backslash \vee T$ & $\neg r, \neg \wedge \vee 0$ & البعدي \\
\hline
\end{tabular}

وبناءً على ماورد في الجدول السابق اتضح وجود فروق بـين القياســات

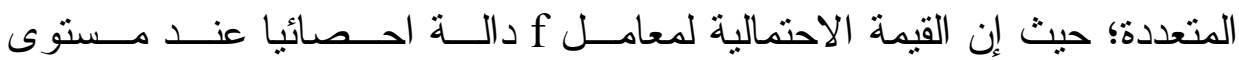
دلالة(0 . . •) ، وللتأكد من اتجاه الفروق قام الباحث بإجر اء حسـساب المقارنــات المتعددة فجاءت النتائج على النحو التالي:

$$
\text { جدول (T) }
$$

يوضتح نتائج حساب المقارنات المتعددة

\begin{tabular}{|c|c|c|c|}
\hline القيمة الاحتمالية & الخطأ المعياري & متوسط الفروق & العو امل \\
\hline,$\cdots$ & r,orv & $r_{1, \Lambda}$ & القياس القبلي- التكويني \\
\hline,$\cdots$ & $r, T \leqslant 1$ & $\varepsilon, \uparrow \wedge \Lambda-$ & القياس القبلي__البعدي \\
\hline,$\cdots$ & $r, 090$ & 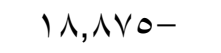 & القياس التكويني-البعدي \\
\hline
\end{tabular}

ويتضـح من الجدول السابق وجود فروق دالــة إحــصائيًا عنــد مـستوى دلالة(ه . . •) بين القياس القبلي و التكويني لصالح التكويني. ووجود فروق دالــة إحصائيًا عند مستوى دلالة(0 . . ) بين القياس القبلي و البعدي لصالح البعـدي، 
كما اتضح وجود فروق دالة إحصائياً عند مستوى دلالـــة(0. . •) بــين القيــاس

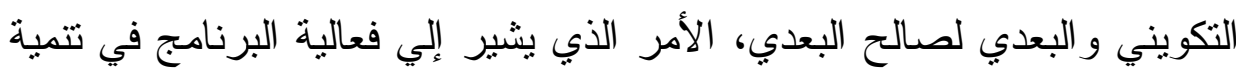
اللغة لدى الأطفال المضطربين لغيًا بحسب بطاقة الملاحظة.

\section{مناقثة نتيجة الفرض الأول والثاني معاً:}

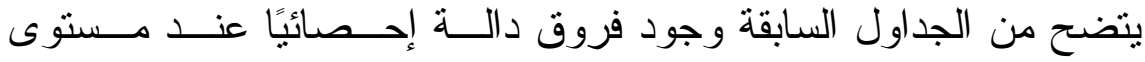
دلالة(0. . •) بين منوسطات درجات الاضطر اب اللغوي على القياسات المتعددة

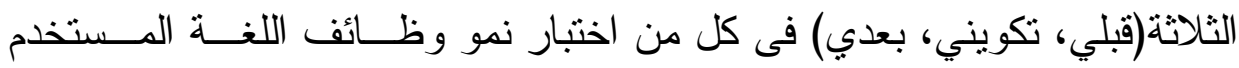
وبطاقة الملاحظة لصالح القياس التكويني عنه في القياس القبلي و القياس البعدي

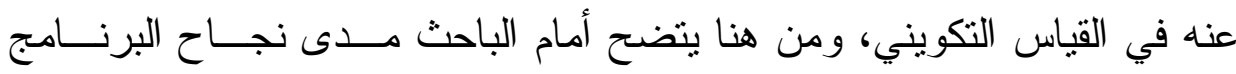

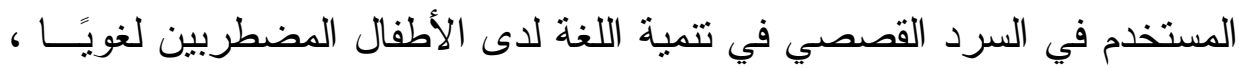

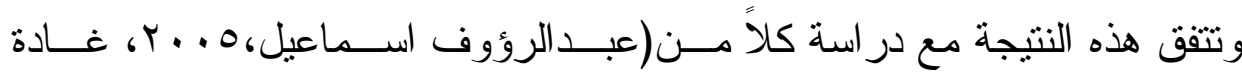

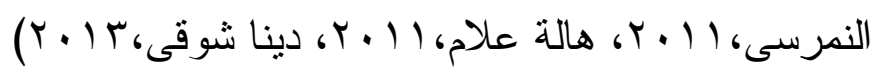
ويرجع الباحث نجاح البرنامج المستخدم الي تصميمه وفقا لمجموعة مسن الأسس النفسية و التربوية وهو ددعم بفنيات علاجية و التي يتطلبها تتمية الكفاهيم

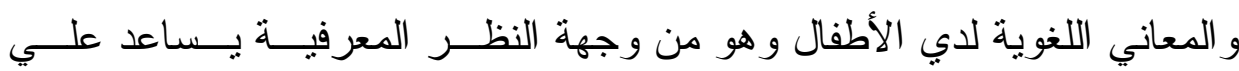
الانتقال من الأنشطة و الألعاب اللغوية ( السرد القصصي ، الصور مالفية ، الأغــاني )

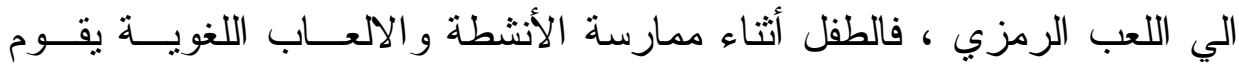
بتكر ار الأفعال وإستدعاء صور ذهنية ، ويتصور ويتذكر ويفكر فضلا عن قيامه الإها

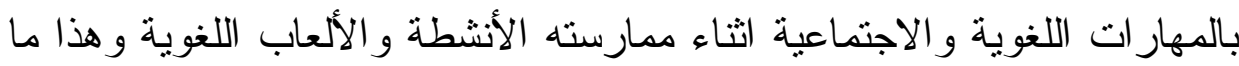

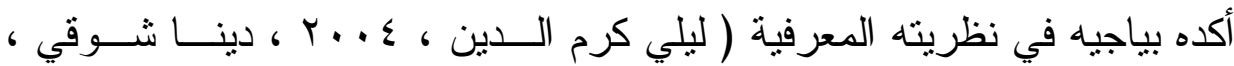
• (Rubin, 2005 , Oral , M , 2012 ، r. Ir 
ويرجع الباحث نجاح البرنامج أيضا الي أنــهـ راع أن تكــون الأنـشطة

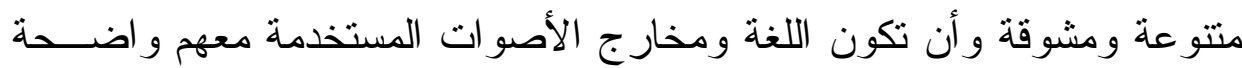

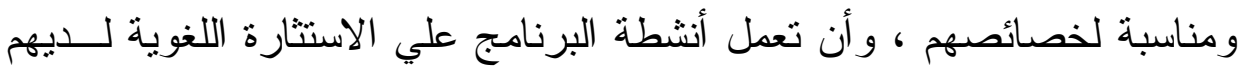

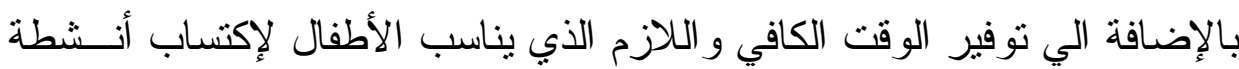

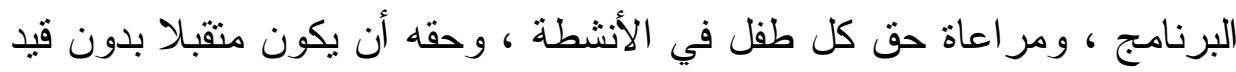

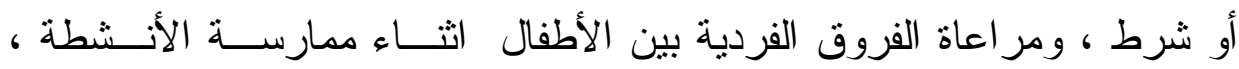

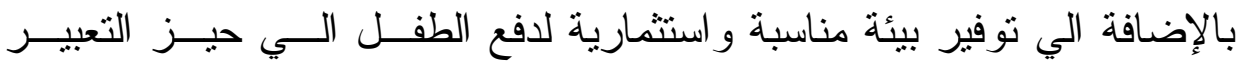

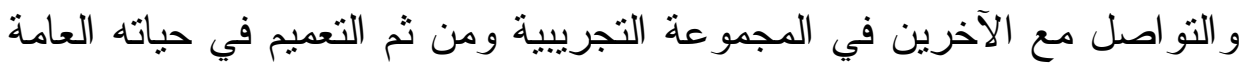

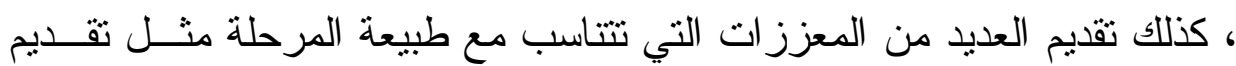

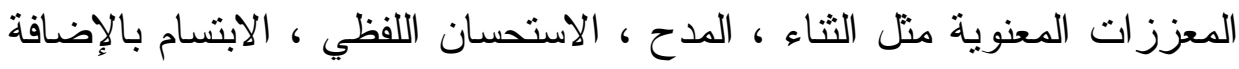

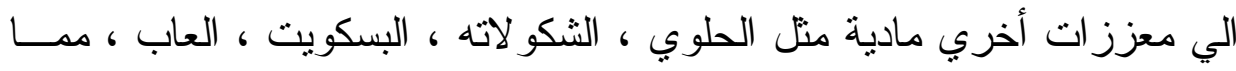

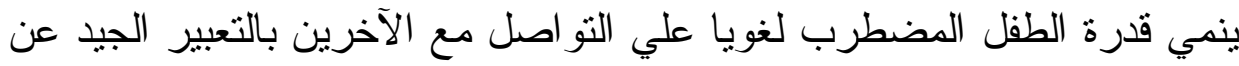

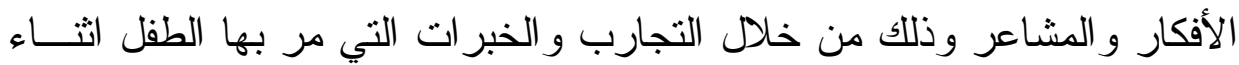

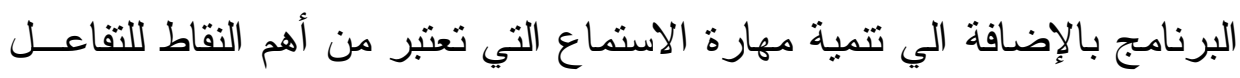

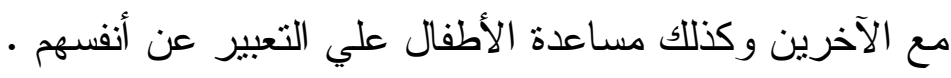
فالنشاط القصصي من الأنشطة المحببة للأطفال ، و القريب من نفوسـهم ،

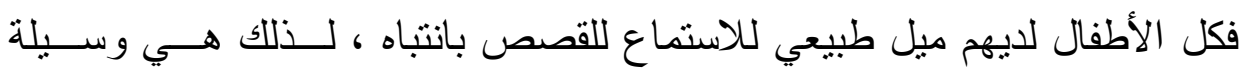

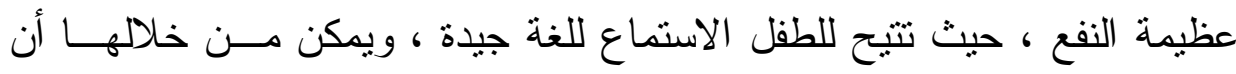

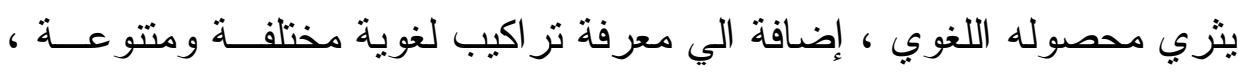

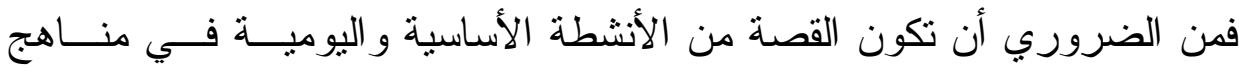

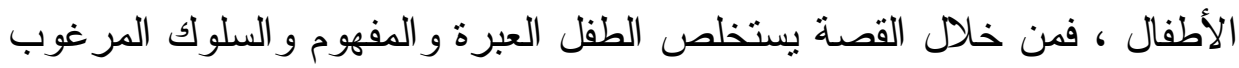

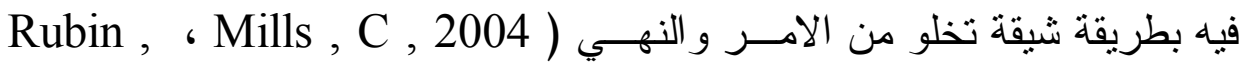




\section{عرض نتيجة الفرض الثالث:}

لاختبار صحة الفرض الثالث الذي ينص على (يوجـــــــأثير لمتغيــر

الجنس علي الفروق في القياسات المتعددة (قبلي، تكويني، بعدي) لدى الأطفــال المضطربين لغويا فى إختبار نمو وظائف اللغة ) ، قام الباحث بحسـساب تحليـلـل

التباين للقياسات المتعددة (Multivariate Repeated Measures)

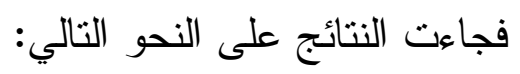

$$
\text { جلول (؛ }
$$

يوضح المعالم الاحصائية للقياسات المتعدة لمتغير الجنس

على اختبار نمو وظائف اللغة

\begin{tabular}{|c|c|c|c|c|c|}
\hline الاحتمالية & نسبة & الحرجية & قيمة f & sig قيمة & التأثير \\
\hline,$\leqslant \wedge \wedge$ & $\wedge, \cdots$ & $r, \cdots$ &,$\vee \wedge \wedge$ & דז & اختبار و الكس لمبادا \\
\hline
\end{tabular}

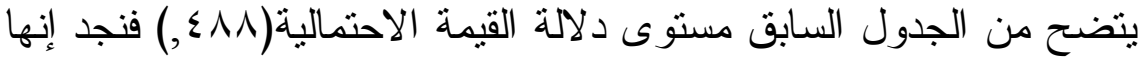

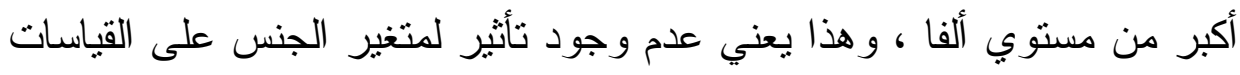
المتعددة الثلاثة في إختبار نمو وظائف اللغة تبعاً للجنس.

يمكن تفسير هذه النتيجة في ضوء أسباب اجتماعية؛ حيث تشجع الأسـرة

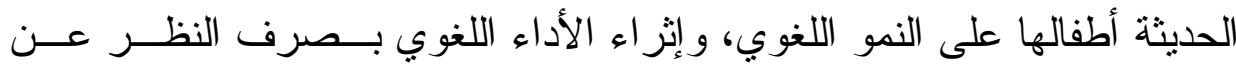

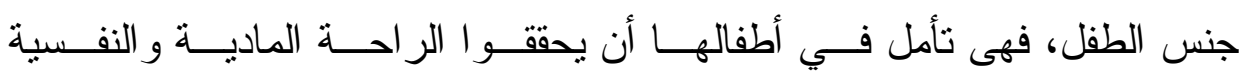

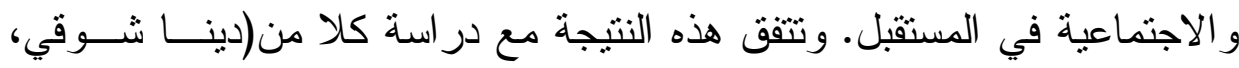

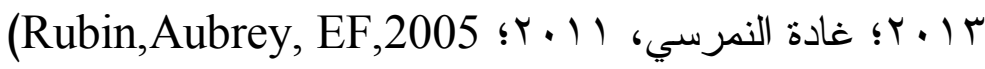




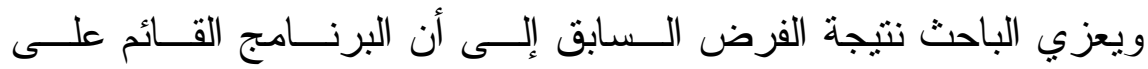

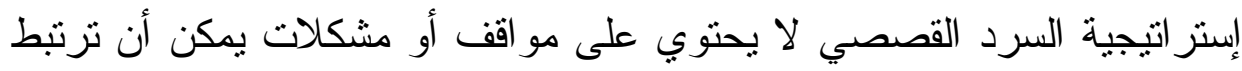

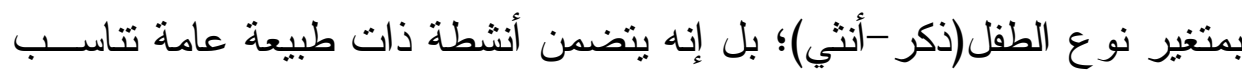

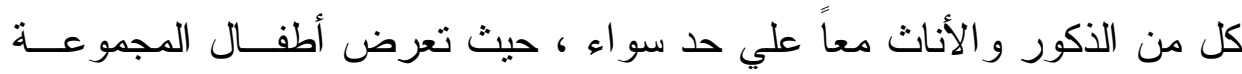

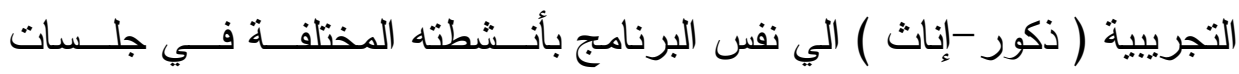

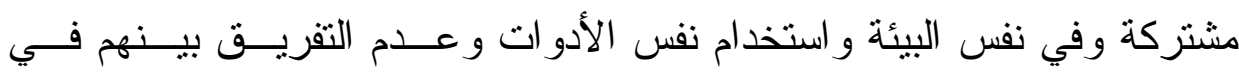
الأنشطة بل راع الباحث المساو اة في تعرضهم جميعا لفنيات و أنشطة البرنامج • فالنشاط القصصي مهم جدا في مرحلة الروضة لكل من الذكور و الانــاث

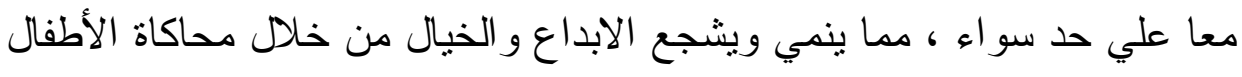

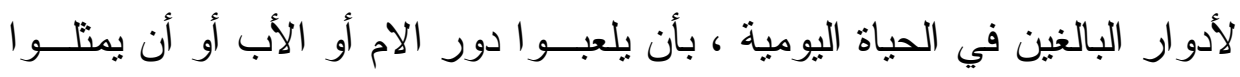

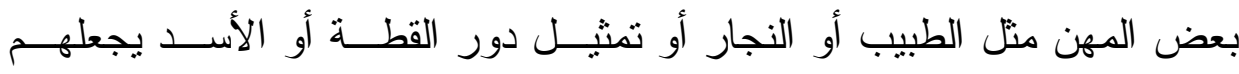

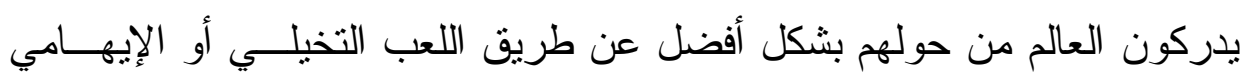

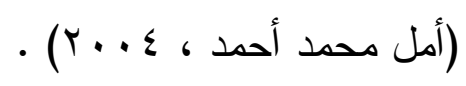

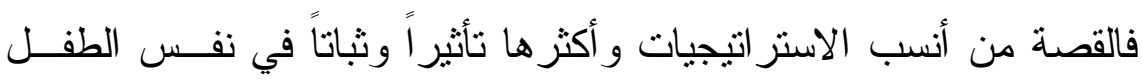

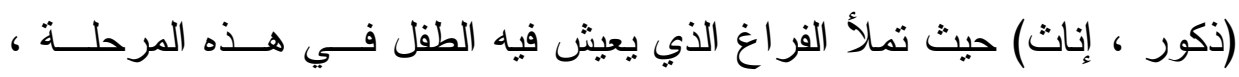

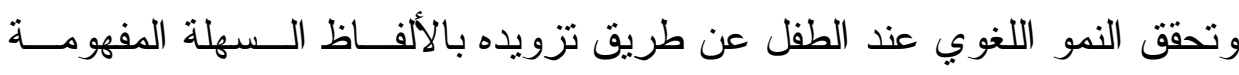

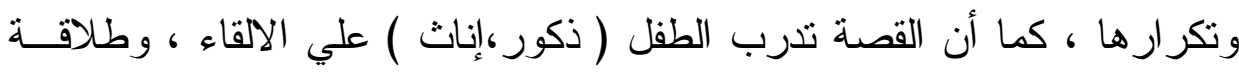

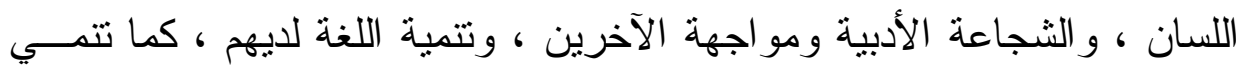

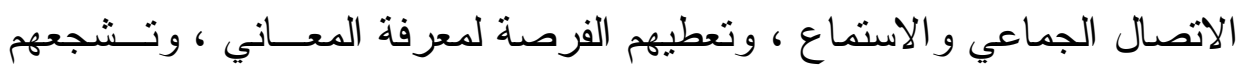

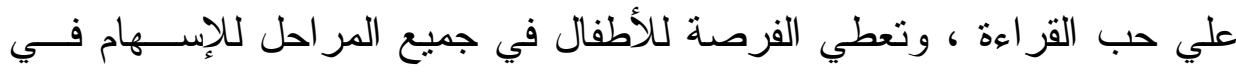

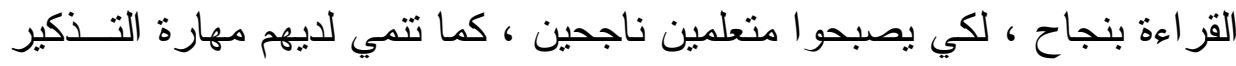

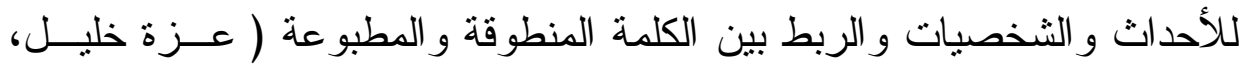

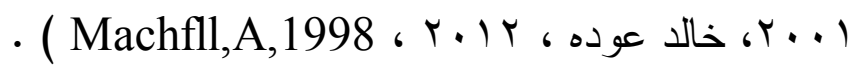




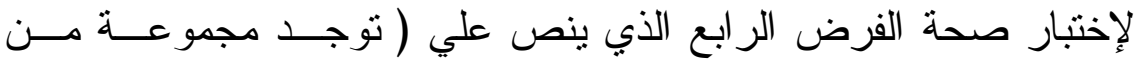
العو امل الدينامية المسئولة عن الإستفادة أو عدم الإستفادة من البرنامج ). و لإختبار صحة هذا الفرض استخدم الباحسـث دراســة الحالــة ، وذلـــك للكثف عن أهم العوامل المسببة في العوامل الدينامية المؤثزة علي النمو اللغوي ، وقام الباحث بتحديد حالة من أطفال الدجموعة التجريبية في القياس التكـــيني

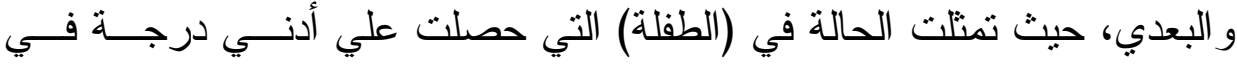

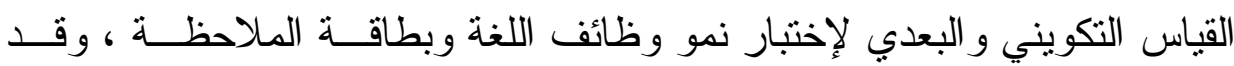

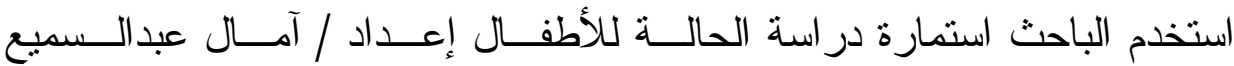

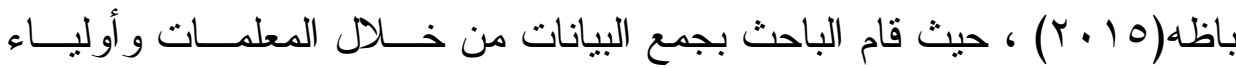

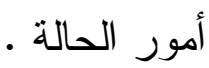

\section{نتائج دراسة الحالة مع بعض أفراد العينة :}

تعد در اسة الحالة مكمل للبرنامج التنريبي لما تضيفه عليه مــن و اقعيــة وتكوين صورة واضحة عن أفر اد المجموعة التجريبية قبل وبعد تطبيق البرنامج

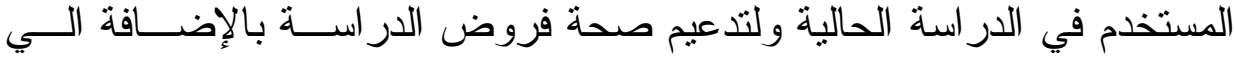
أدو ات القياس المستخدمة في الدر اسة ـ الراسلة

أولا / بيانات شخصية

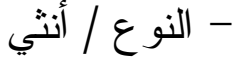

$$
\begin{aligned}
& \text { - المستوي التعليمي / حضانة حكومي } \\
& \text { - السن / (0) سنوات الكني السيكي }
\end{aligned}
$$




$$
\begin{aligned}
& \text { - عدد أفر اد الأسرة / خمسة أفر اد } \\
& \text { - عدد الأخوة و الأخو ات / أخ و أخت الت التراه } \\
& \text { - عمل الأب / موظف في احدي البنوك } \\
& \text { - عمل الأم / ربة منزل معل الأب }
\end{aligned}
$$

ثانيا / التشخيص

تم تشخيص الحالة من خلال حصولها علي درجات منخفضة فى القيــاس القبلى على بطاقة الملاحظة و علي مقياس نمو وظائف اللغــة ، إعـــداد / نهلـــة

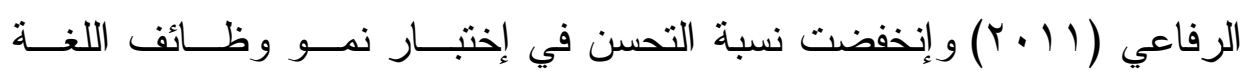
وبطاقة الملاحظة بعد تطبيق البرنامج القائم علي السرد القصــصي و الأنـشطة المصاحبة له عن الأطفال الآخرين فى المجموعة التجريبية فى القياس التكـــينى

$$
\text { و البعدى. }
$$

ثالثاً / سلوك الطقلة داخل الحضانة وخارجها

داخل الحضانة : كانت الطفلة تعاني من صعوبات في التفكير و القــــراءة ،

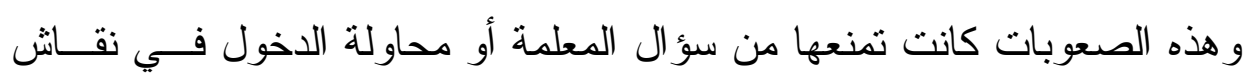

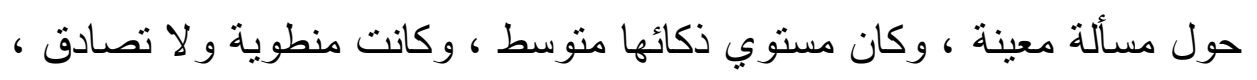

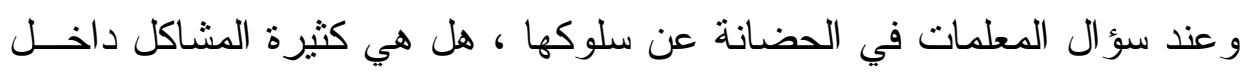

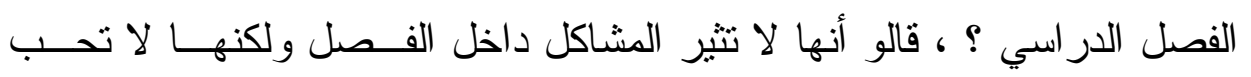

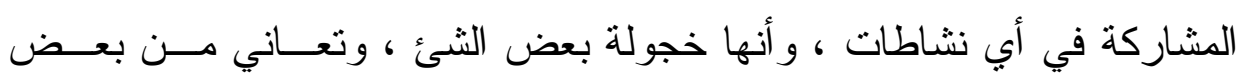

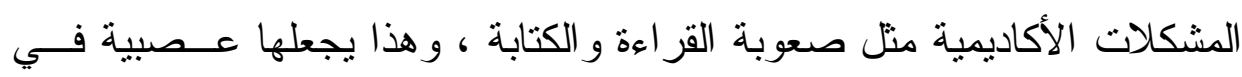

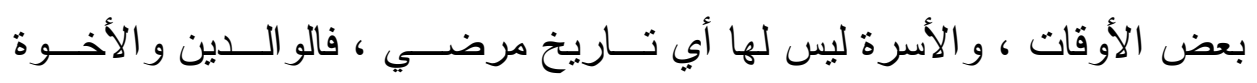

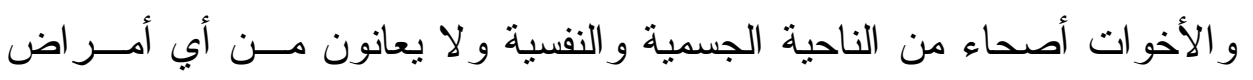


نفسية أو جسمية أو أي إعاقات أخري ، ويتنبي الاب مفهوم سلبي عن الإعاقــة

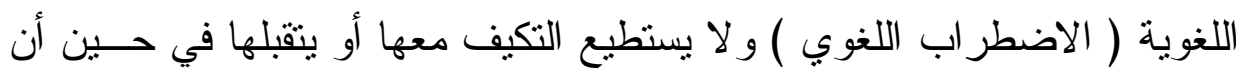

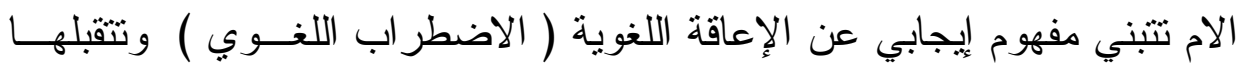

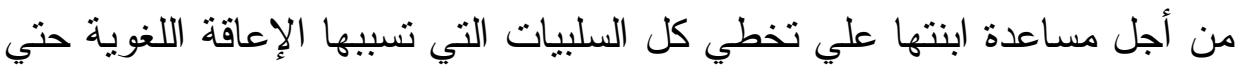

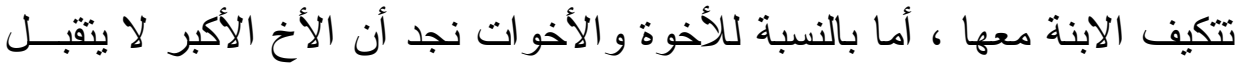

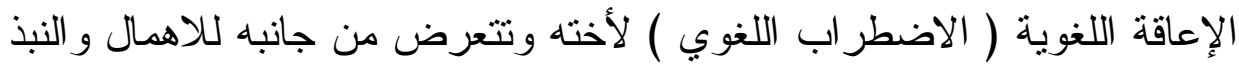

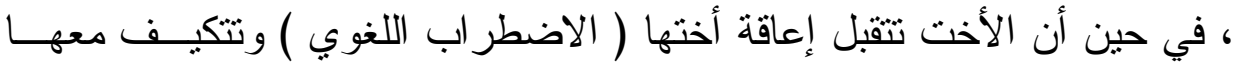
وتتعامل معها كما لو أنها شخص عادي ، وتعاني الطفلة ( الحالة ) من الإهـــال

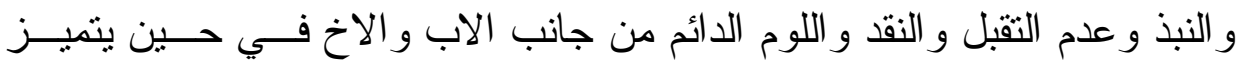

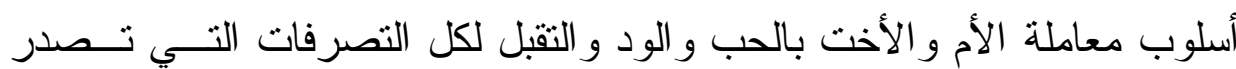

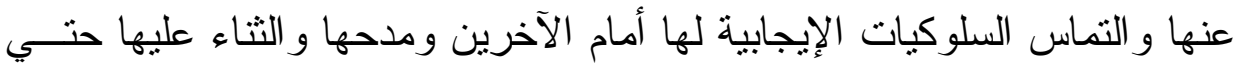
تنتز ع من نفسها أحاسيس الخوف و القلق .

\section{تحليل إستجابة الحالة من خلال استمارة دراسة الحالة:}

تعاني الطفلة من بعض المخاوف و أهمها الخوف من الاختلاط بــالآخرين و الغرباء ، وتميل الي الانسحاب من المو اقف الاجتماعية و المشاركة الاجتماعية

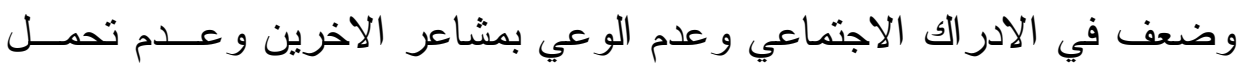

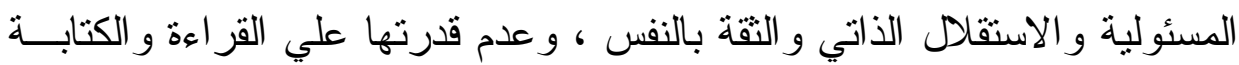

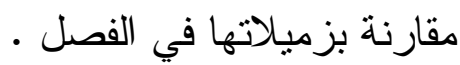

\section{تفسير نتيجة دراسة الحالة :}

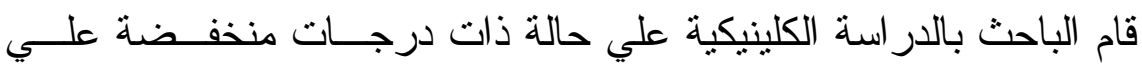
بطاقة الملاحظة واختبار نمو وظائف اللغة المستخدم في الدراسة الحالية ، وذلك 
بهدف الحصول علي أكبر قدر من المعلومات الخاصة بهــــه الحالــة ، وكـــللك تحديد البناء النفسي و العو امل الكامنة ور اء ذلك ، وقد كثفت الدر اسة الكلينيكيـــة عن مجموعة من العو امل تتمثل فيما يلي : 1- عدم تتجيع سبل الحو ار و المناقثة مع الطفل . r- عدم تثجيع الطفل علي مخالطة الآخرين و التو اصل معهم •

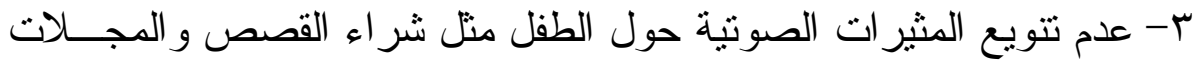

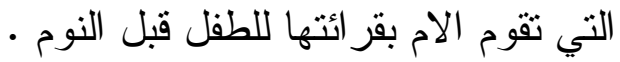
ع- عدم وجود البر امج التي تقوم علي تعديل اتجاهات المحيطين بالطفل الذي لأن

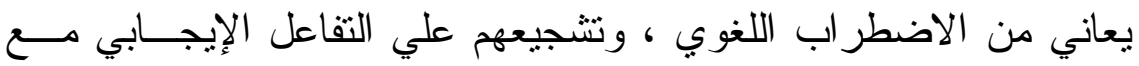

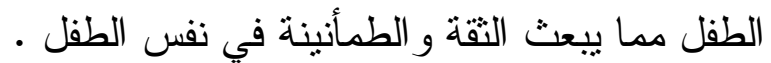
0- عدم تحفيز الاسرة للطفل علي التكلم بانتظام وتعلــم المفــردات اللغويـــة

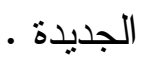
1- إستخدام أسلوب العقاب المعنوي وتوبيخ الطفل الدائم و المستمر يخلق حالة

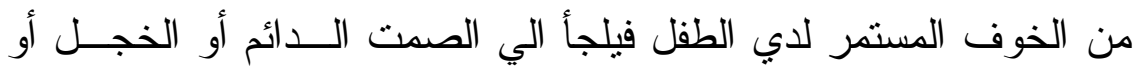

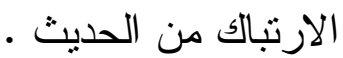
V- عدم قيام الاسرة بشرح وتبسيط الدفاهيم و العلاقات و المتز ادفات الجديــدة للطفل 1- عدم القيام بعمل دورات تدرييية ارشادية لأمهات و آباء ومعلمين هـؤُ لاء الأطفال وتدرييهم علي كيفية التعامل معهم . 9- عدم وجود البر امج التي تستتد الي الأنـشطة الجماعيــة و التــي تـساعد

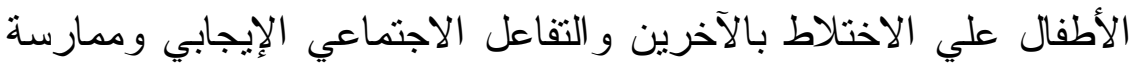

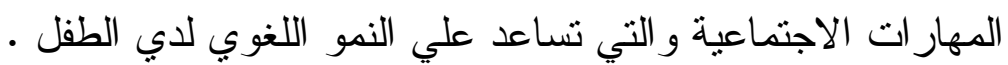




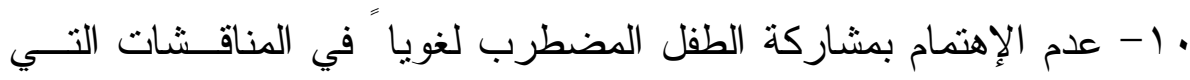

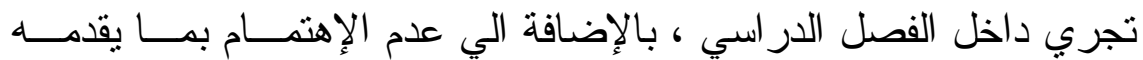

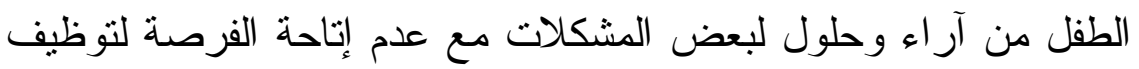

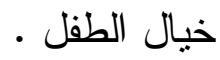

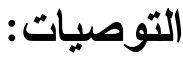

من خلال النتائج التى توصلت إليها الدر اسة الحالية، والتى تضمنت أثــر

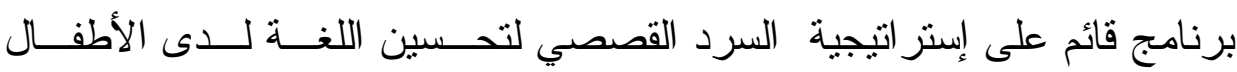
المضطربين لغوياً.

يقدم الباحث بعض النوصيات التزبوية النالية:

• أهمية التعرف على اضطر ابات اللغة التي يتعرض لها الأطفال في مرحلـــة الطفولة المبكرة و التعامل معها حتى لا تتفاقم فيما بعد. • •تثجيع سُبل الحوار و المناقثة مع الأطفال.

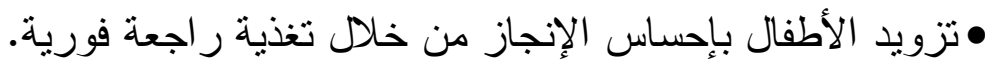

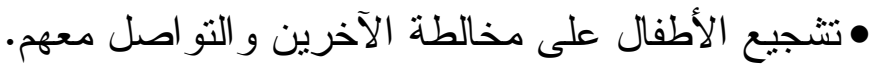
• أحياناً تكون المشكلات الكلامية للطفل ناتجة عن الخبرات المؤلمة النفــسية

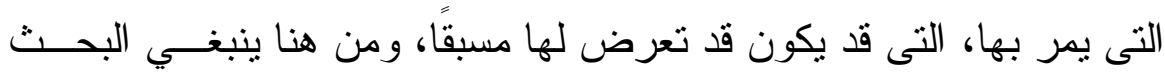
عن تلاك الضغوطات النفسية، و إز التها.

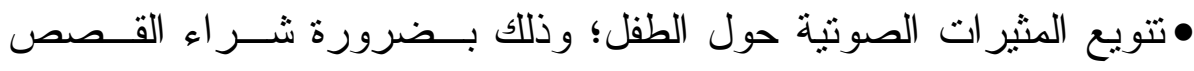
ومجلات تقوم الأم بقر اعتها لطفلها قبل النوم. • شر ح وتبسيط الدفاهيم و العلاقات و المتز ادفات الجديدة علي الطفل . •رو اية القصص للطفل وطلب سرد الاحداث وتسلسلها . 
• تحفيز الطفل علي التكلم بانتظام •

• الاستماع الي الطفل و الرد عليه بشكل طبيعي • • عمل دور ات تدرييية وارشادية لأمهات و آباء هؤلاء الأطفال وتدريبهم علي كيفية التعامل معهم - كورن • عمل دور ات ارشادية لمعلمات الروضة توضح لهـم خــصائص هـؤلاء الأطفال المضطربين لغويا و الطرق الصحيحة للتعامل معهم .

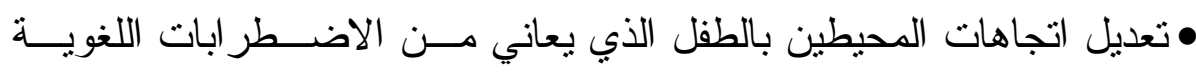
وتشجيعهم في التقاعل الإيجابي مع الطفل مما يبعث التقة و الطمأنينـــة فــي نفس الطفل • الإهنمام بمشاركة الأطفال المضطربين لغويا في المناقشات التـي تجــري داخل حجرة الدر اسة ، و الاهتمام بما يقدمونه مــن آر اء وحلــول لــبعض المشكلات مع اتاحة الفرصة لتوظيف خيال الأطفال . • إعطاء بر امج تربوية للمعلمين الذين يقومون بالتدريس لهذه الفئة لمساعدتهم

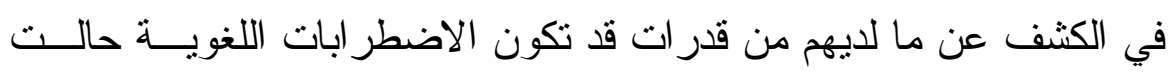
دون ظهور ها و العمل علي استثار وتتمية هذه القدر ات .

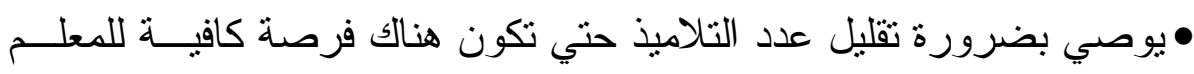
للاهتمام بهم ، وحتي لا تكبت القدرات الإبداعية وتضبيق المجال الادر اكي للطفل . • ضرورة الاهتمام بشخصية الطفل المضطرب لغويا و العمل علي نمو قدر اته و استعداداته وميوله و اتجاهاته بدلا من توجيه الاهتمام الز ائد بحشو أذهانـــه بالحقائق العلمية فقط . 


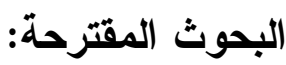

• در اسة إكلينكية لتتبع العو امل الكامنة ور اء الاضطر ابات اللغوية لأطفال مـــ

$$
\text { قبل المدرسة. }
$$

• استخدام قصص الأنبياء لتحسين المهارات اللغوية لدى الأطفال المتــأخرين لغويًا.

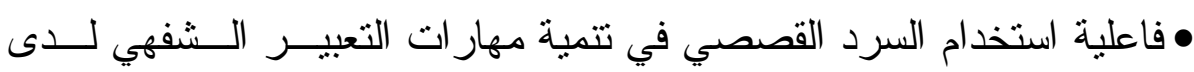
أطفال الروضة المضطربين لغويًا.

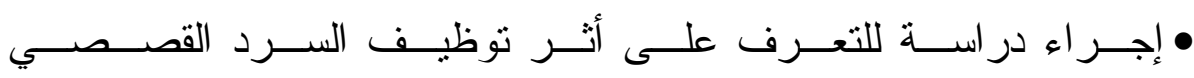

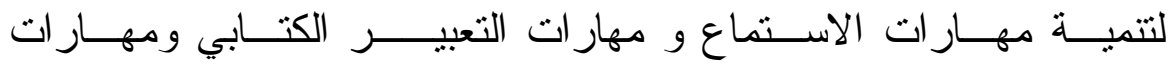
القر اءة الجهرية لاى الأطفال في مر احل در اسية متعددة.

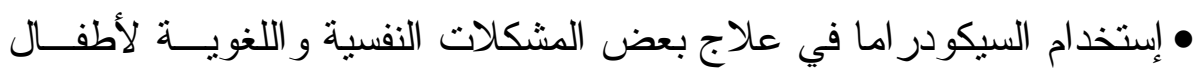
سن ما قبل الددرسة. 


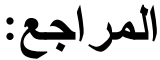 \\ أولاً : المراجع :}

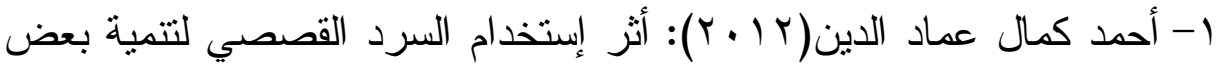

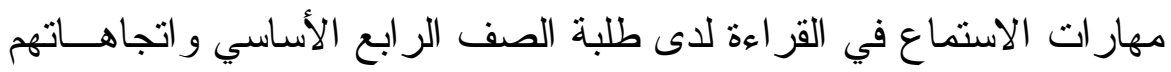
نحوها، رسالة ماجستير ، غير منشورة كلية التربية.

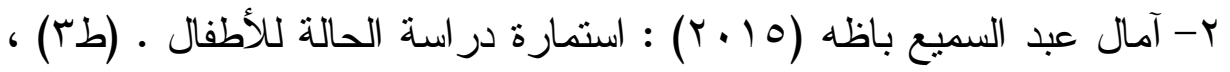

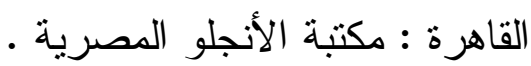

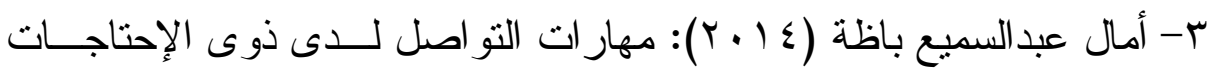
الخاصة (طץ)، القاهرة، مكتبة الأنجلو الدصرية.

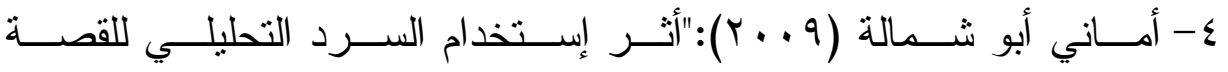

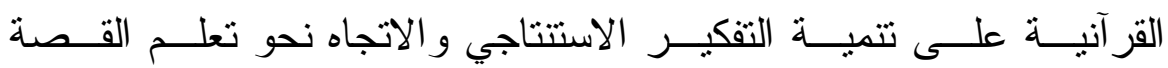

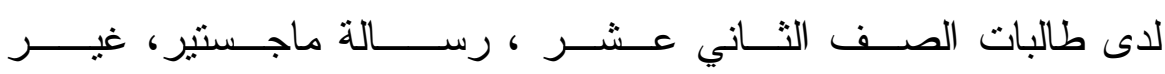
منثــورة ، الجامعة الإسلامية، غزة.

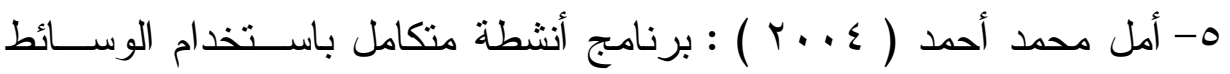
التكنولوجية لطفل الروضة وتقويمه بالبورتقليو ، رسالة دكتــور اه ، غيـر

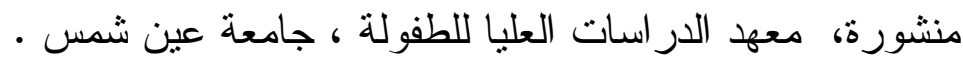

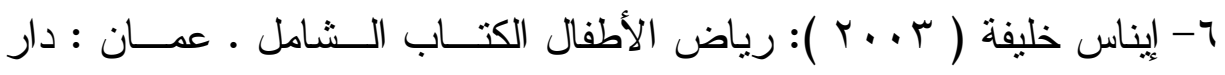

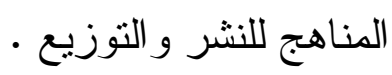

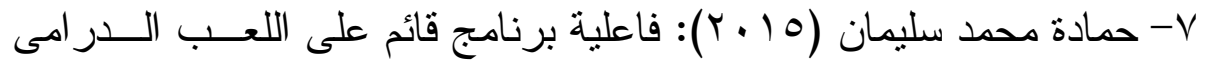

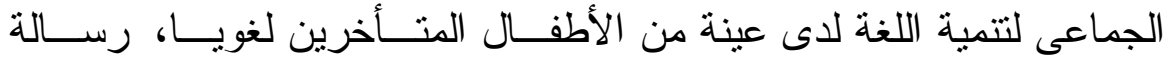
ماجستير، غير منشورة، كلية التربية، جامعة كفر الثنيخ. 


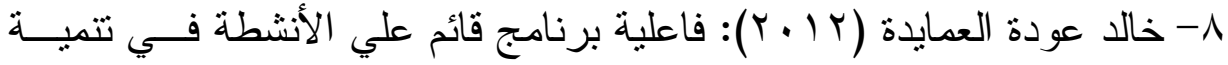

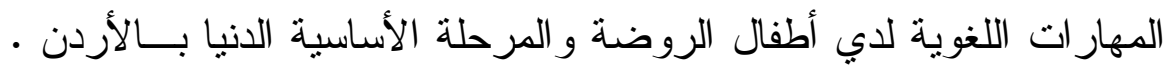
رسالة دكتور اه ، معهد الدر اسات و البحوث التزبوية ، جامعة القاهرة .

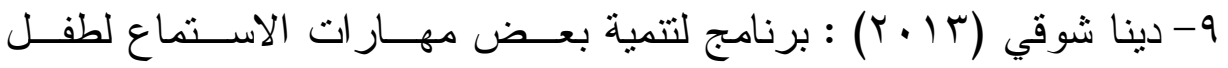
الروضة بإستخدام القصص ، رسالة ماجستير ، كليــة ريــاض الأطفــال:

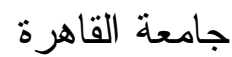

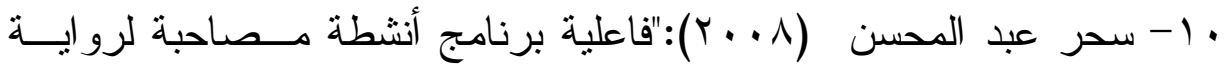

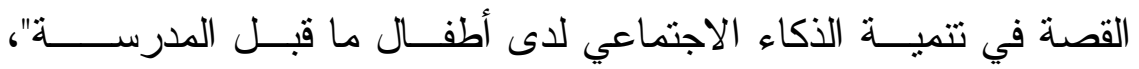

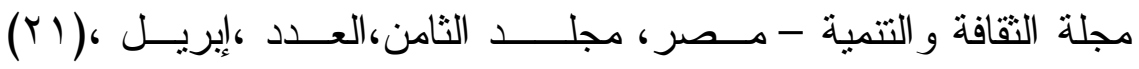

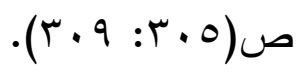

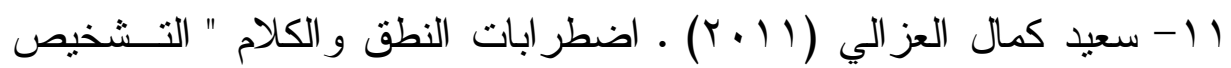

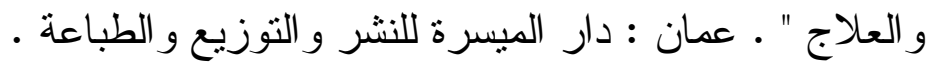

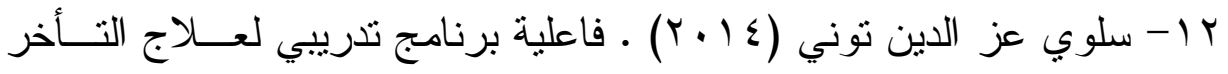

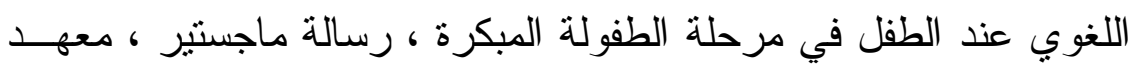
الدر اسات التزبوية : جامعة القاهرة .

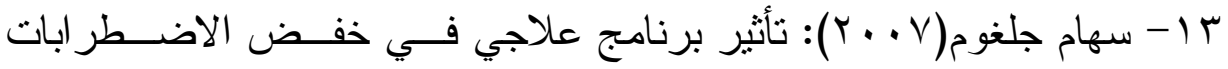

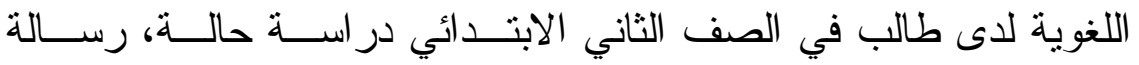
دكتور اه، كلية التزبية، الجامعة العربية المفتوحة، الأردن. الإن.

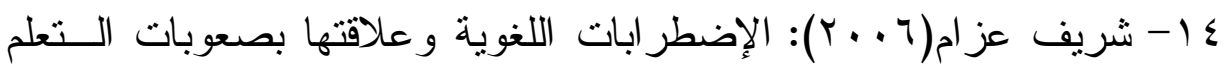
عند الأطفال، كلية التزبية، السعودية.

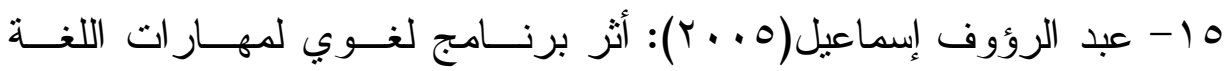
التعبيرية لدى الأطفال من ذوي الإضطر ابات اللغوية، رســالة دكتــور اة، غير منشورة، كلية المعلمين، جامعة الملك سعود. 


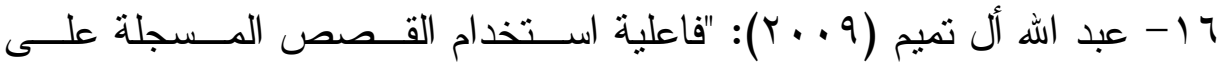

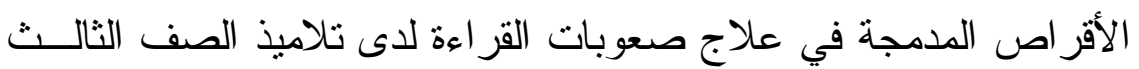

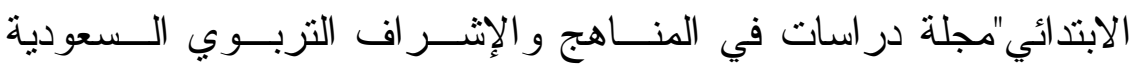

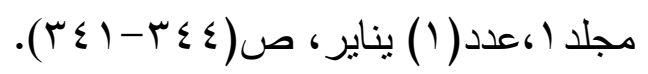

IV الإقتصادى للأسرة (طץ)، القاهرة، مكتبة الأنجلو المصرية.

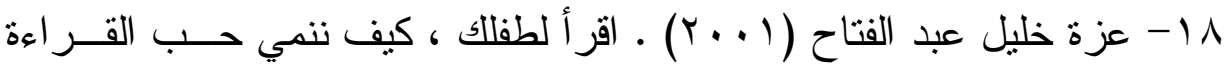

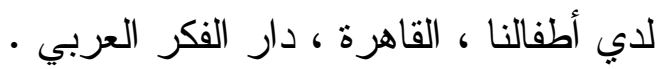

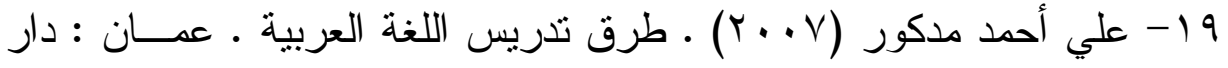

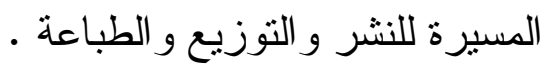

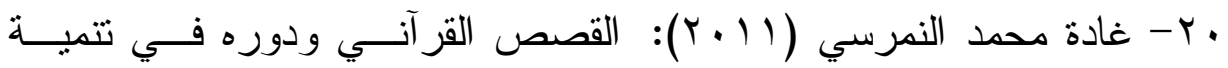
مهار ات اللغة عند الأطفال، رسالة ماجستير، غير منشورة ، كلية التزبيـــة للآداب و العلوم التربوية، جامعة عين شمس.

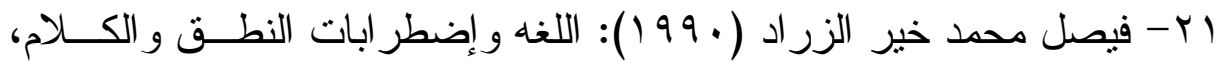

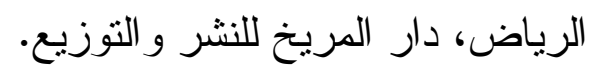

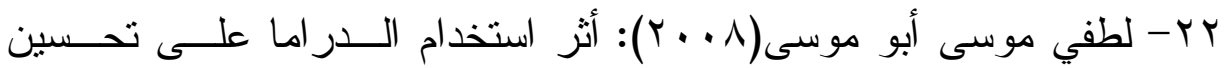

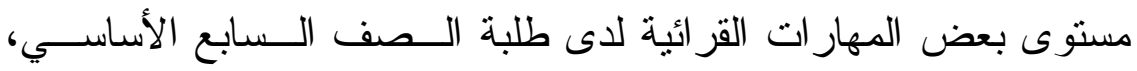

رسالة ماجستير، غير منشورة ، كلية التزبية، الجامعة الإسلامية، غزة.

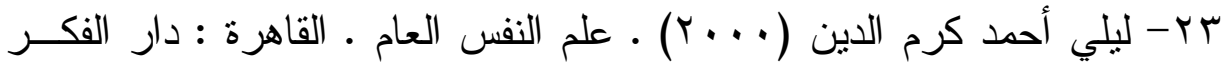

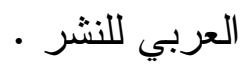

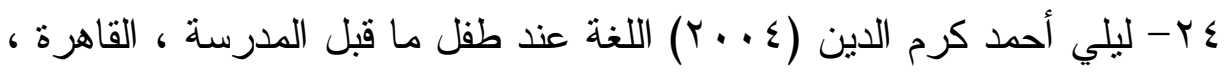

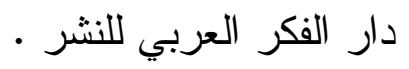




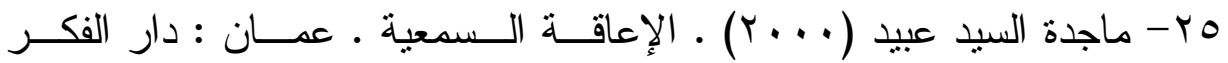

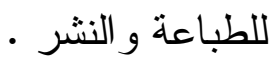

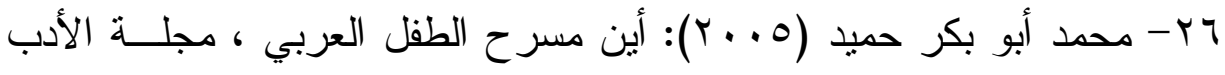

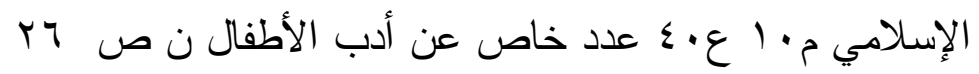

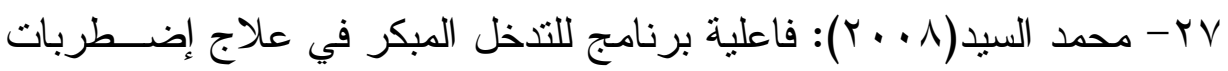

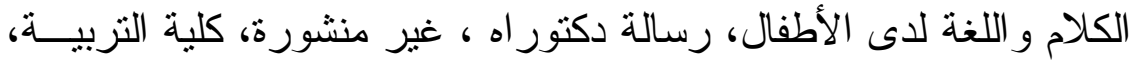
جامعة عين شمس.

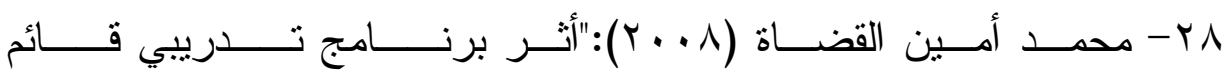

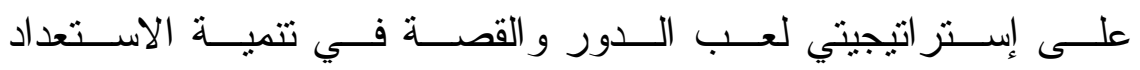

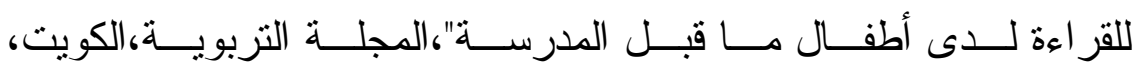

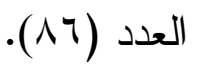

9ץ- محمد طه، عبد الموجود عبد السميع (1) (1) ـ مقياس ستانفورد - بينيه

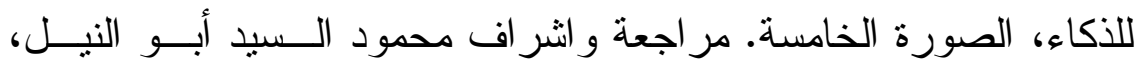

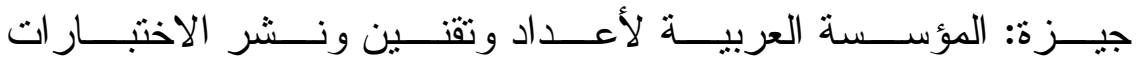
النفسية .

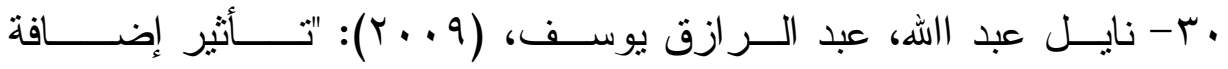

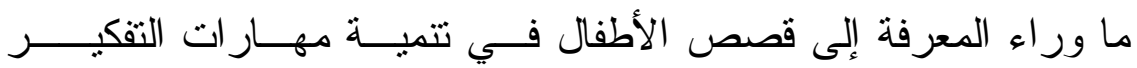

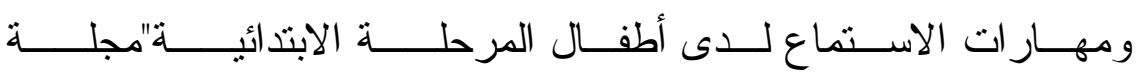

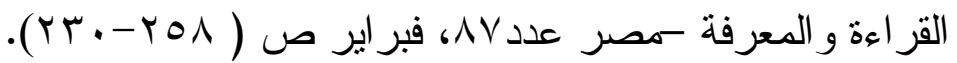

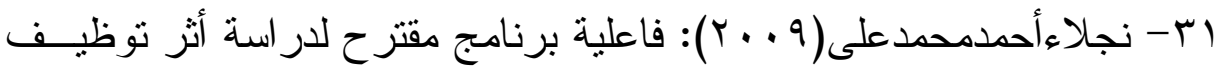

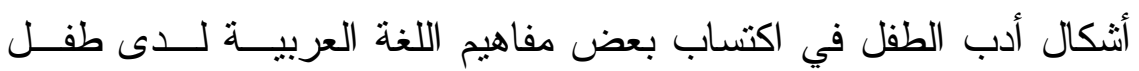
الروضة، رسالة ماجستير،غير منشور ، كلية التربية، جامعة الاسكندرية. 


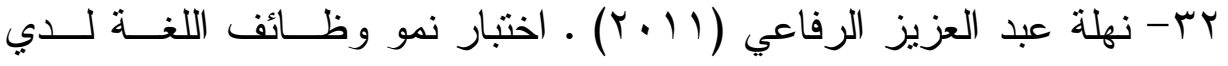

$$
\begin{aligned}
& \text { الأطفال ، الصورة المعدلة ـ القاهرة : مكتبة الانجلو المصرية . }
\end{aligned}
$$

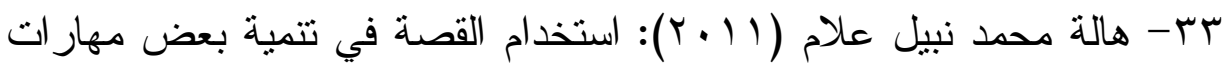

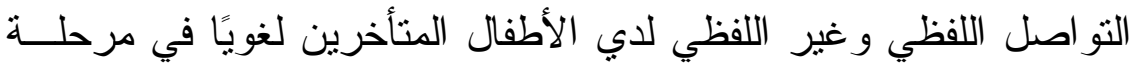

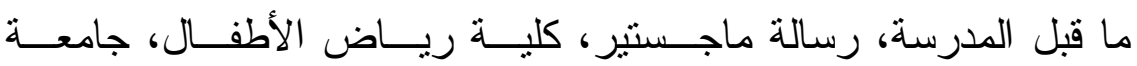

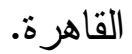

34- Abbey,N.(2009). Using Play Intervention to Improve the Skills of Children with Language Delay, The Degree of Master, United States : University of Nebraska .

35- Asha, (1994): Language Disorder. Asha, 36(10), PP237240

36- Bridge,B.(2010) Children and Langauge Development, retrieved From www.aboat.com Last retrieved in $10 / 3 / 2015$.

37- Demirel,m.(2010). Primary school curriculum for educable mentally retarded children ,A Turkish case. USA- china Education Review,7(3), 64-91.

38- Fritz, C. O, Morris,P.E \& Richler,J.J.,(2012) .Effect size estimates : Current use, Calculations, and interpretation : Journal of Experimental Psycology,141(1), 2-18 .

39- Games, L.(2009) .21st Century Language and Literacy gamestar mechanic middle school student,appropriation

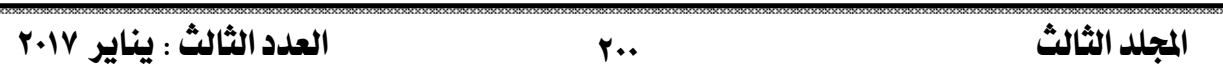


through play of the discourses of computer games designers ", the Degree of Doctor, United States : University of Wisconsin - Madison .

40- Laura,J (2007) Social and Behavioral characteristics of preschooler with specific Language impairment,Lorie skibbetracilgrant, united states : University of Virginia .

41- Machfall, A.(1998). Telling Story " What Children Know and feel about Literature. Black well Puplshers, Reading Journal .

42- Mills, C.(2004). Effect of working Memory and Presentation Condition on narrative production and inference skillsin childrenwith Language - Learning impairments,PHD the University of Tennesse Knot Ville

43- Oral, M.(2012). Explaining Suicide : The Role of Drama . University of Queen Belfast . Vol.15.N.5.PP.14-17.

44- Paul,M,Robert, Y .,Toby, Q., David, M., Rob, J, \& Ann, L.(2011) Early Intervention for at risk children : 3 years Follow Up. University of New Castle.PP.111-120 .

45- Rubin, Aubrey, EF(2005):"Auditory input therapy using a story to treat articulation disorders" vol (44) ,No(1)Dissertation Abstracts international, p34. 
46- Smith, Deborah,(2004). Introduction to Special Education, Teacing In An Age of opportunity ,5th Ed, by Mattie Stepanek, USA.

47- Weis, M. ( 2007) Increasing Receptive Expressive and Overall Language Skills in Language Delayed Preschool Studentthe Degree of Doctor, United States : Nova Southeastern University .

48- William yule and orlee udwin (2003): "imaginative play in language disordered children", Vol (18), No(3), pages(197-205).

49- Yosra , M, (2011). Prevalence of Subtypes of specific Language Impairmen, Master of Phoniartics, Cairo : University of Ain Shames . 


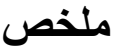

أثز ممارسة السرد القصصي لتحسين اللغة لاي

أطفال الروضة المضطربين لغوياً

د / سعد عبد المطلب عبد الغفار **

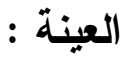

تشتمل عينة الدر اسة علي مجموعة مــن الأطفــال المــضطربين لغويــاً

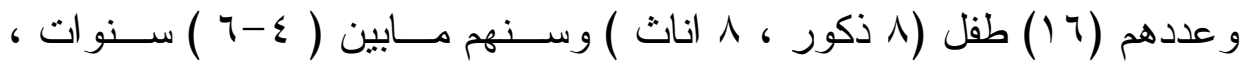

ونتر اوح نسبة ذكائهم ما بين ( .9- • (1 ) وجميعهم من روضة هابي كيـدز -

المنصورة - الدقهلية

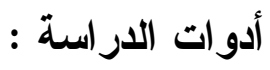

اختار الباحث أدوات لنتاسب عينة الدر اسة وهـــي مقيــاس ســنانفورد -

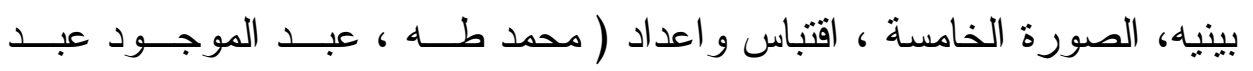

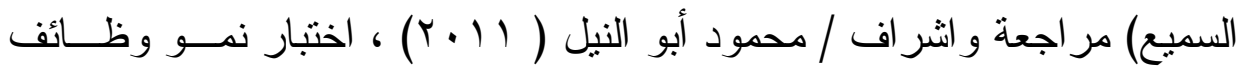

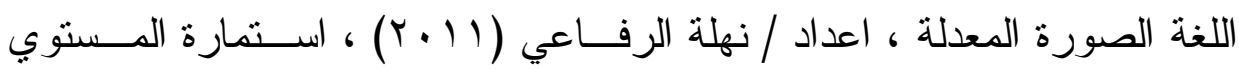
الاجتماعي الاقتصادي لعبد العزيز الثخص ( ع ( ب) ، بطاقة الملاحظـــة مــن

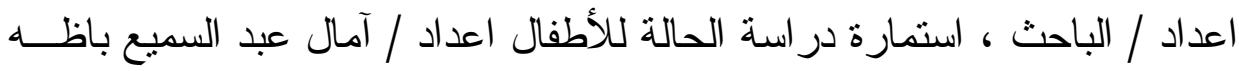
(0 ( 10) ، البرنامج القائم علي السرد القصصي اعداد / الباحث .

* مدرس علم النفس. كليت رياض الأطفالـ جامعت المنصورة 


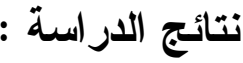

يوجد فروق دالة إحصائيًاً بين القياس القبلي و التكـــيني لاختبـــار نــــو

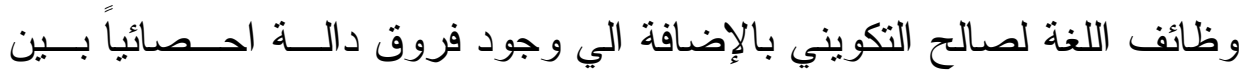
القياس التكويني و البعدي لاختبار نمو وظائف اللغة لصالح البعـدي ، ووجــود

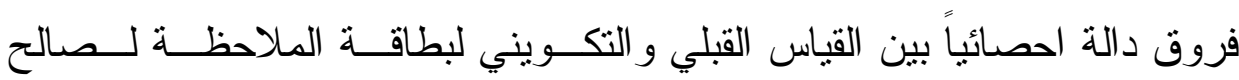

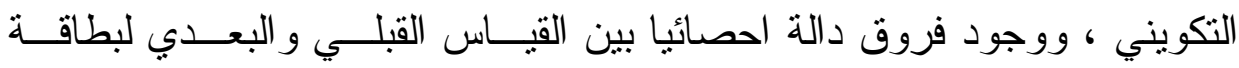

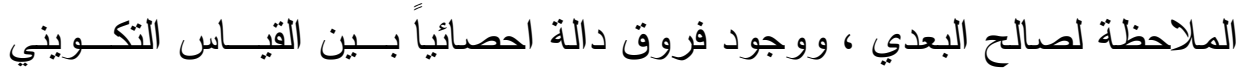

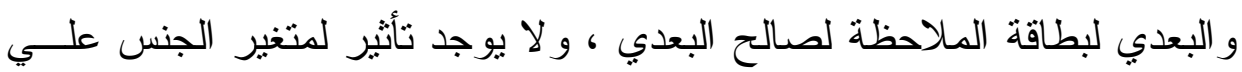

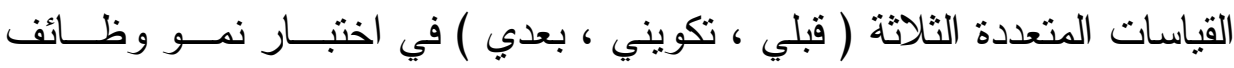

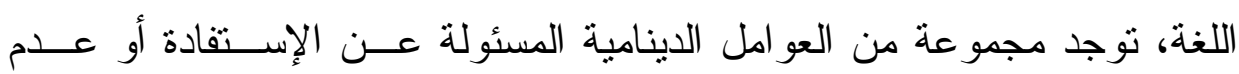
الإستفادة من البرنامج وفقا لنتائج در اسة الحالة التى توصل إليها الباحث. 


\section{$\underline{\text { Abstract }}$}

\section{The effect of storytelling on improving language for articulation disorder kindergarten children}

\section{Dr. Saad Abdul Muttalib Abdul Ghaffar Abdul Muti*}

\section{Sample}

The study sample consisted of 16 articulation disorder children ( 8 males, 8 females) and their age ranges from (4-6) years, and their Intelligence quotient ranges from (90-110). All samples were taken from Happy Kids Kindergarten Mansoura - Dakahlia.

\section{Study Tools:}

The researcher chose tools so as to suit the sample of the study, namely the Stanford-Bennett Scale, the fifth picture, the quotation and the preparation of (Mohamed Taha, Abdelmawjood Abdel Samie), revision and supervision of Mahmoud Abou El Nil (2011). Growth testing of language functions, modified image, prepared by Nahla Rifai (2011). The Social Economic Level Questionnaire prepared by Abdulaziz Alshakhs (2014). Observation card, prepared by the researcher. Case study form for children, prepared by / Amal Abdel Samie ABaza (2015). The program based on storytelling, prepared by the researcher.

* Professor of psychology, Kindergarten College, Mansoura University

\begin{tabular}{|c|c|}
\hline العدد الثالث : نيار YlV & r.0 \\
\hline
\end{tabular}




\section{Results}

There were statistically significant differences between the pre-test and the formative evaluation of the growth of the language functions in favor of the formative test. In addition to that, there are statistically significant differences between the formative and the post-test for the growth of the

functions of the language in favor of the post test. There are statistically significant differences between pretest and the formative for observation card; the results are for the formative. There are statistically significant differences between the pre and post test for observation card in favor of the formative. There are statistically significant differences between the formative and posttest of the observation card in favor of the posttest. There are no statistically significant differences between the formative and posttest of observation card for favor of posttest. There is no effect of the gender variable on the three different measurements (pretest- formative- and posttest) in testing the growth of language functions, there is a set of dynamic factors which are responsible for benefiting or not benefiting from the program according to the results of the case study that the researcher reached to.

\footnotetext{
العدد الثالث : يناير r.lV
} 